Final Report for the Arroyo Las Positas Maintenance Impact

Study, Lawrence Livermore National Laboratory

M. van Hattem, L. Paterson 
This work was performed under the auspices of the U.S. Department of Energy by University of California, Lawrence Livermore National Laboratory under Contract W-7405-Eng-48. 


\section{Table of Contents}

INTRODUCTION AND BACKGROUND SUMMARY .................................................... 1

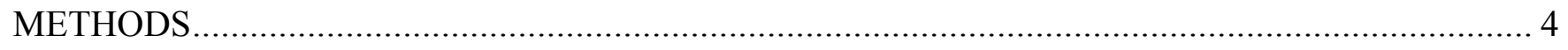

California red-legged frog (R. a. draytonii) Population Monitoring.............................................. 4

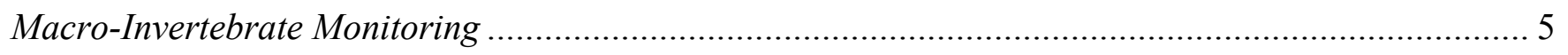

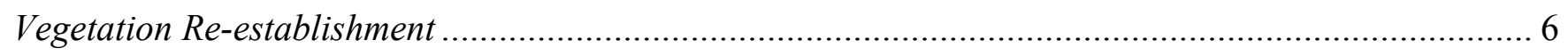

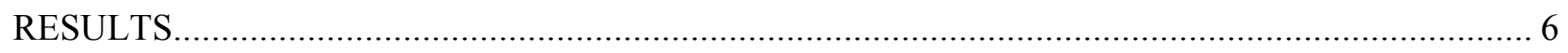

California red-legged frog (R. a. draytonii) Population Monitoring ............................................ 6

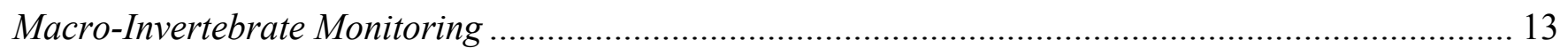

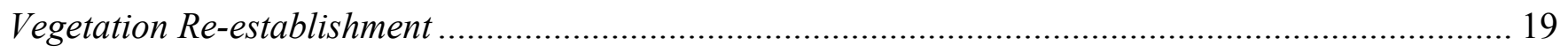

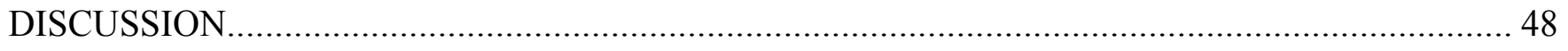

California red-legged frog (R. a. draytonii) Population Monitoring .............................................. 48

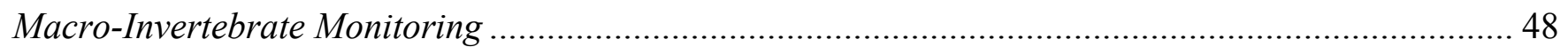

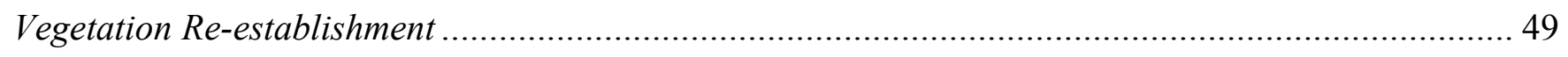

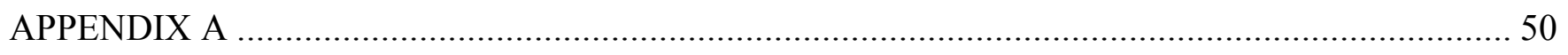

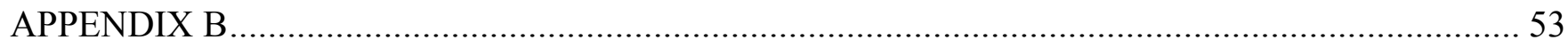




\title{
Final Report for the Arroyo Las Positas Maintenance Impact Study Lawrence Livermore National Laboratory
}

\author{
January 2006
}

\section{Introduction and Background Summary}

In 2000, the Lawrence Livermore National Laboratory's (LLNL) Environmental Protection Department, in coordination with Plant Engineering (PE), began dredging sections of the Arroyo Las Positas (ALP) to alleviate concerns about flooding of sensitive facilities within the mainsite of Lawrence Livermore National Laboratory.

In order to reduce potential impacts on the federally threatened California red-legged frog (Rana aurora draytonii), LLNL proposed to dredge sections of the ALP in a "checkerboard pattern," resulting in a mosaic of open water habitat and vegetated sections (Figure 1). The Arroyo Las Positas Management Plan (Plan) was coordinated with both state and federal agencies including the U.S. Fish and Wildlife Service (USFWS), California Department of Fish and Game (CDF\&G), San Francisco Regional Water Quality Control Board (SFRWQCB), and the Army Corp of Engineers (ACOE).

Water Discharge Requirements (WDRs) were issued for this project on December 30, 1999 (Order No. 99-086) by the SFRWQCB. Provision 19 of the WDRs outlined a five-year (2000 through 2004) Maintenance Impact Study (MIS) that LLNL began in coordination with dredging work that was conducted as part of the Arroyo Las Positas Management Plan.

Provision 20 of these WDRs requires LLNL to submit a final report of the results of the Maintenance Impact Study for this project to the SFRWQCB. The purpose of this report is to present the results of the Maintenance Impact Study for Arroyo Las Positas and meet the requirements of Provision 20. A description of the annual monitoring included in this Maintenance Impact Study is included in the methods section of this report.

Initially the Plan called for dredging the entire length of the Arroyo Las Positas (approximately 6,981 linear feet) over a 5-year period to minimize temporal impacts on the California red-legged frog. Dredging occurred in 2000 ( 1,300 ft.), 2001 ( $\sim 800 \mathrm{ft}$.), and $2002(\sim 1,200 \mathrm{ft}$.), which constituted approximately 3,300 ft., or roughly half of the entire Plan (Figure 2). Logistical challenges and unanticipated cost influenced the decision to terminate the project prior to completion, and re-evaluate the long-term management goals for the ALP. No dredging was conducted in the final two years of the plan (2003 and 2004). 


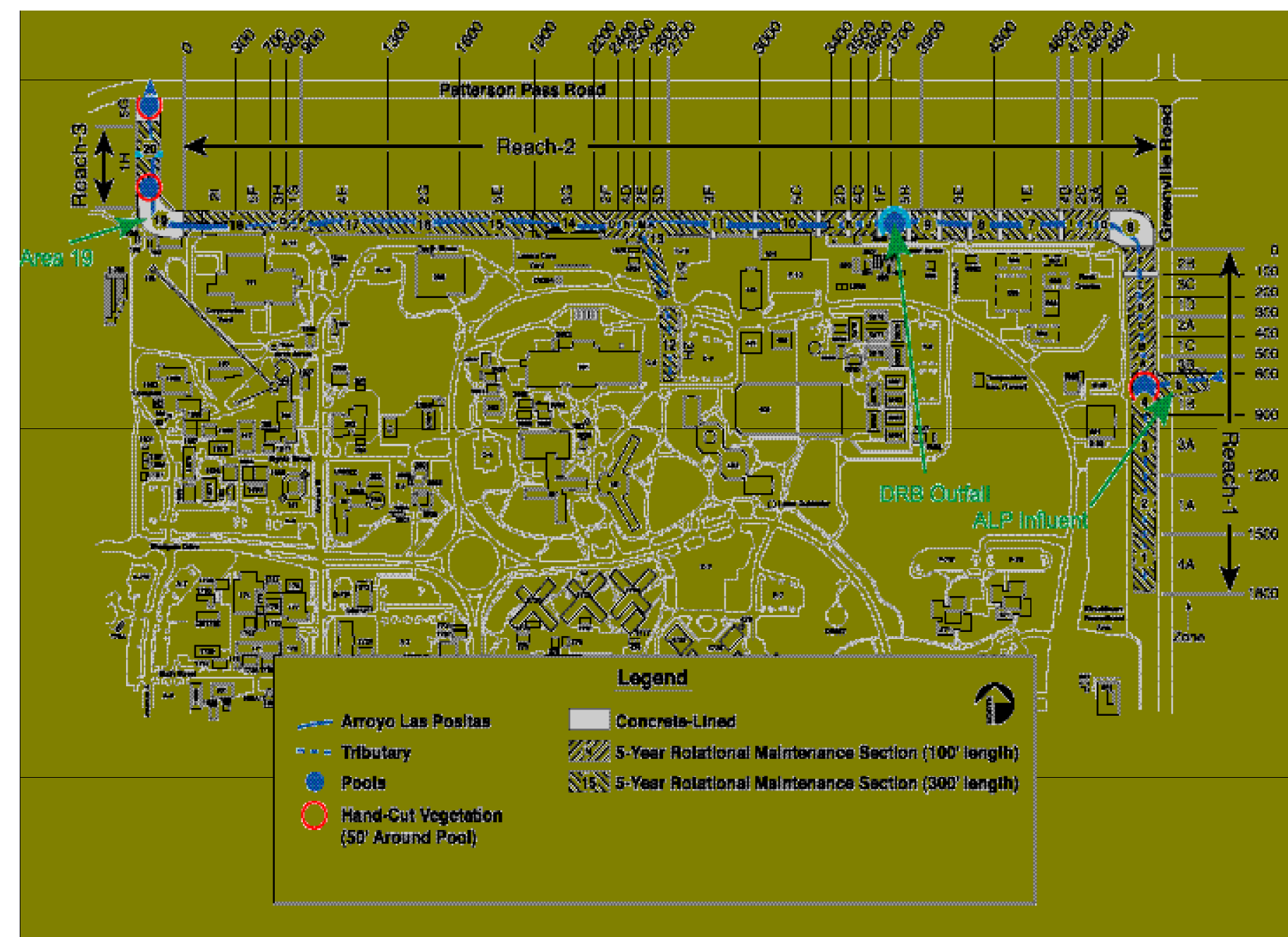

Figure 1. The Arroyo Las Positas (ALP) enters the Livermore mainsite in Reach 1, flows north and then west (Reach 2), and exits LLNL property to the north (Reach 3), and constitutes approximately 6,981 linear feet. The Arroyo Las Positas Management Plan called for de-silting 100-foot and 300-foot sections of the ALP in a "checkerboard pattern" to reduce temporal impacts on California redlegged frogs. 


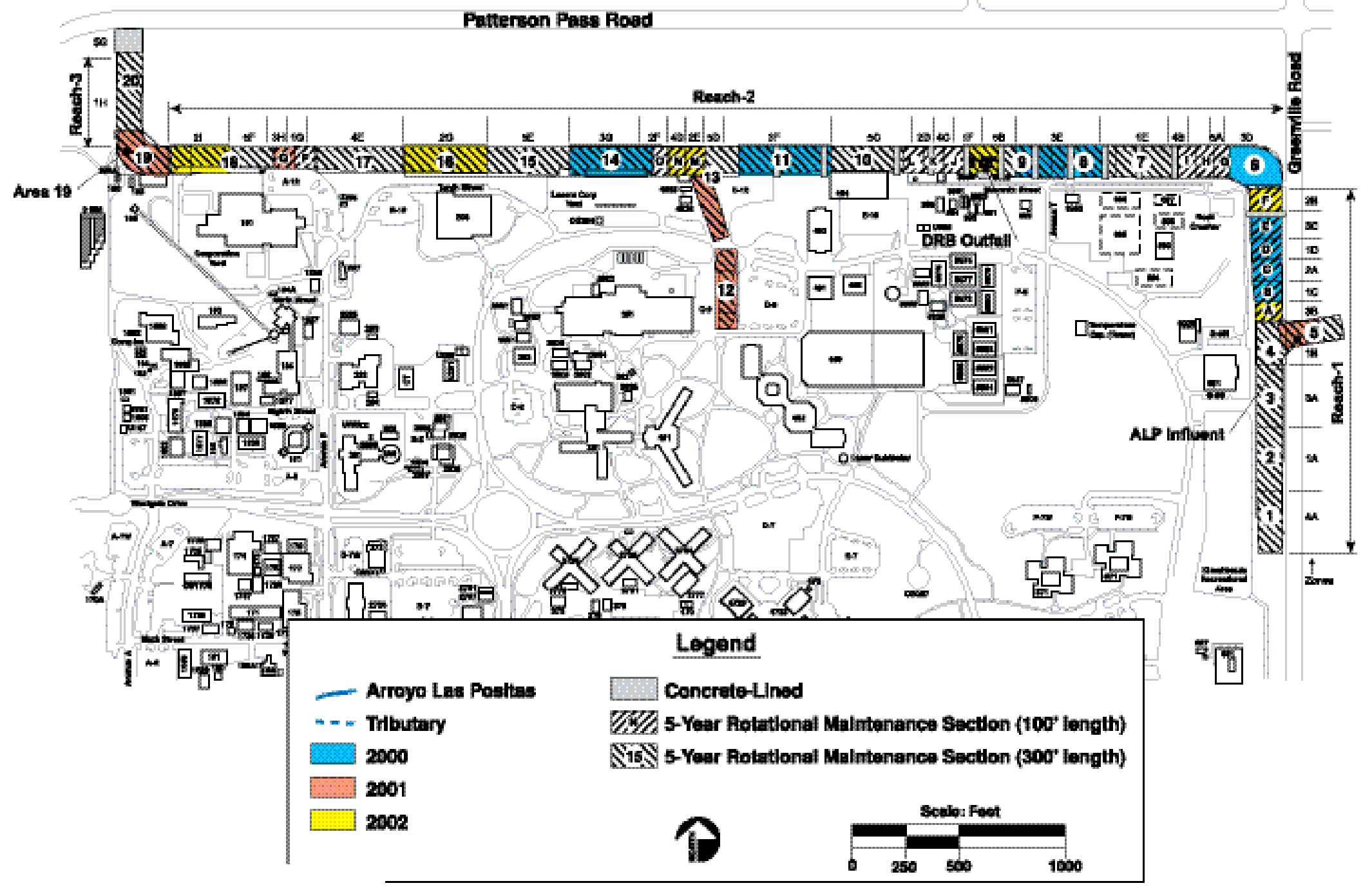

Figure 2. Dredging of the Arroyo Las Positas occurred in 2000 ( 1,300 ft.), 2001 ( 800 ft.), and $2002(\sim 1,200 \mathrm{ft}$.), which constituted approximately $3,300 \mathrm{ft}$., or roughly half of the entire Plan. 


\section{Methods}

The Maintenance Impact Study for the Arroyo Las Positas Maintenance Project was based on elements of permit provision 19 relating to monitoring wildlife and habitat changes relative to the Arroyo Las Positas Maintenance Project.

Provision 19 of the Waste Discharge Requirement (WDR) states:

"The Discharger shall submit a Final Plan, acceptable to the Executive Officer, for the Maintenance Impact Study (Study) no later than June 1, 2000. The Plan shall include a detailed description of the proposed annual monitoring, including: assessments of $R$. a. draytonii presence and distribution; macroinvertebrate species richness; and vegetation colonization and establishment. At a minimum, the plan shall include provisions for:

a. R. a. draytonii monitoring, including seasonal nocturnal surveys;

b. Macro-invertebrate monitoring, including pre- and post-activity sampling in each of the areas desilted and in a control location; and,

c. Wetland vegetation establishment, including a comparison of annual growth and species diversity."

The Final Plan for the Maintenance Impact Study was submitted to the SFRWQCB on May 23, 2000. The following methodology elaborates on the Final Maintenance Impact Study that was developed from the outline in Provision 19. The Final Plan for the Maintenance Impact Study description is included in Appendix A.

\section{R. a. draytonii Population Monitoring}

To determine adult $R$. a. draytonii breeding presence (distribution) and activity levels in the LLNL portion of the Arroyo Las Positas, we conducted diurnal, two-person visual surveys during calm weather to locate $R$. a. draytonii egg masses. Surveys were conducted in March 2001-2004 and required 1-2 days to thoroughly search the entire study reach. The entire LLNL reach of Arroyo Las Positas was surveyed for egg masses each year.

We visually searched all suitable habitat with polarized sunglasses and close focus binoculars. Surveyors slowly and deliberately walked upstream, one individual per bank, just beyond the wetted stream margin, visually inspecting both the near-center and far margins of the stream. If visibility was impeded by emergent vegetation, then the plants were temporarily parted to allow for close inspection.

Wading was not required for any portion of the survey. Once an egg mass was encountered, a series of biotic and abiotic parameters were quantified. For each egg mass encountered, the following parameters were measured: distance from shore, distance from surface, vertical depth of the water column, and the location of egg mass attachment. During 2003 and 2004, we also sampled the vegetation surrounding each egg mass. Specific cover estimates were taken from $1-\mathrm{m}^{2}$ quadrats $(1.3 \mathrm{~cm}$ diameter PVC plastic with $30 \mathrm{~cm}$ legs on each corner) centered on each egg mass. Cover estimates include plant species and other features above the water level. Estimates did not include any aquatic vegetation or subsurface features. 


\section{Macro-Invertebrate Monitoring}

Macro-invertebrates were collected using a $900 \mu \mathrm{m} 18$ " W x18" L aquatic kick net in each of three primary maintenance zones $(3 \mathrm{G}, 3 \mathrm{~F}$, and $3 \mathrm{E})$, and the control zone $(1 \mathrm{H})$. Zones $3 \mathrm{G}, 3 \mathrm{~F}$ and $3 \mathrm{E}$ were all dredged in the initial year of the project (2000). Aquatic invertebrates were collected using a sweeping/pulsing motion over a square meter. Net contents were then sorted, and plant and organic matter were removed. Macro-invertebrates were identified to the family level.

The MIS for the Arroyo Las Positas maintenance project called for macro-invertebrate sampling starting in the year 2000 and ending in the year 2004 with dip-net samples taken within 30 days prior to maintenance activities, and between thirty and sixty days after the maintenance activity. Subsequent macro-invertebrate sampling would occur annually in late spring. This schedule was followed with the exception of 2004. Samples were collected in June 2000, October 2000, June 2001, October 2001, August 2003, and August 2005. No sampling occurred in 2004. Instead, an additional year of sampling occurred in 2005. We feel that this does not impact the result of the Maintenance Impact Study because no dredging has occurred in the LLNL reach of Arroyo Las Positas since 2002.

The following section is provided as an introduction to interpreting aquatic macro-invertebrate sample results. A variety of data measures have been developed to assess the stream health using aquatic macro-invertebrates.

Benthic macro-invertebrates are important elements of water quality evaluations because they (1) live in, on, or near streambed sediments; (2) have relatively long life cycles; and (3) are relatively sessile compared with larger organisms, such as fish. This combination of characteristics ensures that benthic invertebrates (1) respond to natural and anthropogenic environmental conditions that physical or chemically alter streambed sediments; (2) integrate effects over a year; and (3) characterize effects over a relatively small spatial scale (in contrast with fish, which may travel long distances). These factors make benthic invertebrates well suited for use in assessing site-specific water quality and comparing spatial patterns of water quality at multiple sites, and for integrating effects up to a year after a pollution or disturbance event.

The occurrence of benthic invertebrates in a stream is a response to natural and anthropogenic influences. Rivers naturally change as they flow downstream. Riparian vegetation conditions, light, temperature, hydraulics, and substrate composition all change and in response to these environmental changes benthic invertebrate communities change. Thus, each location in a river has a range of environmental conditions that dictate which invertebrate species are found there.

Abundance - The abundance, density, or number of aquatic macro-invertebrates per unit area is an indicator of habitat availability and fish food abundance. Abundance may be reduced or increased depending on the type of impact or pollutant. Increased organic enrichment typically causes large increases in abundance of pollution tolerant taxa. High flows, increases in fine sediment, or the presence of toxic substances or other anthropogenic impacts normally cause a decrease in invertebrate abundance.

Number of taxonomic families - All families are separated and counted. The number of families normally decreases with decreasing water quality. 


\section{Vegetation Re-establishment}

Prior to dredging (Zones 3G, 3F, 3E, and 3C including 1D, 2A, and 1C) in 2000, photographs were taken at the upstream and downstream limit of each zone. Post-dredging photographs were taken in subsequent years typically in late spring through fall. From the photographs, dominant vegetation types were determined and vegetative changes over time were recorded. A paper card was held in each photo for organizational purposes showing date, orientation, zone, reach, and in some cases when dredging occurred. A brief description of the plant communities in each zone and a list of dominant species were recorded prior to dredging in 2000.

\section{Results}

\section{R. a. draytonii Population Monitoring}

We observed and quantified 37 egg masses in 2001, 32 in 2002, 31 in 2003, and 9 in 2004. Reported values are means \pm SD. Figure 3 shows the distribution of California red-legged frog egg masses in the LLNL reach of Arroyo Las Positas during the winter and early spring of 2001 through 2004. Oviposition sites tended to be shallow $(22.86 \mathrm{~cm} \pm 9.40 \mathrm{~cm})$, and all egg masses were located in water shallower than $50 \mathrm{~cm}$ (Figure 4). Most egg masses were within one meter of the shore $(65.29 \mathrm{~cm} \pm$ $40.75)$ and near the surface $(3.90 \mathrm{~cm} \pm 6.25 \mathrm{~cm})$. Egg masses were usually deposited on vegetation that provided structure and to a lesser extent rigidity, such as attached inflorescence (Cyperus and Rumex), but unattached debris such as downed branches and decomposing vegetations were also used for oviposition (Figure 5).

Most $1-\mathrm{m}^{2}$ quadrats centered on egg masses included a portion of the stream bank and a portion of the hydrated stream channel, as a result cover estimates include emergent wetland species that occur in the stream channel, and upland and facultative wetland species that occur on the banks of the stream just above the water level (Figure 6). Egg masses were located in areas with $64.0 \% \pm 17.9 \%$ cover of open water. Grasses and emergent wetland species covered similar percentage of the quadrats (Table 1). The most common species were the exotic grass Echinochloa crus-galli $(6.0 \pm 13.3 \%$ cover $)$ and two emergent wetland species Cyperus eragrostis (5.6 $\pm 10.7 \%$ cover) and Rorippa nasturtium-aquaticum $(6.6 \pm 12.1 \%$ cover $)$. One tree species, Salix exigua, was found in the vegetation quadrats. S. exigua was only found near three of the 39 egg masses located in Arroyo Las Positas in 2003 and 2004.

The most noticeable change in California red-legged frog egg mass distribution occurred in Reach 1. In 2001 and 2002 combined there were 20 egg masses in Reach 1. Dredging conducted in the summer of 2002 allowed water to more freely drain from Reach 1 and as a result, water has not ponded in this area in the depths and durations needed for California red-legged frog breeding. Only one California redlegged frog egg mass has been observed in this area since 2002. Alternatively, egg masses were observed in Reach 3 in 2003 and 2004, but not in 2001 and 2002. 
Egg masses were found in breeding pools in Reach 2 throughout the study. As anticipated, breeding primarily occurred in areas where dredging created open pools preferred by California red-legged frogs for breeding. For example, the breeding pool in Zone 2G was used each year from 2001 through 2004 despite dredging in 2002. Also, the pool in Zone 3F, where dredging occurred in the summer of 2000, was used for breeding throughout the study. Figures 36 through 60 show that prior to dredging, Zones $3 \mathrm{~F}$ and $3 \mathrm{G}$ had a dense cover of vegetation. After dredging in the summer of 2000, open water habitat was created that is suitable for California red-legged frog breeding.

A similar number of egg masses were observed in the entire LLNL reach of Arroyo Las Positas in 2001 (37 egg masses), 2002 (32 egg masses), and 2003 (31 egg masses). Although the change in habitat resulting from dredging made Reach 3 unsuitable for California red-legged frog breeding, California red-legged frogs produced similar number of egg masses before and immediately after dredging.

In 2004, there was a sharp decline in the number of egg masses observed. Nine egg masses were observed in 2004, but more than 30 egg masses were observed in 2001, 2002, and 2003. It is unlikely that this change is due to habitat alteration resulting from dredging because no dredging occurred in the summer of 2003 and little changes in the habitat occurred between 2003 and 2004. More likely, explanations of this sharp decrease in number of egg masses in 2004 are high flows that resulted from a large rain event early in March of 2004 or increased pressure from exotic species including crayfish and bullfrogs. 


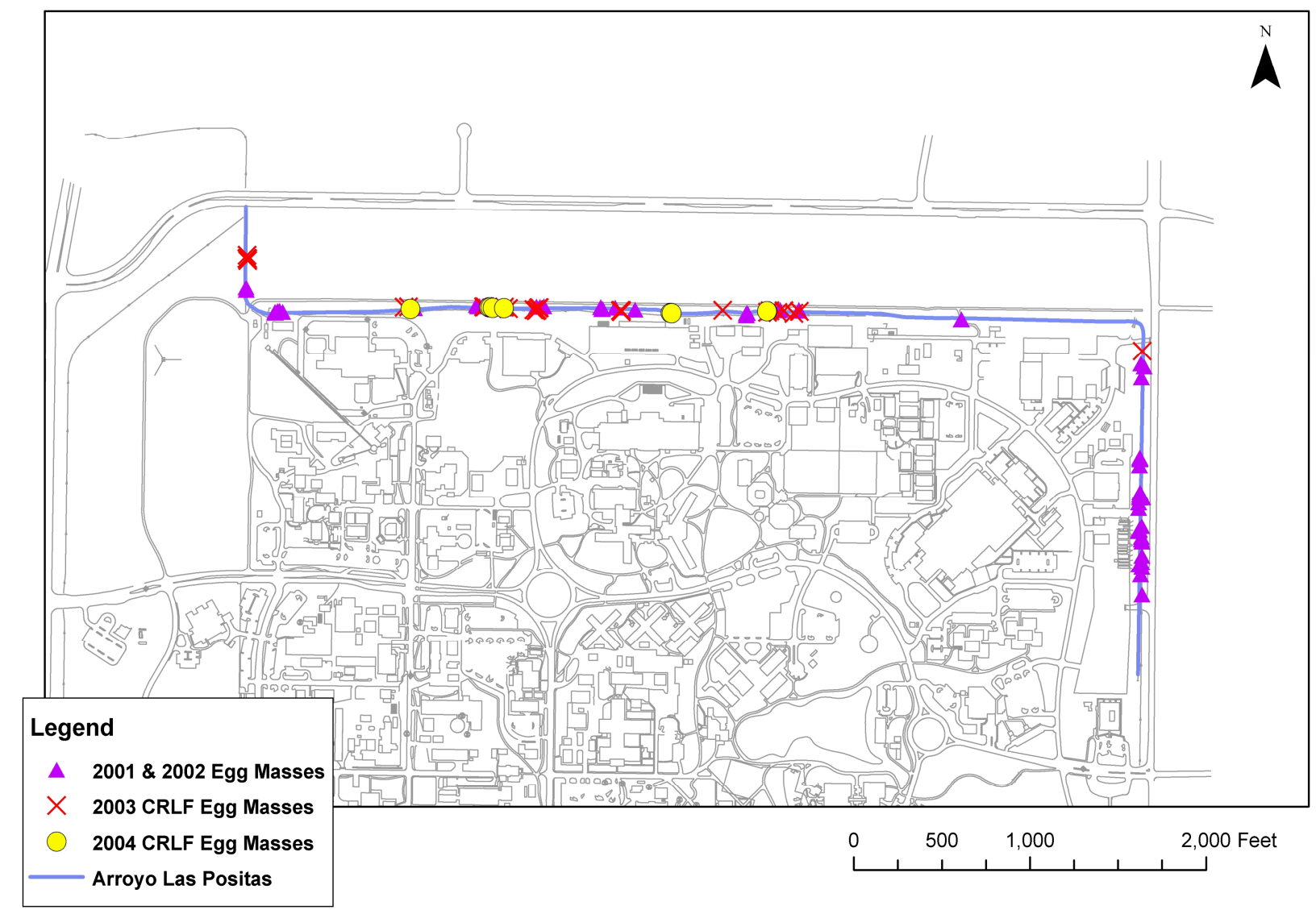

Figure 3. Location of California red-legged frog egg masses in winter and early spring from 2001 through 2004. 
Arroyo Las Positas Maintenance Impact Study

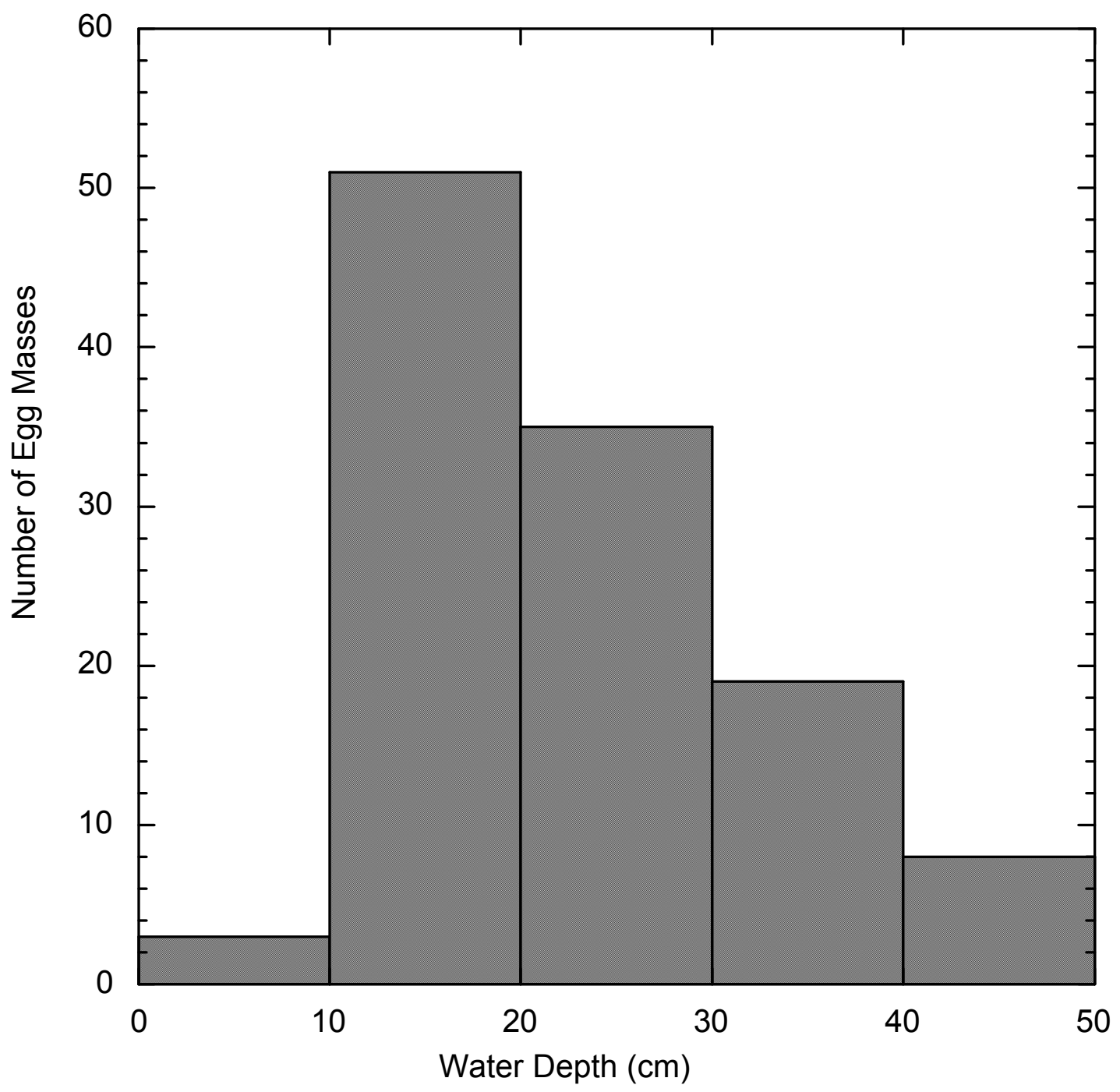

Figure 4. Histogram showing the depth of water at the location of egg mass attachment for egg masses observed from 2001 through 2004.

$\mathrm{N}=109$ (number of egg masses) 
Arroyo Las Positas Maintenance Impact Study

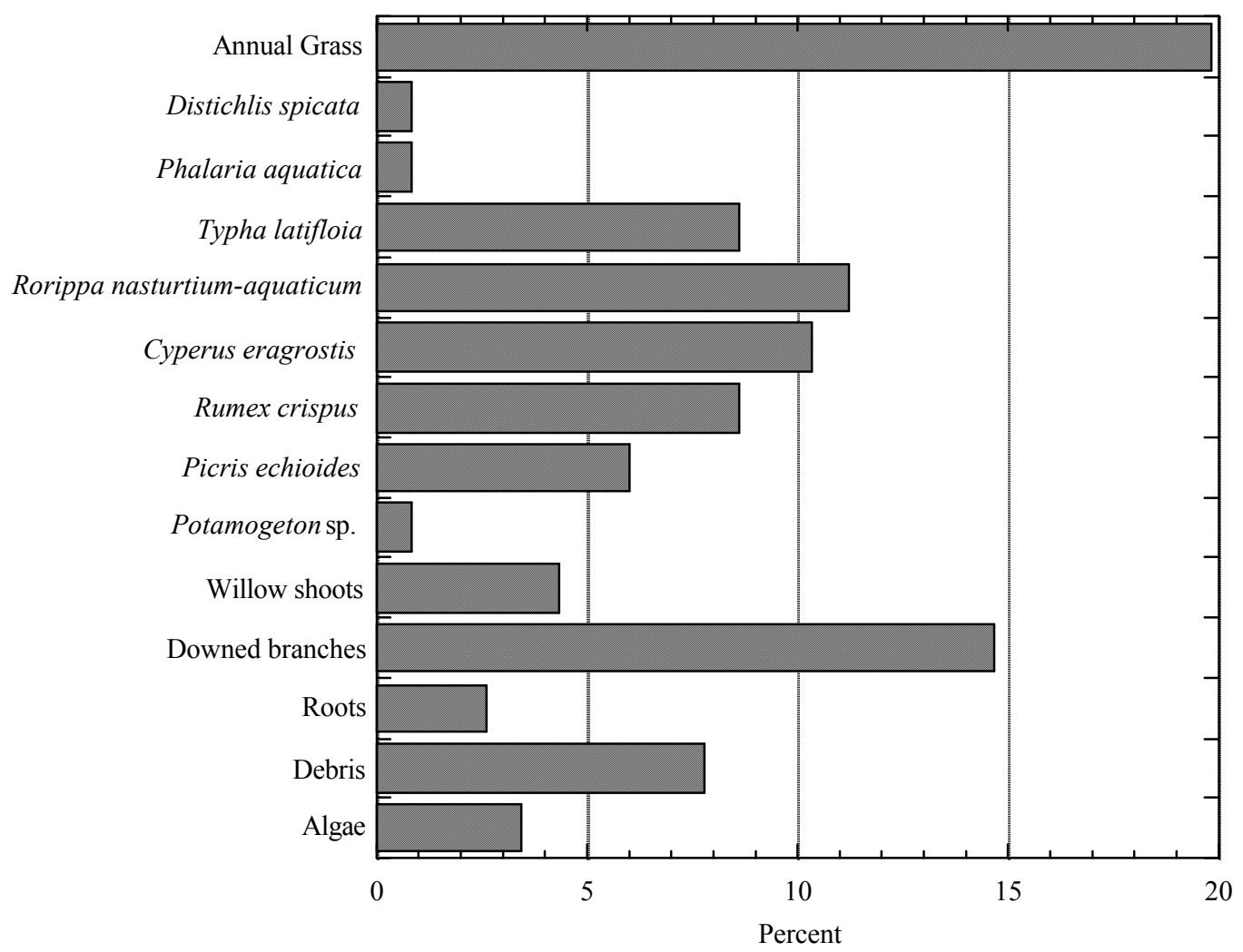

Figure 5. Attachment point for CRLF egg masses 2001-2004. $\mathrm{N}=109$ (number of egg masses). 


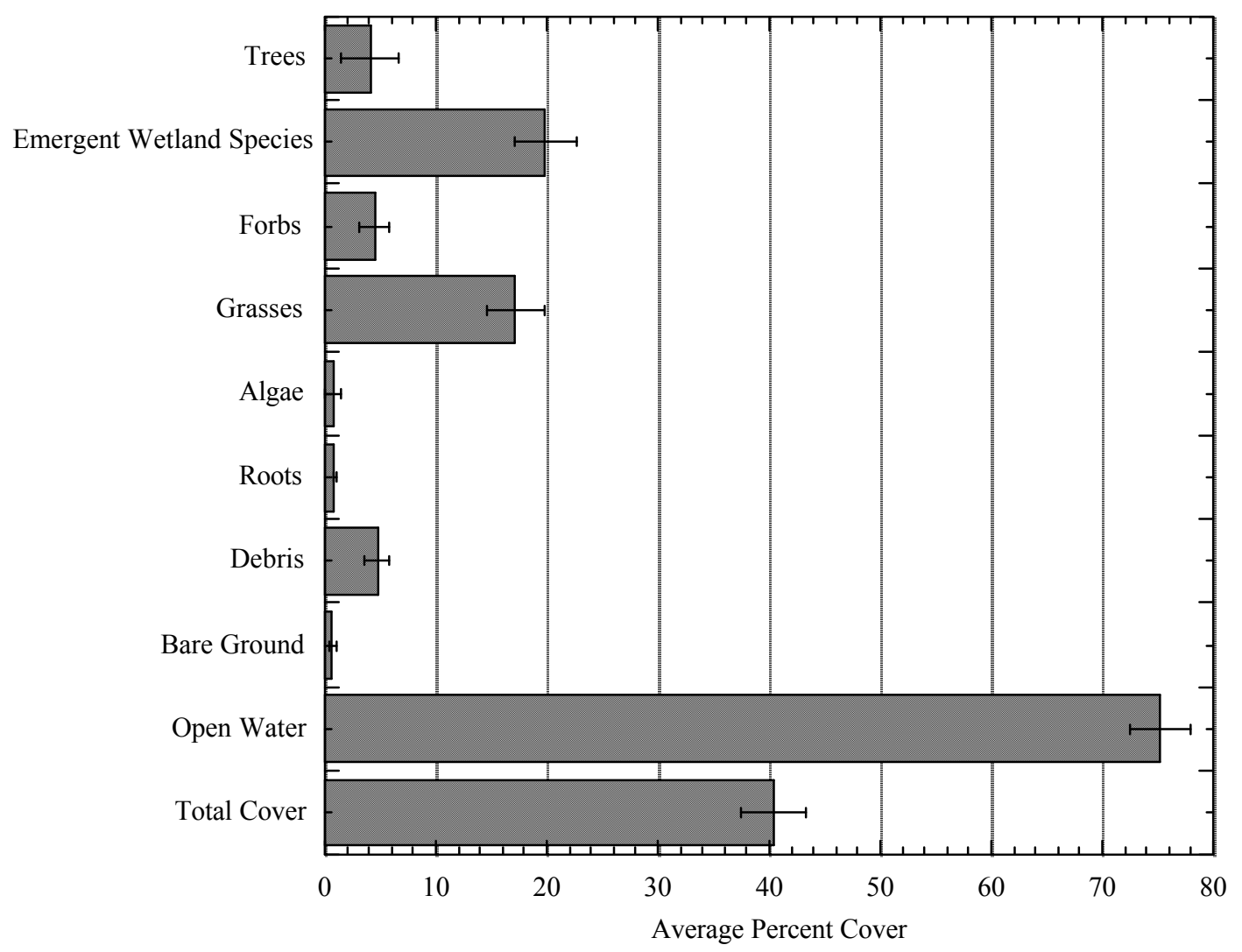

Figure 6. Average percent cover of vegetation types for 1- $\mathrm{m}^{2}$ quadrats centered on CRLF egg masses for egg masses observed in 2003 through 2004. $\mathrm{N}=46$ (number of quadrats). Values are averages $\pm 1 \mathrm{SE}$. 
Arroyo Las Positas Maintenance Impact Study

Table 1. Percent cover and constancy for $1 \mathrm{~m}^{2}$ quadrats center of $R$. a. draytonii egg masses in Arroyo Las Positas. Values are means $\pm \mathrm{SD}, \mathrm{N}=39$.

\begin{tabular}{lcc}
\hline \hline & Constancy $^{\mathrm{a}}$ & Percent Cove \\
\hline Total Cover & 89.7 & $34.0 \pm 19.7$ \\
Open Water & 97.4 & $64.0 \pm 17.9$ \\
Bare Ground & 7.7 & $0.4 \pm 1.8$ \\
Debris & 33.3 & $3.3 \pm 7.6$ \\
Roots & 2.6 & $0.1 \pm 0.8$ \\
Algae & 2.6 & $0.8 \pm 4.8$
\end{tabular}

Grasses

Avena fatua*

Distichlis spicata

2.6

$0.3 \pm 1.6$

Echinochloa crus-galli*

2.6

$0.3 \pm 1.6$

Lolium multiflorum*

20.5

$6.0 \pm 13.3$

Phalaris aquatica*

2.6

$0.1 \pm 0.4$

Unknown annual grass

7.7

$2.0 \pm 9.3$

$\underline{\text { Forbs }}$

Epilobium brachycarpum

46.2

$7.7 \pm 13.2$

Picris echioides*

2.6

$0.1 \pm 0.4$

Rumex crispus

15.4

$1.0 \pm 4.1$

Salsola tragus*

25.6

$2.7 \pm 7.5$

Vicia villosa*

2.6

$0.3 \pm 1.6$

2.6

$0.1 \pm 0.4$

Emergent Wetland Species

Cyperus eragrostis*

48.7

$5.6 \pm 10.7$

Polygonum persicaria*

2.6

$0.1 \pm 0.4$

Polypogon monspeliensis*

2.6

$0.5 \pm 3.2$

Rorippa nastutrium-aquaticum

33.3

$6.6 \pm 12.1$

Scripus robustus

2.6

$0.8 \pm 4.8$

Typha latifolia

20.5

$3.8 \pm 10.0$

$\underline{\text { Trees }}$

Salix exigua (mature-overhanging)

5.1

$3.3 \pm 14.9$

Salix exigua (shoots)

$7.7 \quad 0.8 \pm 2.7$

a Constancy $=($ The number of quadrats a species occurred in $) /($ the total number of quadrats) $* 100$

* Exotic Species 


\section{Macro-Invertebrate Monitoring}

Samples were taken from five sites over five years of study. Sites consisted of one control (1H) and four treatment $(3 \mathrm{E}-\mathrm{H})$. Sampling frequency varied by year. Three samples were taken in 2000 in order to document pre-project invertebrate community structure and densities at the control and treatment sites. Samples were taken twice in 2001, and once in years 2003 and 2005. For the purpose of this analysis, all treatment sites were compared to the control independently. The preliminary processing of the samples showed variation in densities and in invertebrate community structure both within and between sites over the 5 years of study that may not be clearly shown in the following indices (Appendix A).

\section{Zone 3E, Reach 2}

Invertebrate density increased immediately following dredging, but fell by $88 \%$ to near zero in 2001 . Densities increased to three times the pre-project levels in 2003, and fell in 2005 to near pre-project levels (Figure 7).

Seven invertebrate families were collected during both baseline surveys in the control site $1 \mathrm{H}$ in 2000 . Families collected in 3E ranged from 11 to 6 in June 2000 and July 2000 respectively. The number of families represented in $3 \mathrm{E}$ showed a steep drop relative to the control and to the baseline numbers following dredging activities in the summer of 2000 and remained low through October 2001. Families increased to near pre-project levels in 2003, but fell again in 2005. The most significant change occurred between the two pre-project samples when family numbers dropped by 55\% (Figure 8).

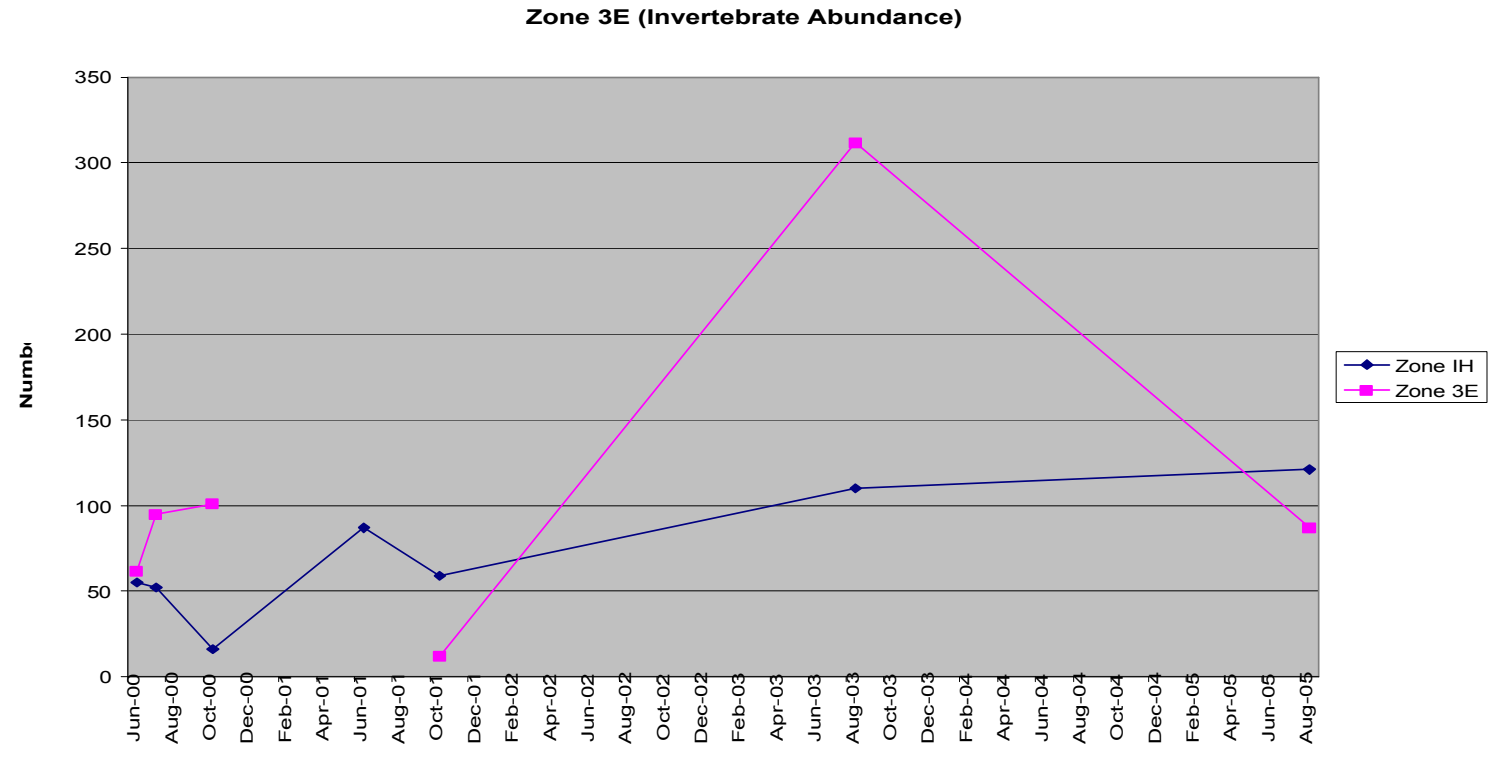

Figure 7. Macro-invertebrate abundance in Zone 3E between June 2000 and August 2005. 
Arroyo Las Positas Maintenance Impact Study

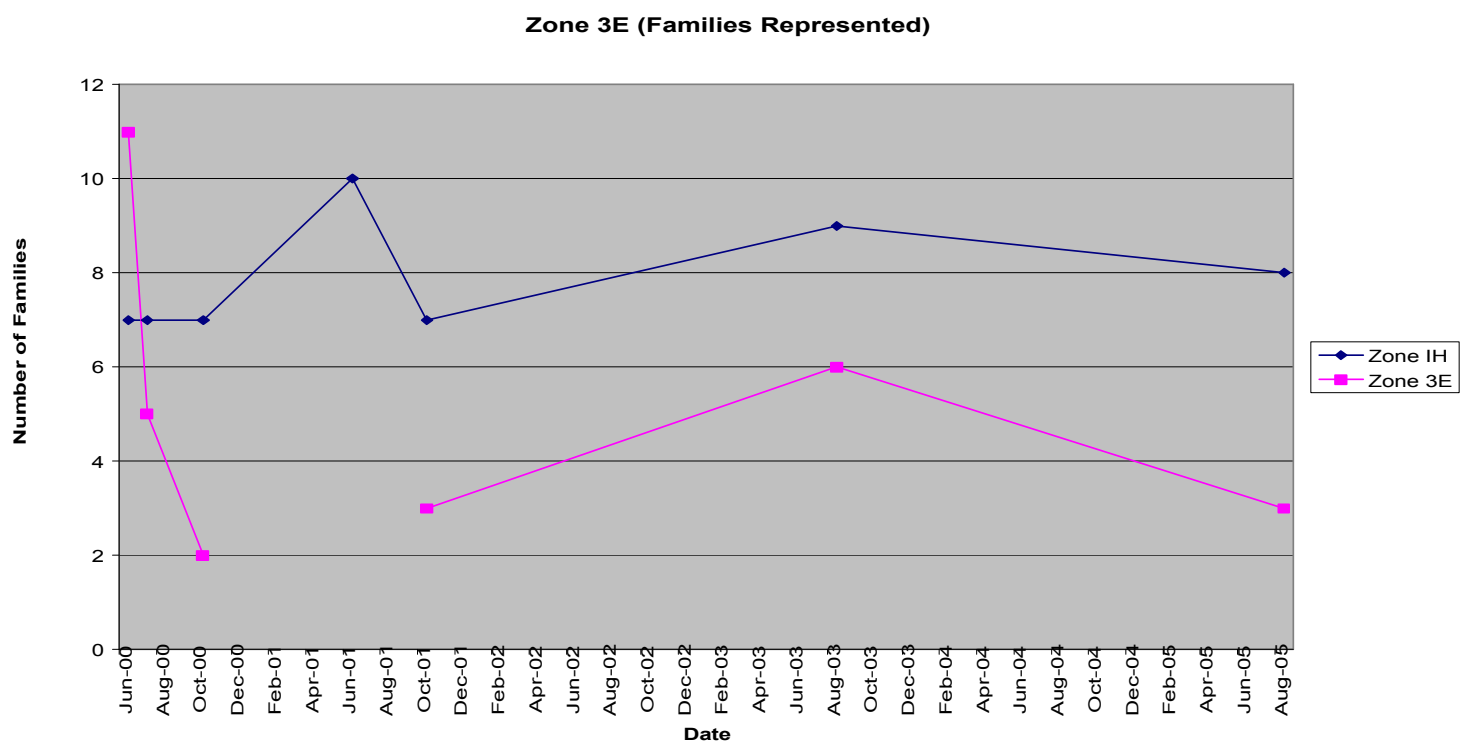

Figure 8. Number of macro-invertebrate families in Zone 3E between June 2000 and August 2005. 


\section{Zone 3F, Reach 2}

Invertebrate densities fell immediately following dredging through June 2001, after which they increased to about twice the pre-project levels through 2003 and 2005. Control densities showed a similar trend (Figure 9).

Seven invertebrate families were collected during both baseline surveys in the control site $1 \mathrm{H}$ in 2000 . Nine families were represented in site $3 \mathrm{~F}$ during the same time period. After dredging in the summer of 2000 , family numbers in site $3 \mathrm{~F}$ dropped by $66 \%$ to three through 2001 and increased to 8 in 2003 . The final survey yielded 6 families, 33\% below baseline numbers. Families represented in the control site were more abundant in all post dredging samples except in 2001 when they remained the same (Figure 10).

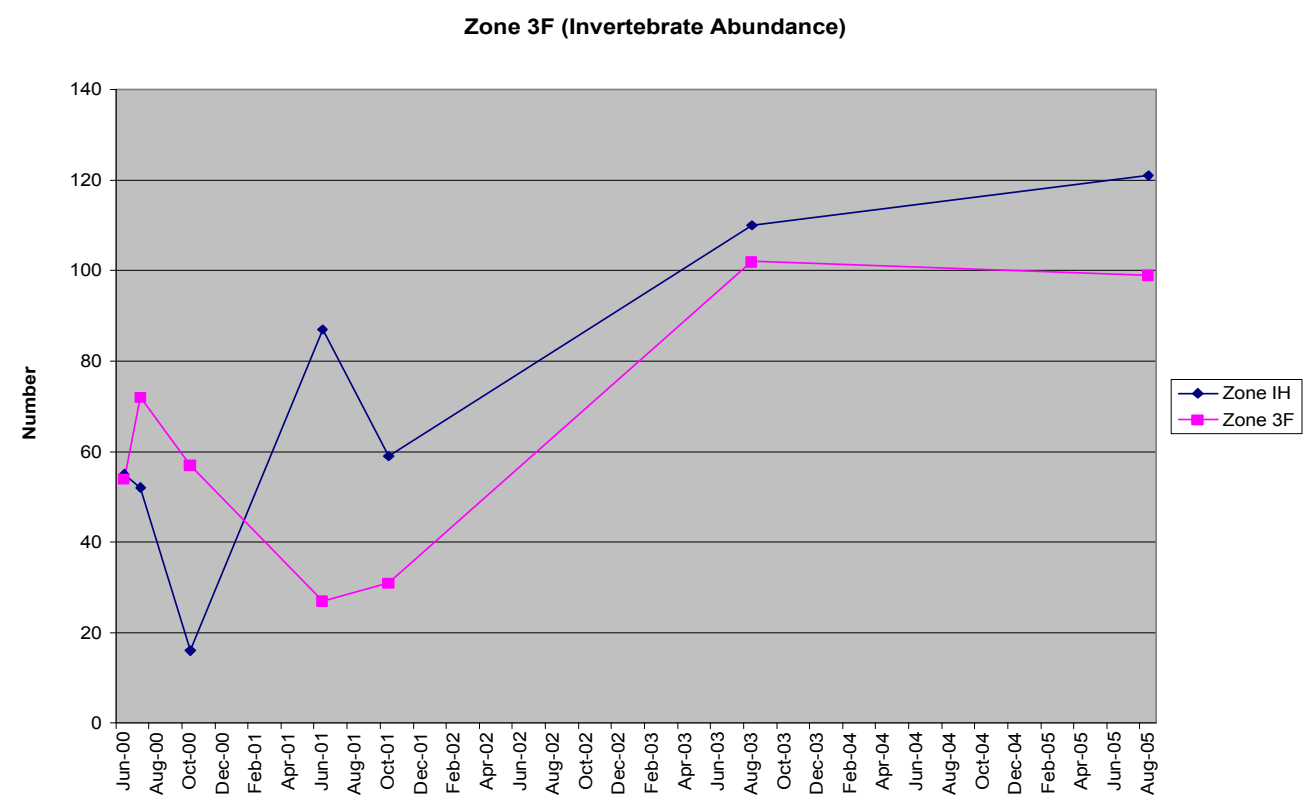

Figure 9. Macro-invertebrate abundance in Zone 3F between June 2000 and August 2005. 
Arroyo Las Positas Maintenance Impact Study

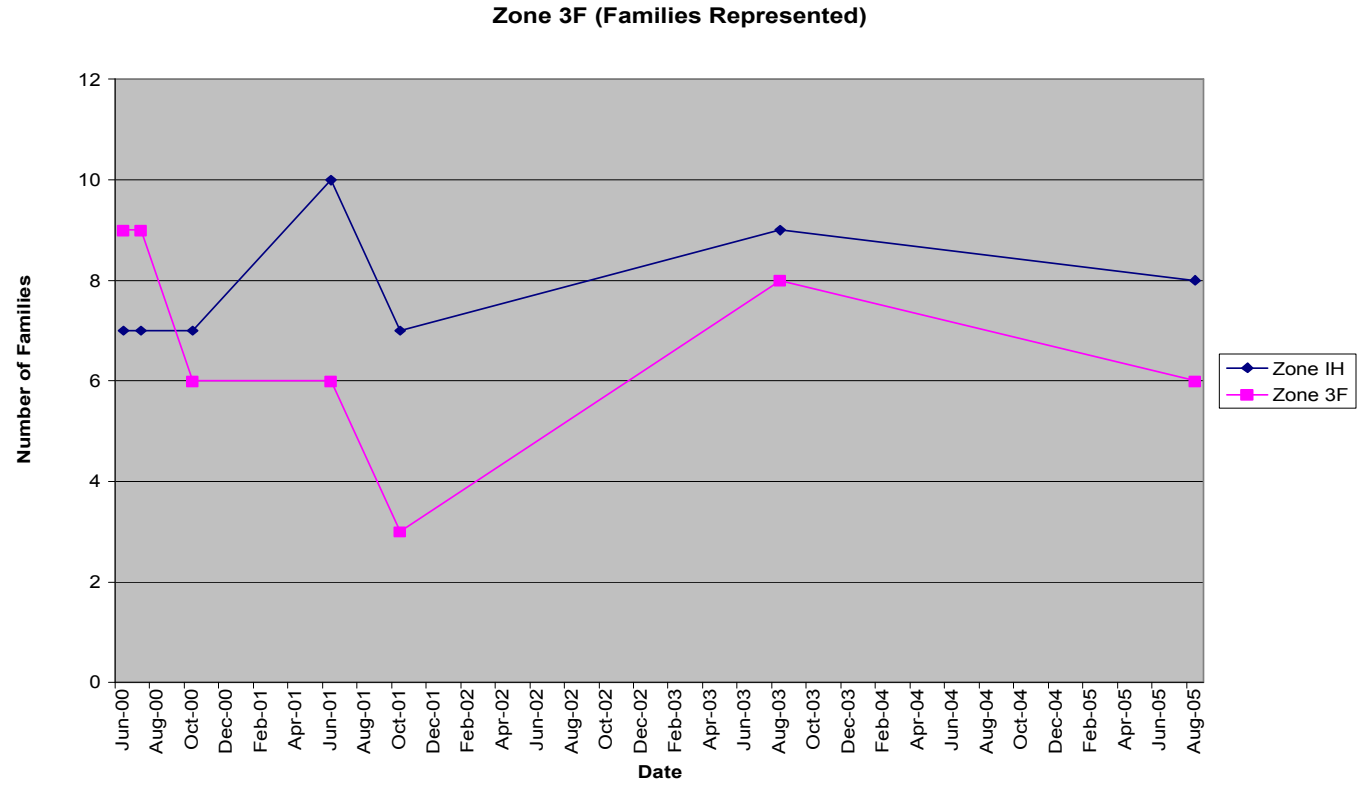

Figure 10. Number of macro-invertebrate families in Zone 3F between June 2000 and August 2005. 


\section{Zone 3G, Reach 2}

Invertebrate densities fell $46 \%$ in the October 2000 survey immediately following dredging. Densities rose steadily through 2005 to $30 \%$ above baseline levels. Control densities showed a similar trend (Figure 11).

Seven invertebrate families were collected during both baseline surveys in the control site $1 \mathrm{H}$ and in site $3 \mathrm{G}$. Family numbers in site $3 \mathrm{G}$ increased $57 \%$ in immediate post dredging samples. Family numbers remained high (9-10) through 2003, but dropped down to baseline levels in the 2005 sample. Families represented in the control site were more abundant in all post dredging samples except in 2001 when they remained the same (Figure 12).

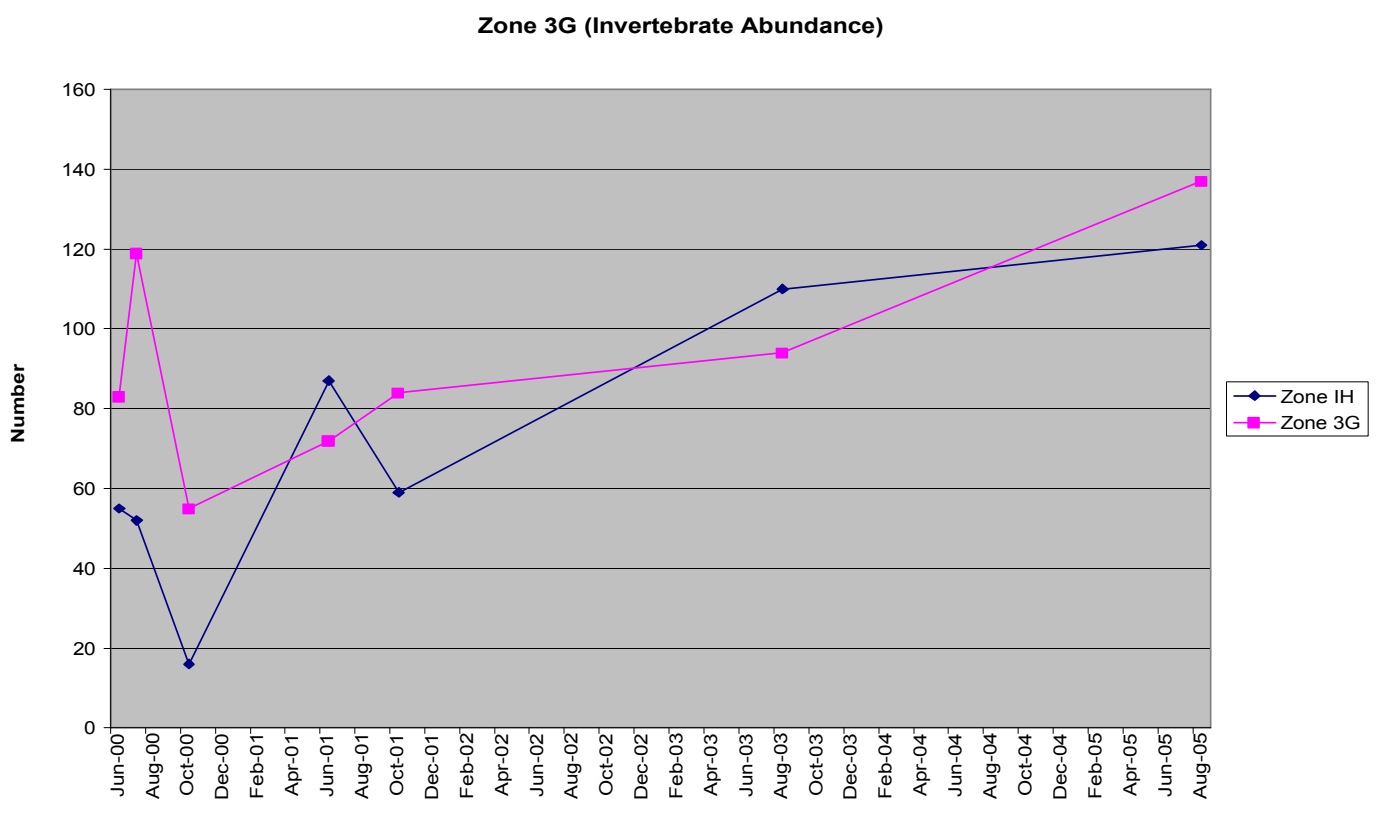

Figure 11. Macro-invertebrate abundance in Zone 3G between June 2000 and August 2005. 
Arroyo Las Positas Maintenance Impact Study

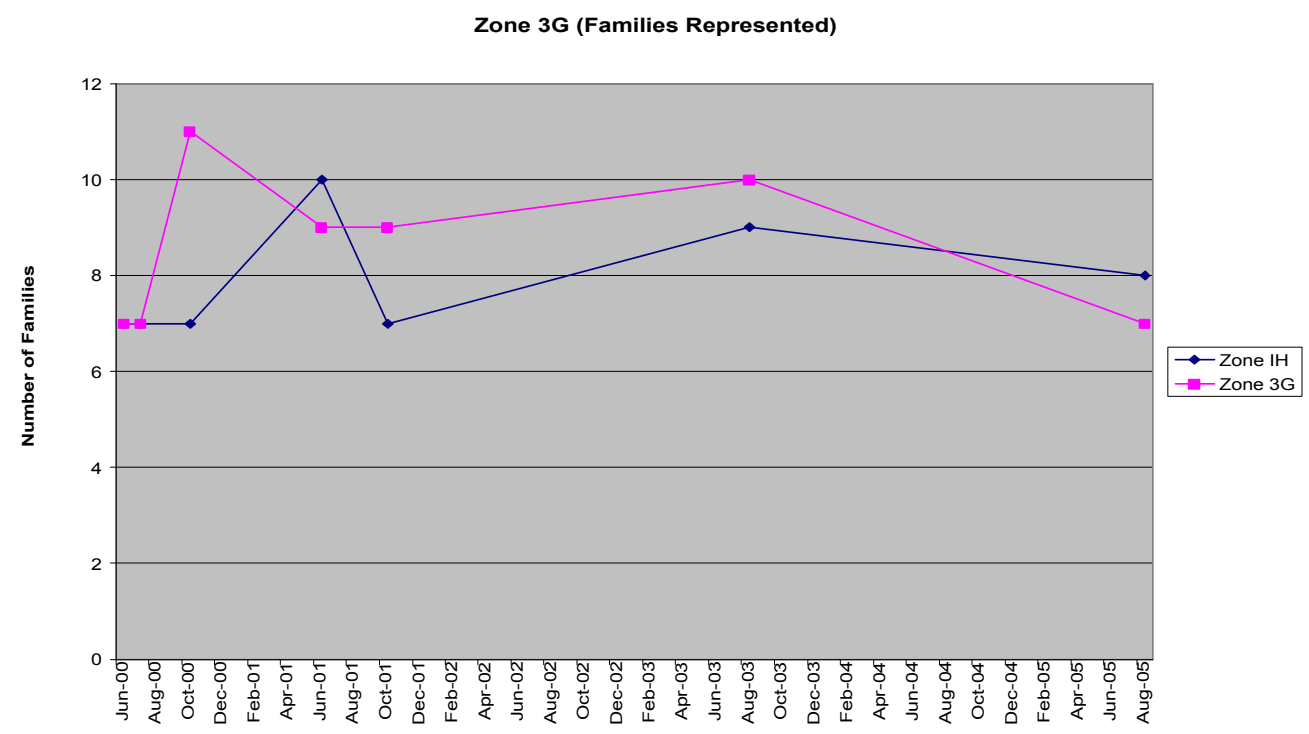

Figure 12. Number of macro-invertebrate families in Zone 3G between June 2000 and August 2005. 


\section{Vegetation Re-establishment}

The results of the vegetation re-establishment portion of this study are presented below. Descriptions of the results are given in the figure captions. Pre and post dredging photographs for Zone $3 \mathrm{C}$ are shown in Figures 13 through 22. Zone E photographs are shown in Figures 23 through 37. Zone F photographs are shown in Figures 38 through 47, and Zone G photographs are shown in Figures 48 through 50.

The composition of the vegetation communities in Zones 3C, 3E, 3F and 3G are shown in Tables 2 through 5 . 


\section{0: Zone 3C (including 1D, 2A, 1C), Reach 1}

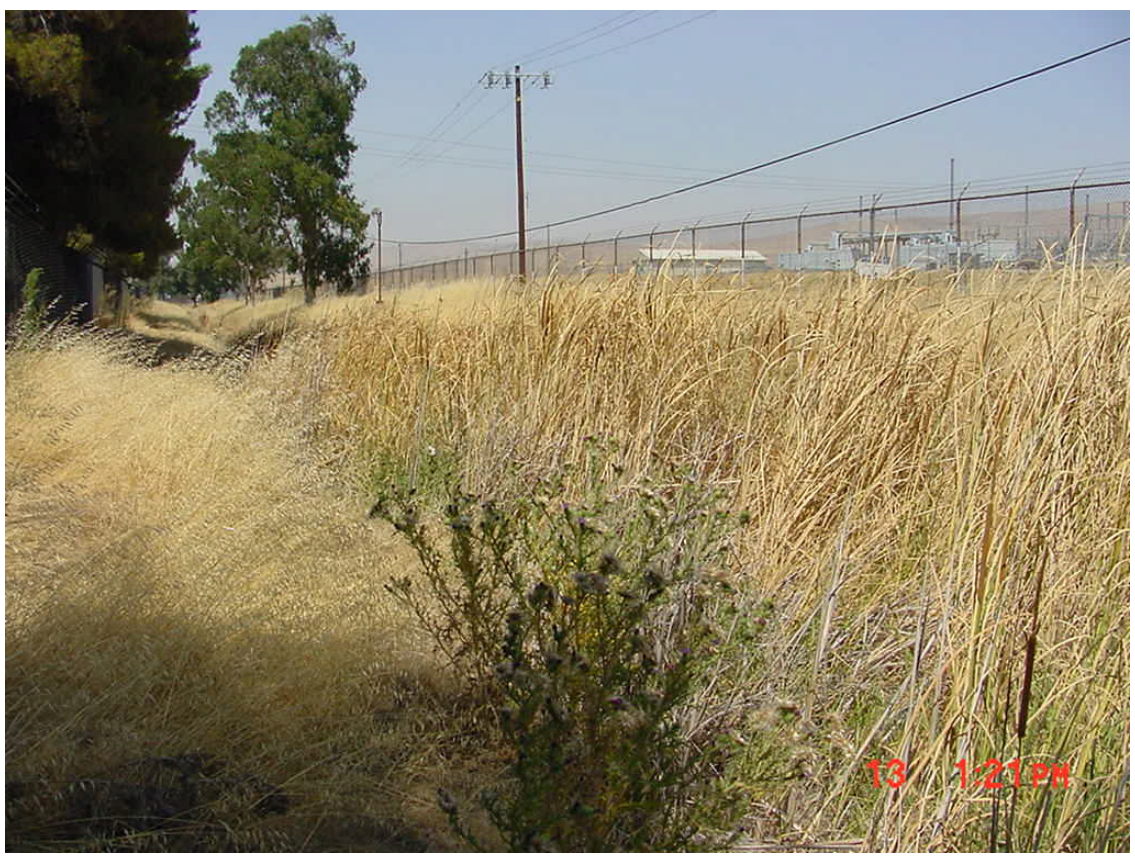

Figure 13. Zone 3C was uniformly cattail dominated in 2000. The above photograph was actually taken from Zone 3B, adjacent to 3C. As shown in this Figure and Figure 14, cattails dominated Reach 1 from the ALP infall to the northeast corner and the start of Reach 2.

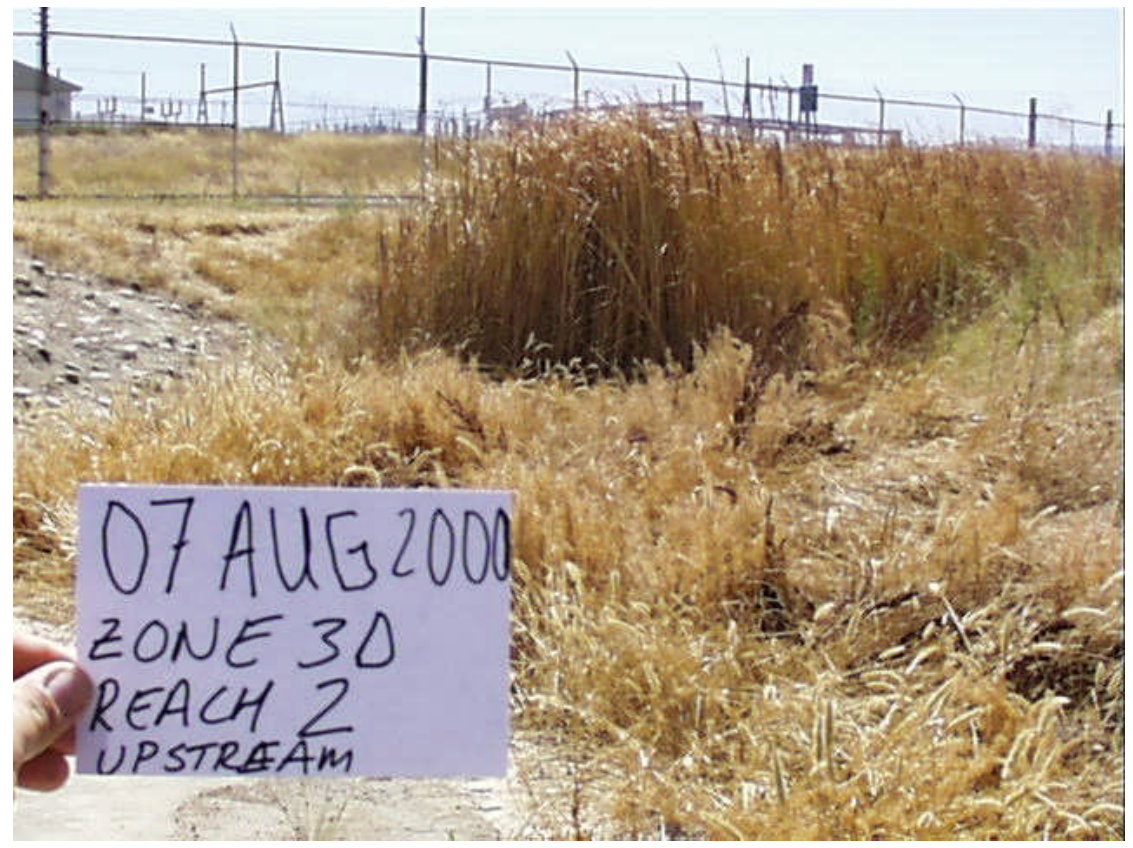

Figure 14. Zone 3D is uniformly cattails as described in Figure 13, from the ALP infall to the transition to Reach 2. Although this figure is not of Zone $3 \mathrm{C}$, it shows the uniformity of cattail through the Reach 1. 
Arroyo Las Positas Maintenance Impact Study

Table 2. Plants found within the wetted portion of the Zone 3E channel prior to dredging in 2000. Dominant species are in bold.

\begin{tabular}{|l|l|}
\hline \multicolumn{1}{|c|}{ COMMON NAME } & \multicolumn{1}{c|}{ SCIENTIFIC NAME } \\
\hline Broad-leaved cattail & Typha latifolia \\
\hline Narrow-leaved cattail & Typha angustifolia \\
\hline Clustered dock & Rumex conglomeratus \\
\hline Curly dock & Rumex crispus \\
\hline Field binweed & Convulvulus arvensis \\
\hline Buckhorn plantain & Plantgo lanceolata \\
\hline Saltgrass & Distichilis spicata \\
\hline Yellow star-thistle & Centaurea solstitalis \\
\hline
\end{tabular}


2001: Zone 3C (including 1D, 2A, 1C), Reach 1

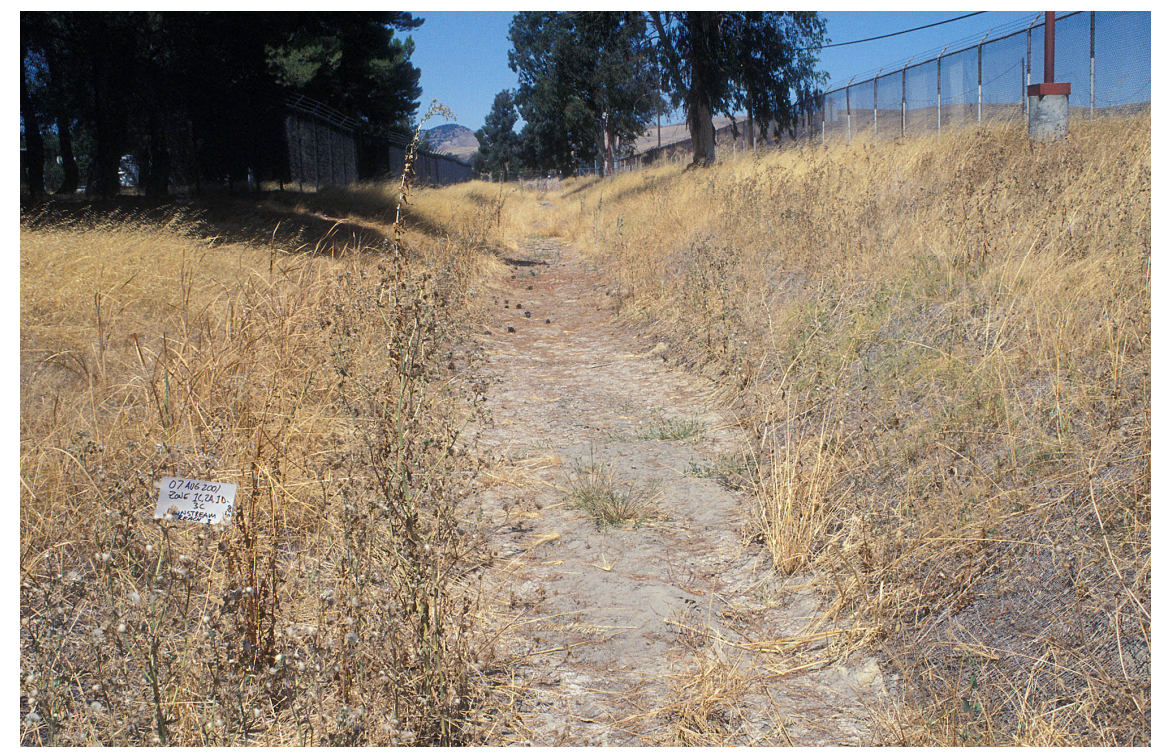

Figure 15. In 2001, Zone 3C (downstream view) contained no water by summer so vegetation re-growth was limited to exotic annual grasses.

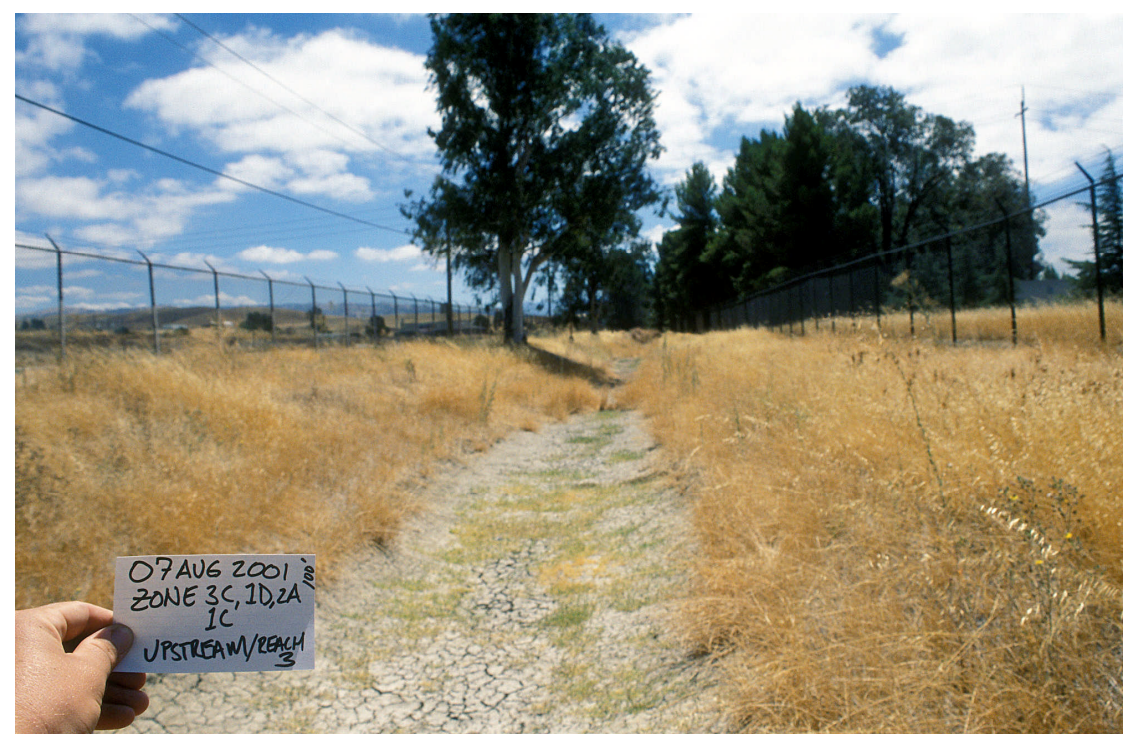

Figure 16. Re-growth in the lower portion of Zone 3C was limited to exotic annual grasses. 
2002: Zone 3C (including 1D, 2A, 1C), Reach 1

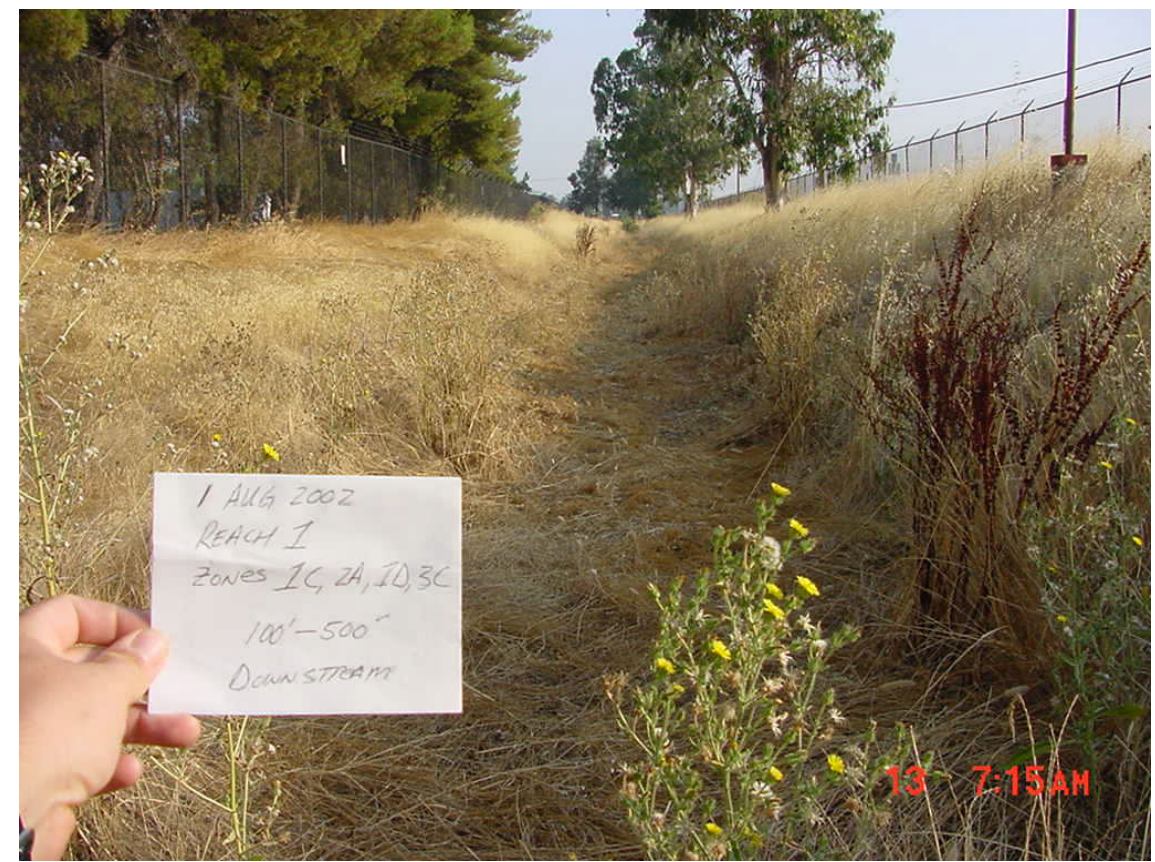

Figure 17. In 2002, Zone 3C showed uniform coverage by annual grasses and limited growth of clustered dock and spiny sowthistle.

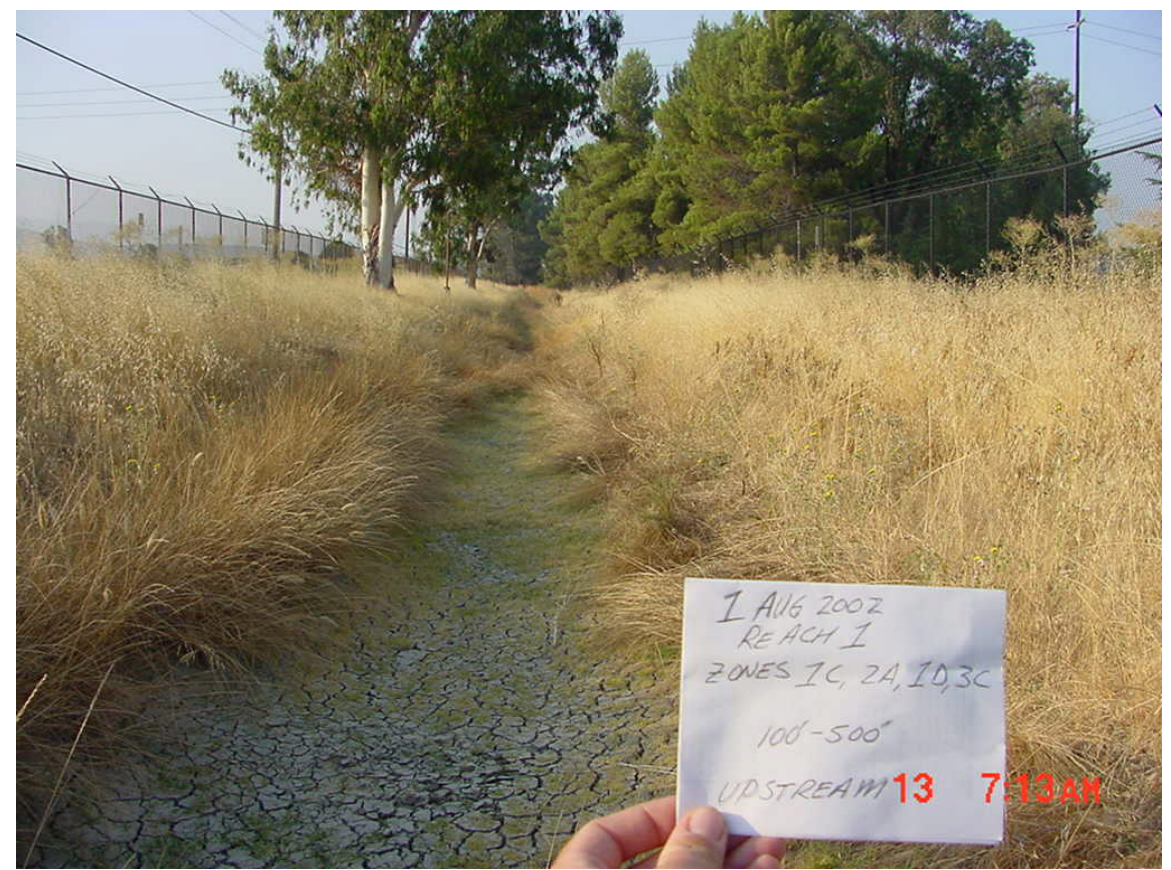

Figure 18. Re-growth in the lower portion of Zone 3C remained unchanged from 2001. 


\section{3: Zone 3C (including 1D, 2A, 1C), Reach 1}

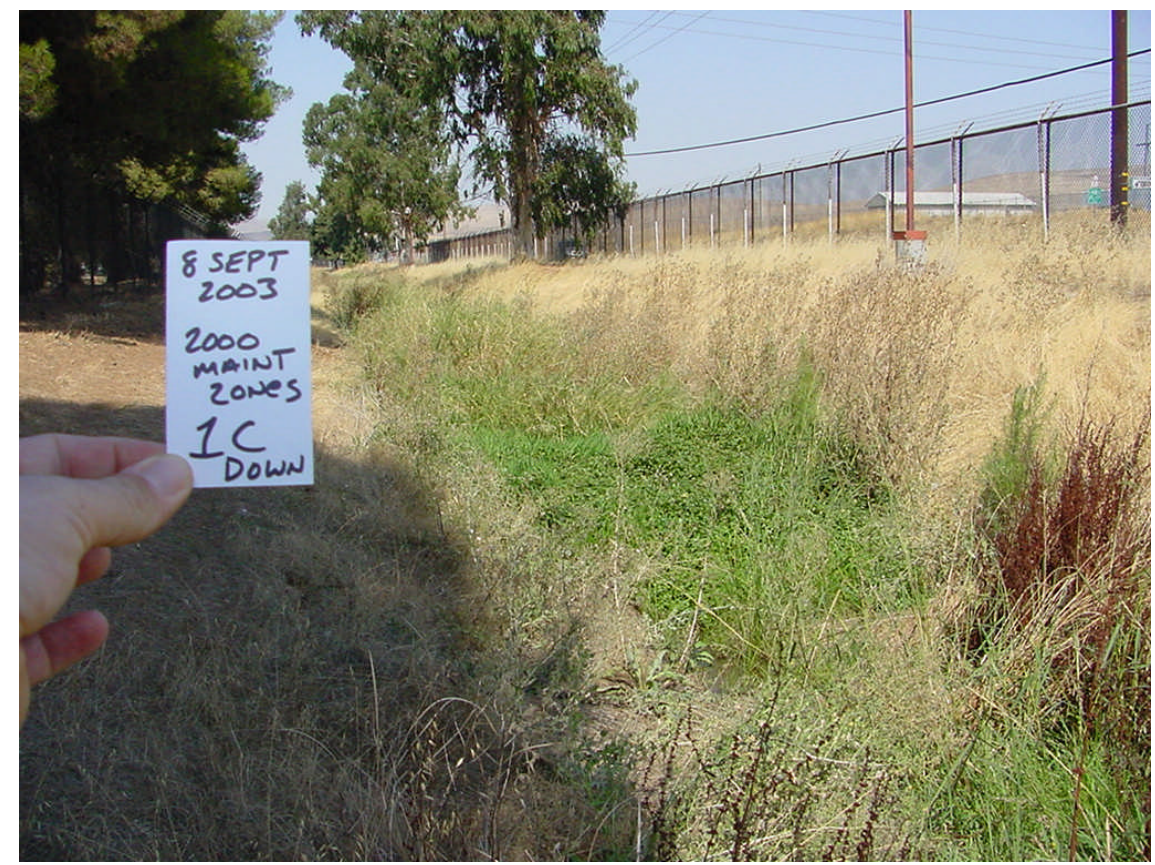

Figure 19. In 2003, Zone 3C showed substantial growth due to unseasonal hydration associated with offsite water management. Species diversity was similar to previous years.

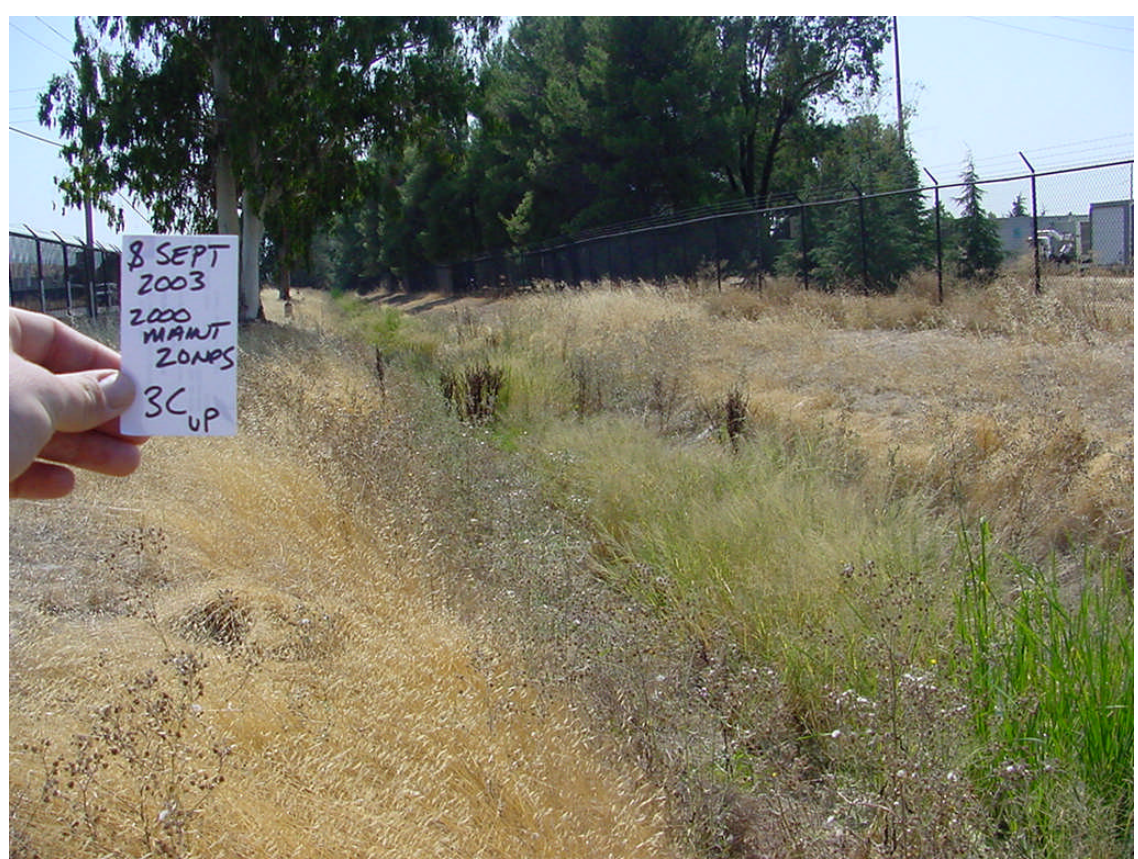

Figure 20. Similar to the upper portion of Zone 3C, substantial growth occurred in 2003 due to hydration from offsite water management, however, most of the growth was Italian ryegrass (Lolium multiflorum). 
Arroyo Las Positas Maintenance Impact Study

2004: Zone 3C (including 1D, 2A, 1C), Reach 1

No Photos Taken in 2004 for these zones 
2005: Zone 3C (including 1D, 2A, 1C), Reach 1

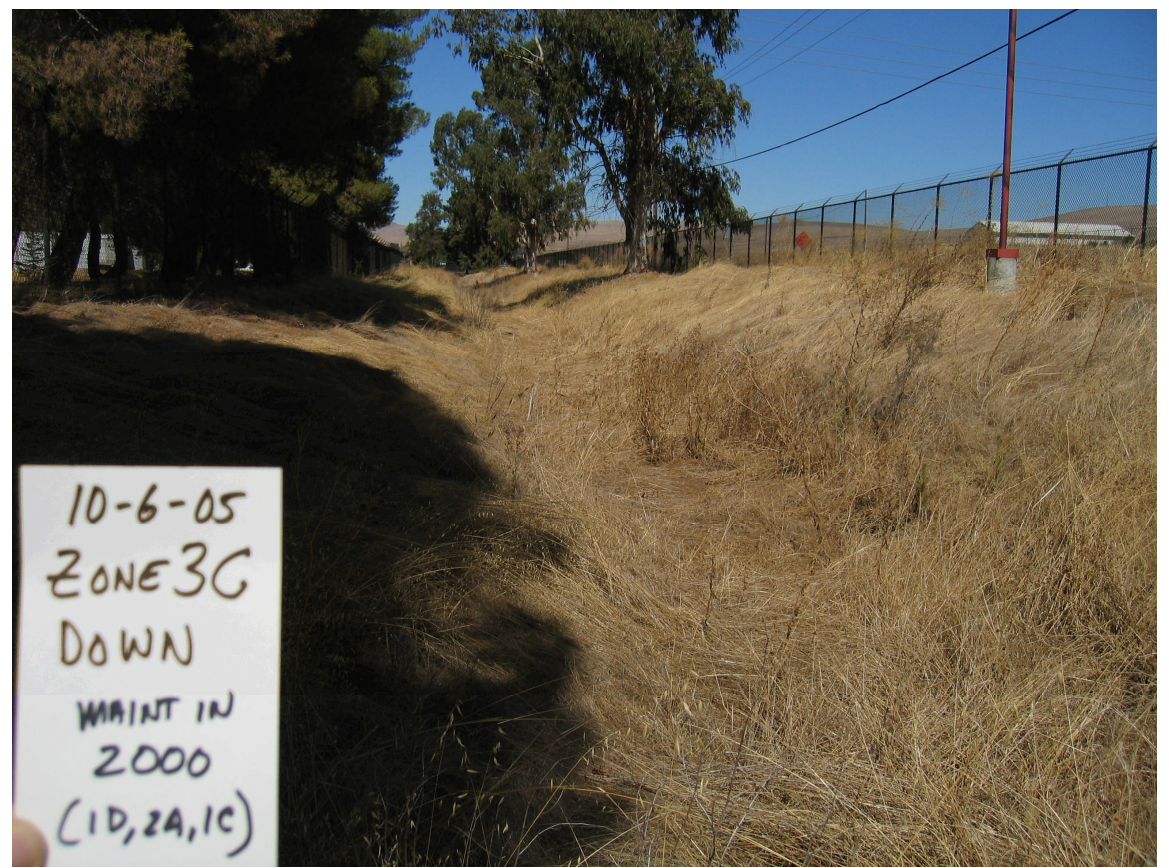

Figure 21. By 2005, the water that was entering the ALP in Reach 1 (2003) was gone and dry conditions prevailed. Vegetation was mostly wild oats, Italian ryegrass, and spiny sowthistle.

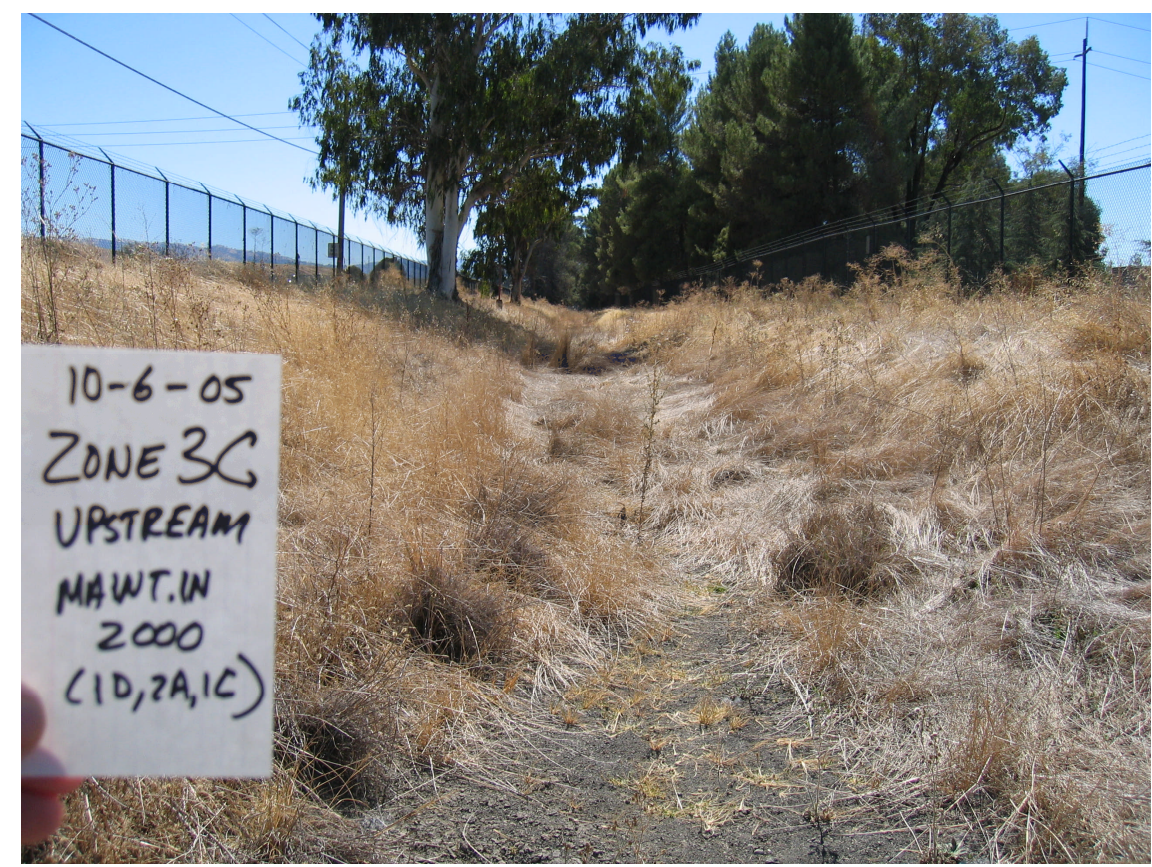

Figure 22. Similarly to the upper portions of $3 \mathrm{C}$, the lower sections were dry and lacked wetland vegetation. 


\section{0: Zone 3E, Reach 2}

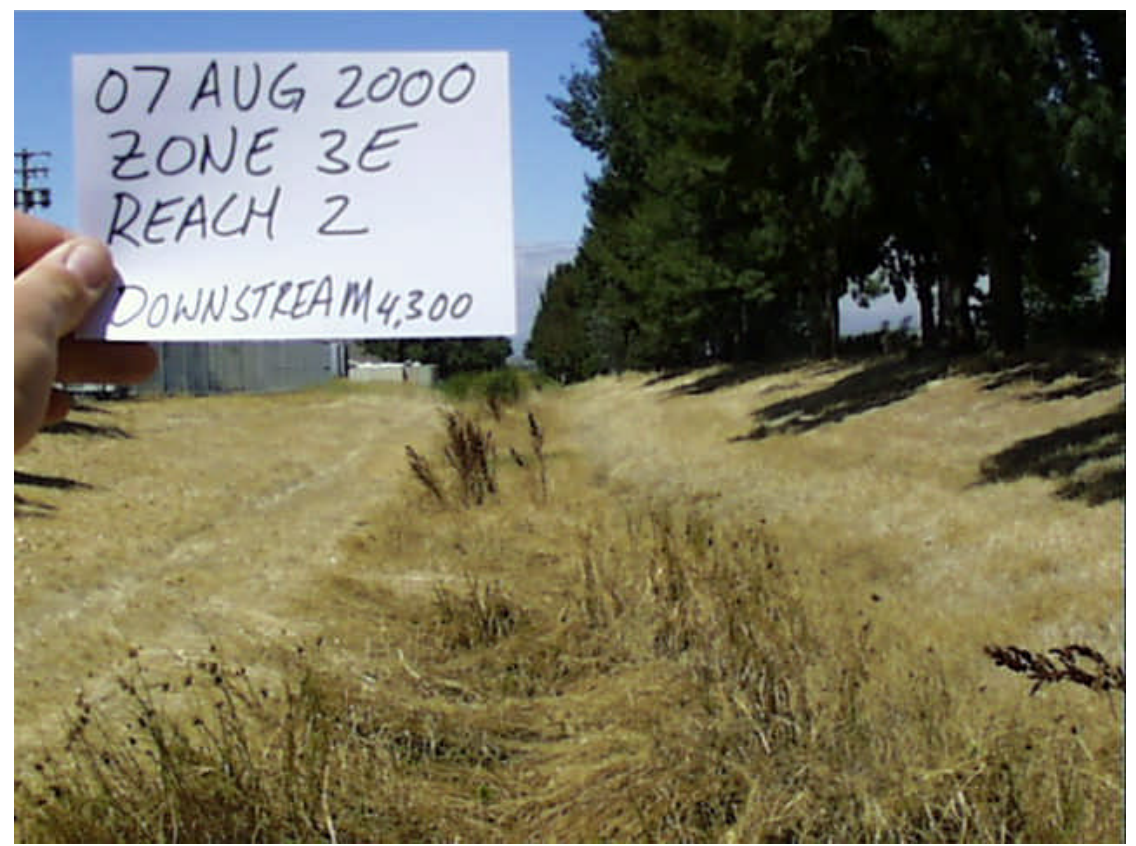

Figure 23 . The upper $60 \%$ of Zone $3 \mathrm{E}$ is hydrated naturally through rainfall and not CERCLA effluent, therefore, the upper portion of $3 \mathrm{E}$ (downstream view) is dry during most summers. Species like rabbitfoot polypogon, clustered dock, and alkali bulrush were most common in this portion of the zone.

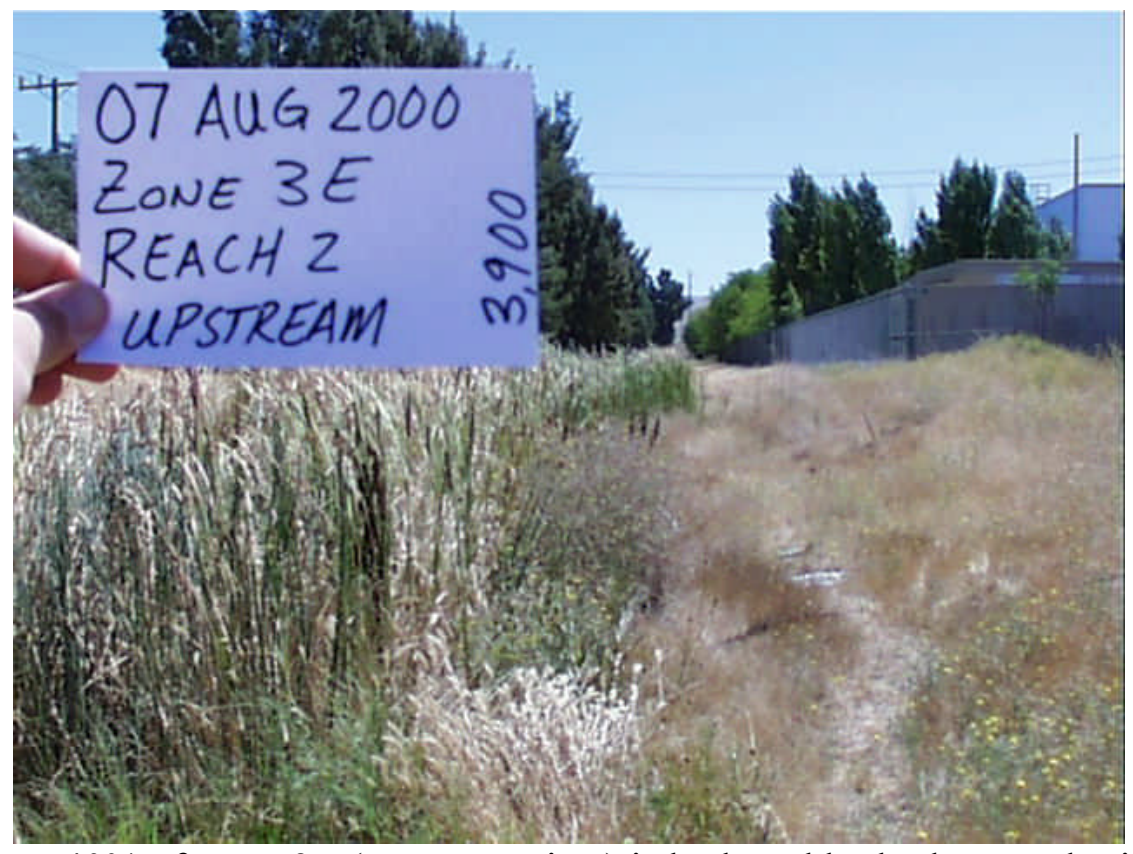

Figure 24. The lower $40 \%$ of Zone $3 \mathrm{E}$ (upstream view) is hydrated by both natural rainfall and runoff from site landscaping. The resulting cattail growth (shown in the photograph) is a function of the artificial flow (note the perpendicular growth of cattails at the bottom right of the identification card). 
Table 3. Plants found within the wetted portion of the Zone 3E channel prior to dredging in 2000. Dominant species are in bold.

\begin{tabular}{|l|l|}
\hline \multicolumn{1}{|c|}{ COMMON NAME } & \multicolumn{1}{c|}{ SCIENTIFIC NAME } \\
\hline Ripgut brome & Bromus diandrus \\
\hline Saltgrass & Distichlis spicata \\
\hline Alkali bullrush & Scirpus bobustus \\
\hline Bull thistle & Cirsium vulgare \\
\hline Beefwood & Casuarina sp. \\
\hline Rabbitfoot polypogon & Polypogon monspeliensis \\
\hline Spiny sowthistle & Sonchus asper \\
\hline Broad-leaved cattail & Typha latifolia \\
\hline Narrow leaved-cattail & Typha angustifolia \\
\hline Clustered dock & Rumex conglomeratus \\
\hline Bulrush & Scirpus sp. \\
\hline
\end{tabular}

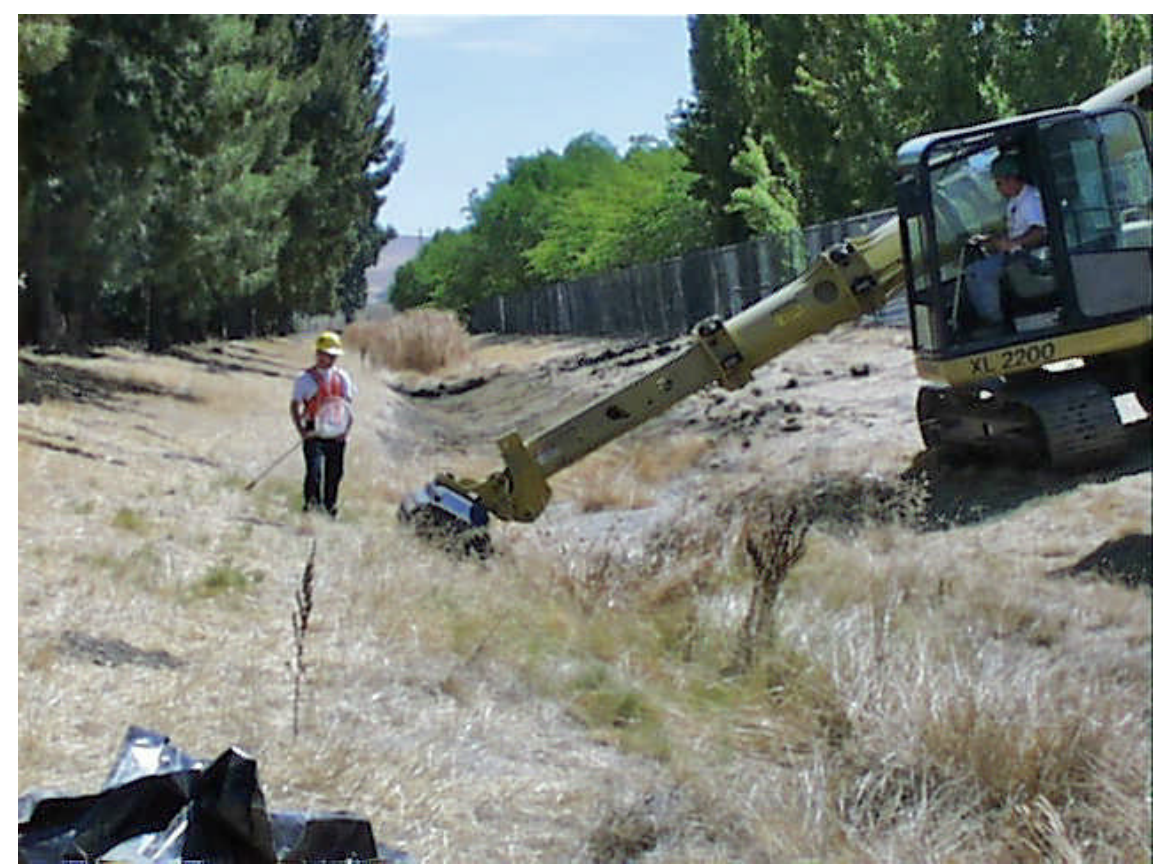

Figure 25. A biologist closely monitored all dredging activities to reduce the potential of California red-legged frog mortality. 
2001: Zone 3E, Reach 2

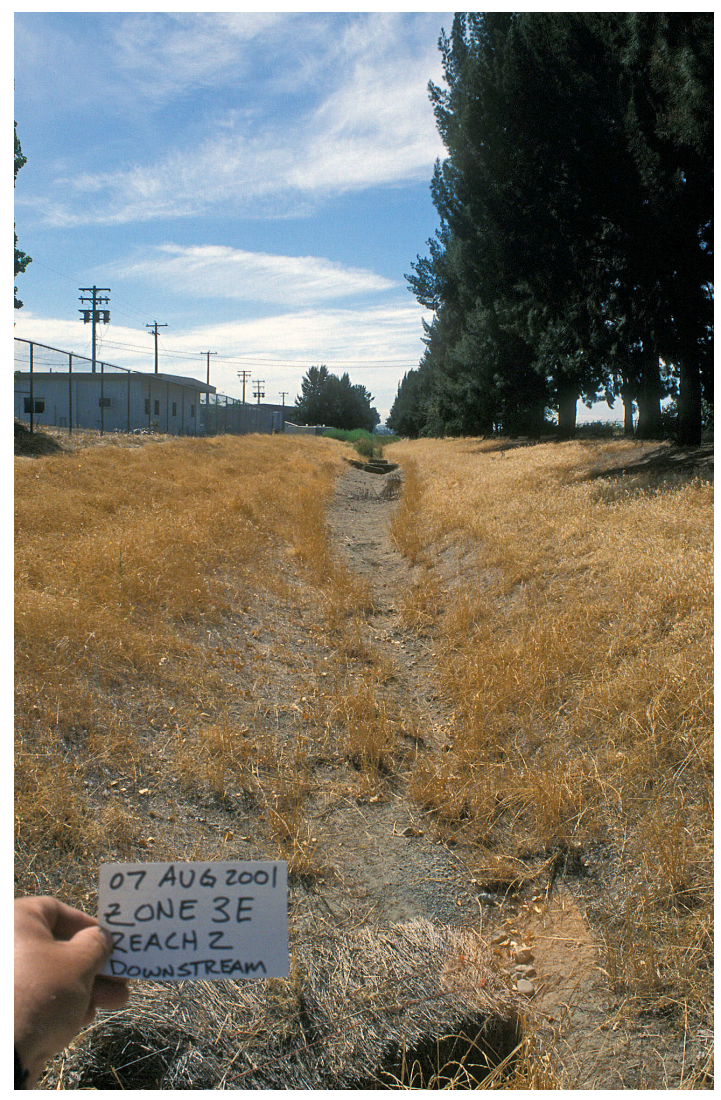

Figure 26. The upper portion of Zone 3E showed no natural wetland recovery in 2001 .

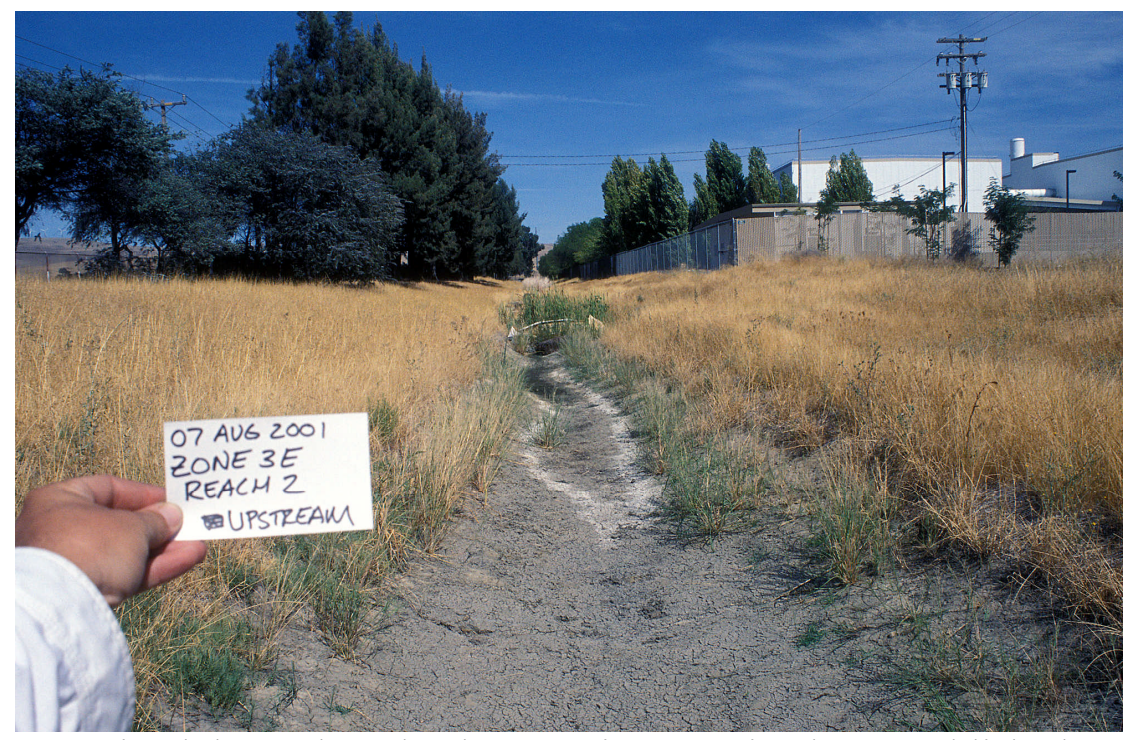

Figure 27. Zone 3E remained dry and wetland vegetation remained un-established except where cattails developed near the center of the zone where site landscaping runoff enters the zone from a storm drain. 


\section{2: Zone 3E, Reach 2}

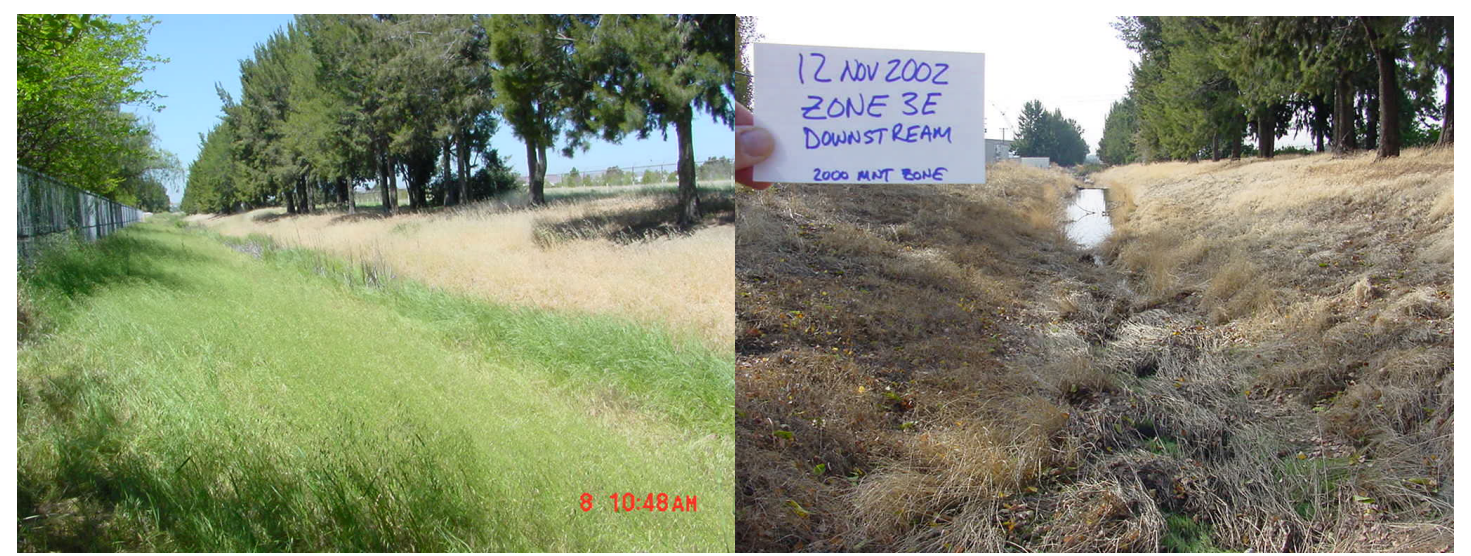

Figure 28. Zone 3E with summer annual grass growth (left) consisting mostly of wild oats (Avena fatua) and then again in fall (right) with pool formation up the storm drain outfall.

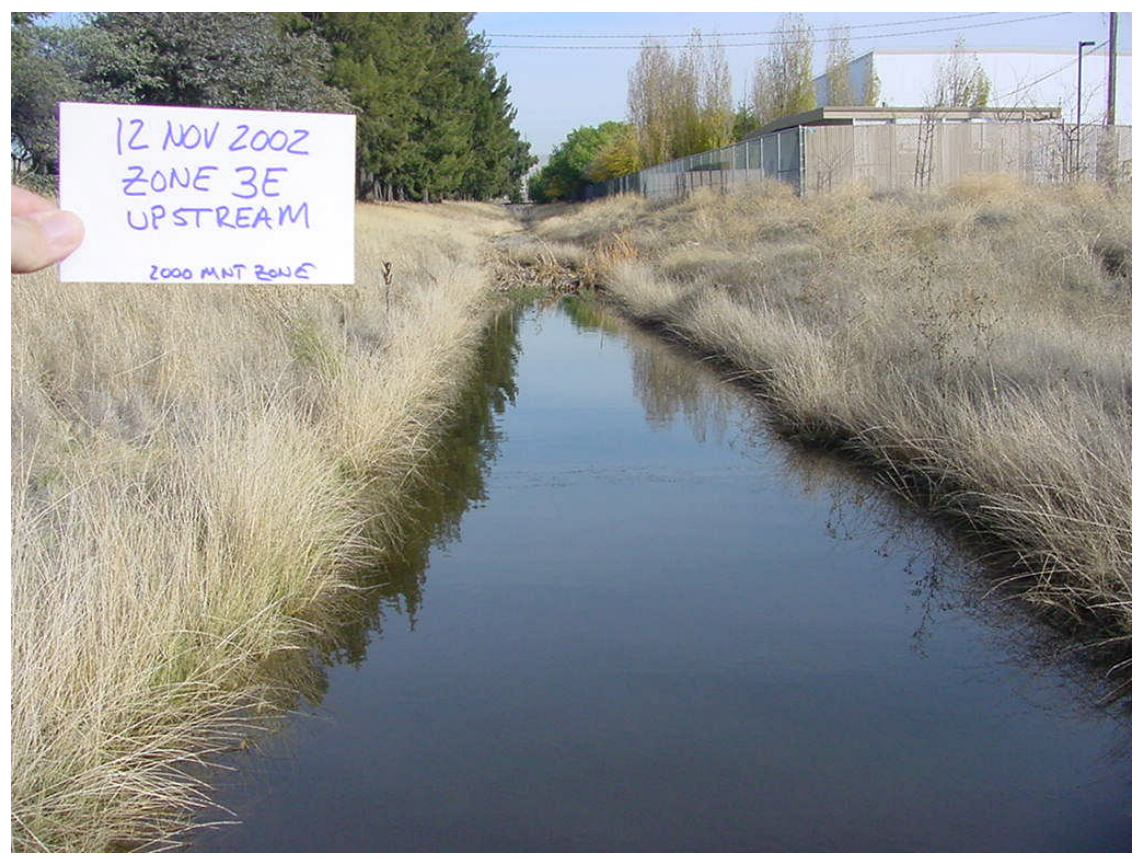

Figure 29. Zone 3E hydrated with storm drain effluent. 


\section{3: Zone 3E, Reach 2}

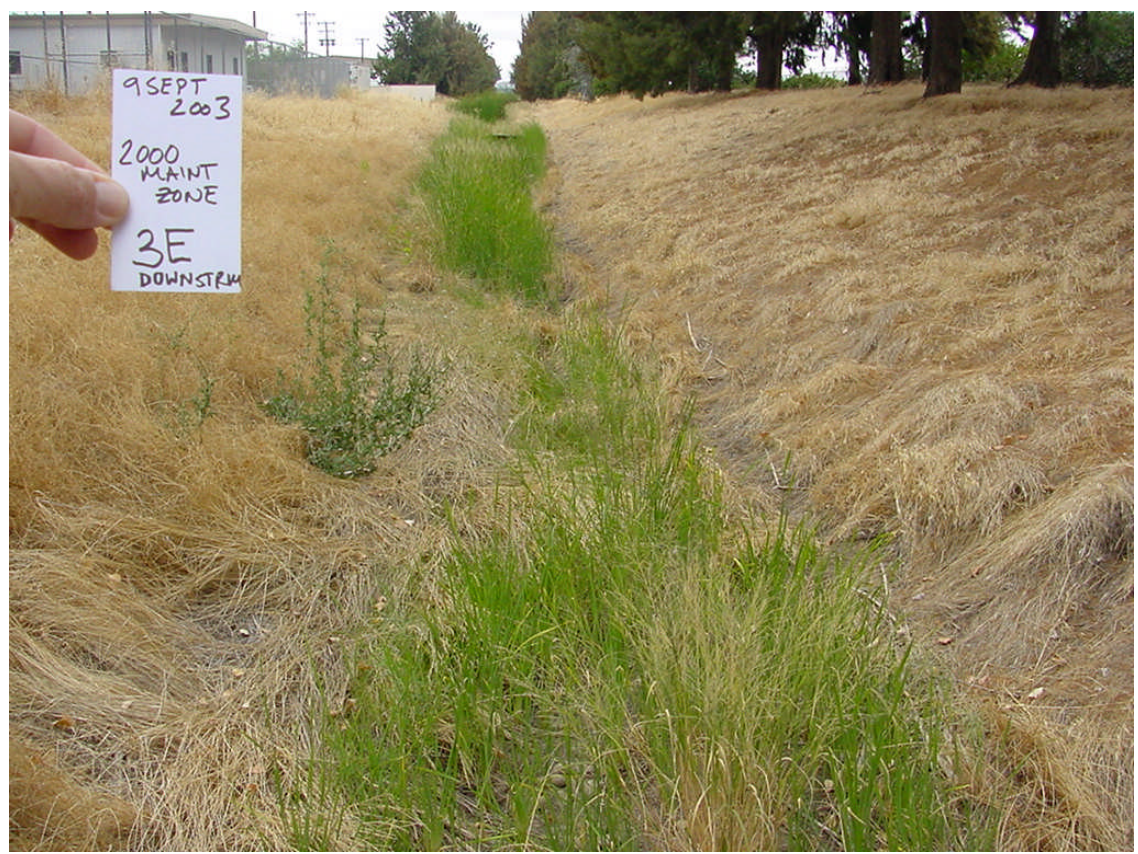

Figure 30 . Zone $3 \mathrm{E}$ with annual grass growth consisting mostly of wild oats.

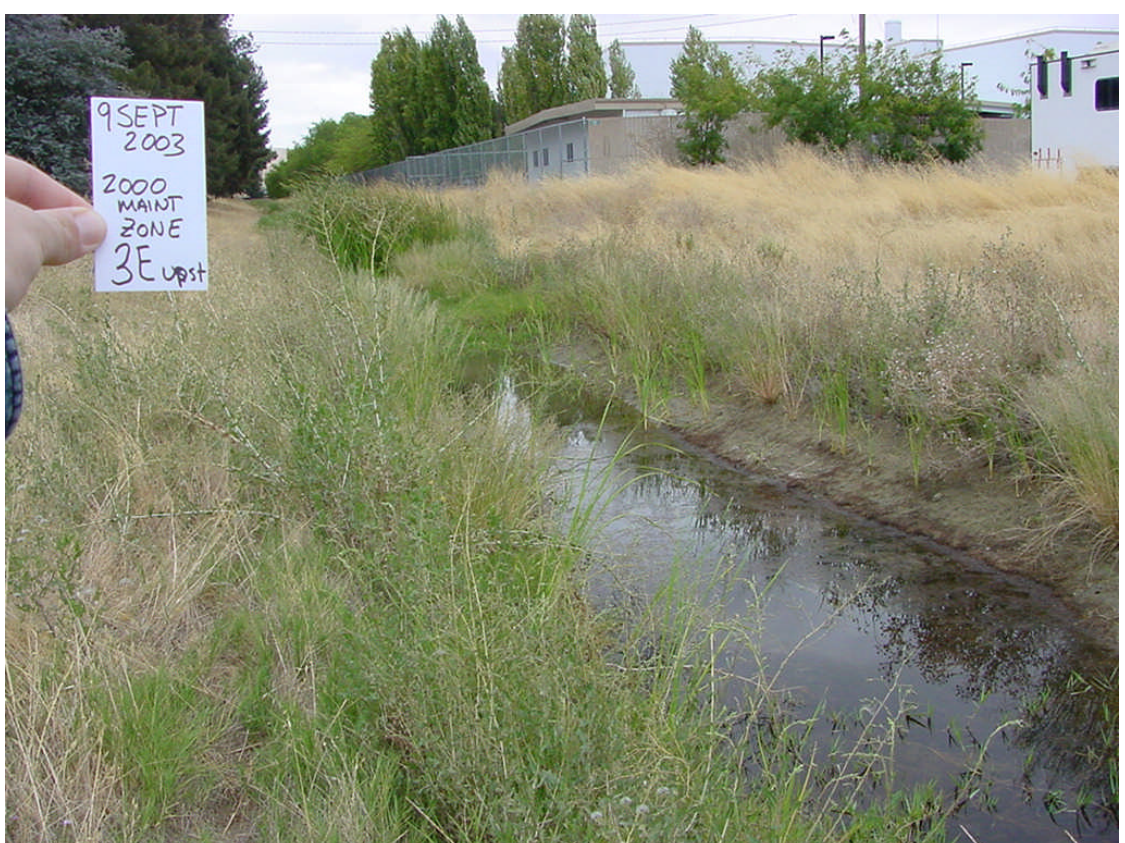

Figure 31. Zone 3E continued to be hydrated, but with little formation of hydrophytes except at the outfall of the storm drain near the middle of the zone. 


\section{4: Zone 3E, Reach 2}

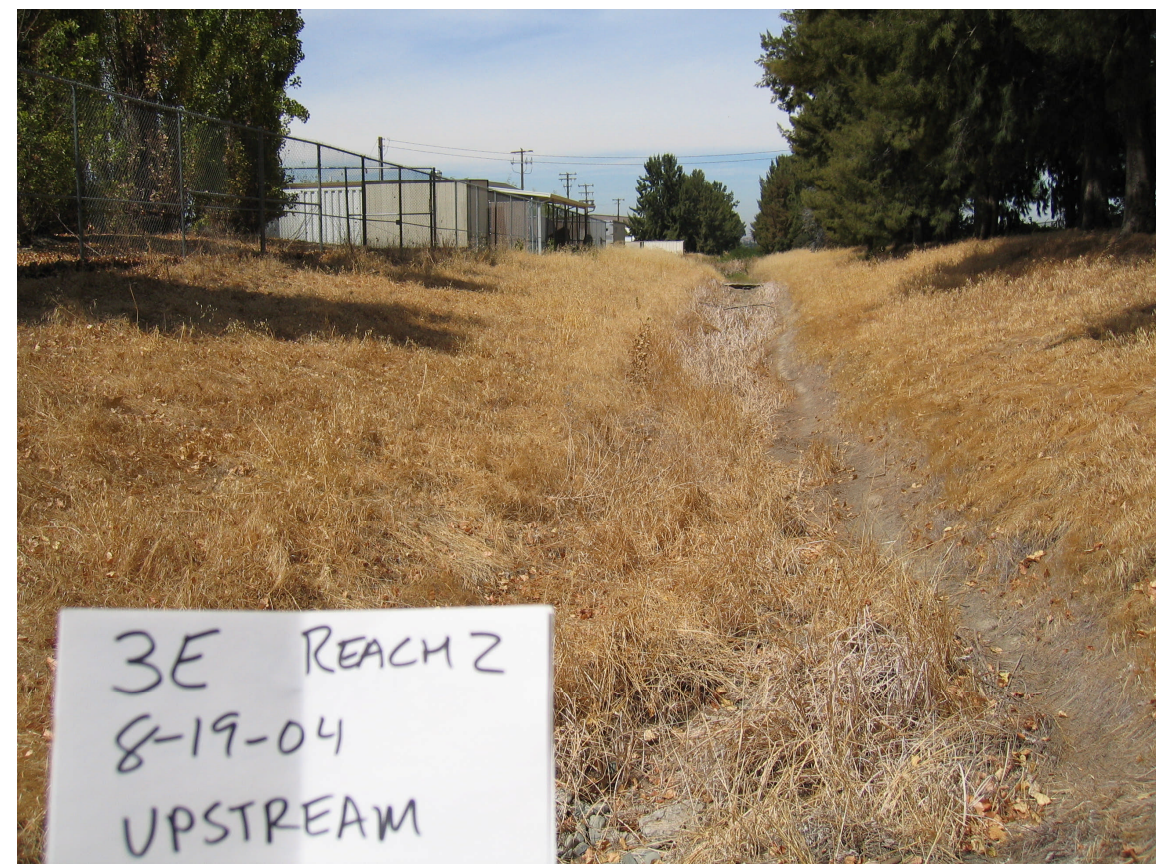

Figure 32. Zone 3E with annual grass growth consisting mostly of wild oats. Note the identification card is mislabeled as "upstream view," but is actually the downstream view.

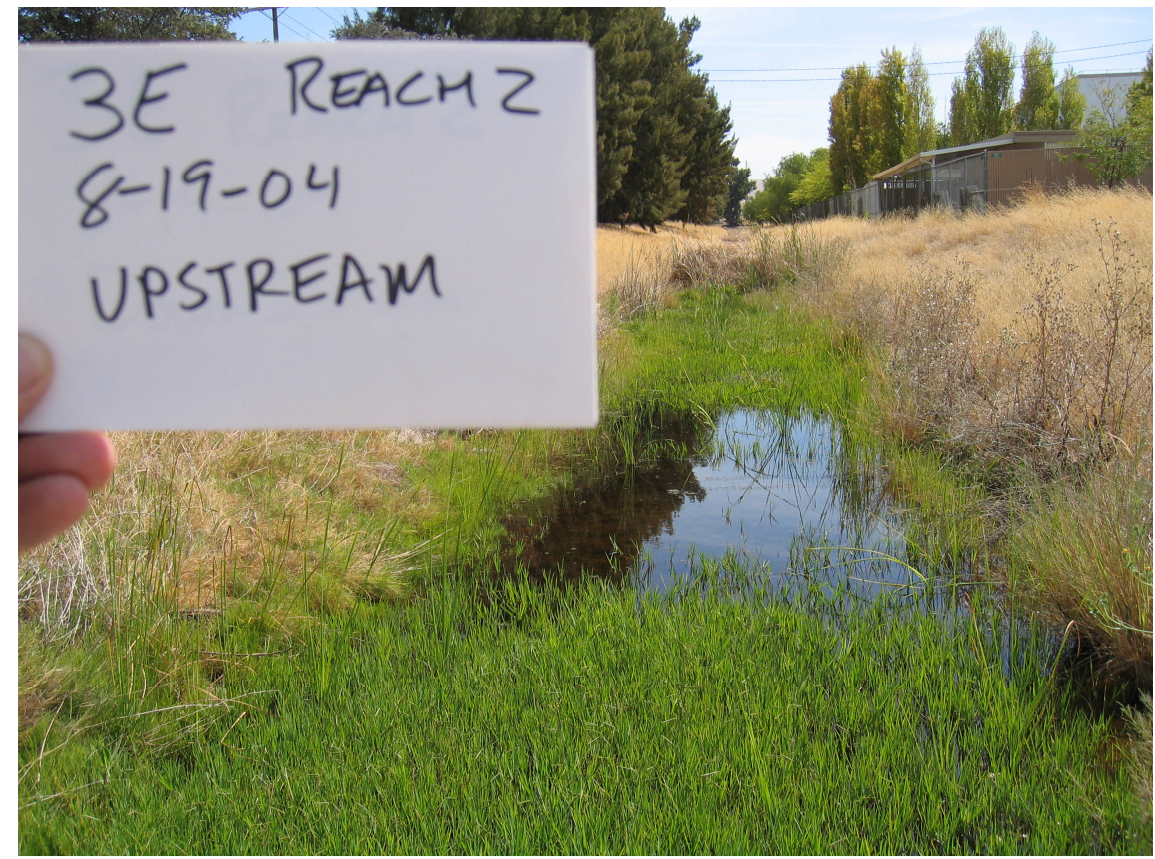

Figure 33. Zone 3E continued to be hydrated into 2004 and began to form patches of Bermuda grass (Cynodon dactylon) with cattail growth. 
2005: Zone 3E, Reach 2

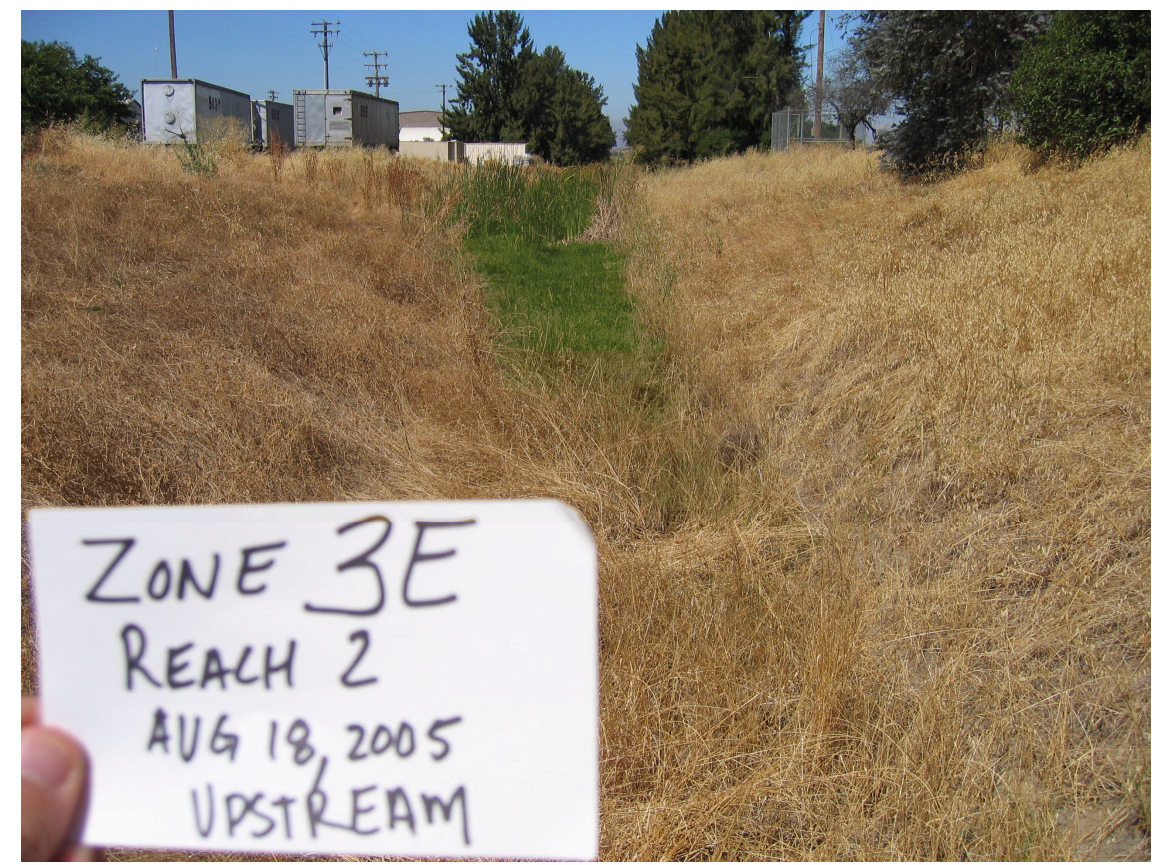

Figure 34. Zone $3 \mathrm{E}$ with annual grass growth consisting mostly of wild oats. Note the identification card is mislabeled as "upstream view," but is actually the downstream view.

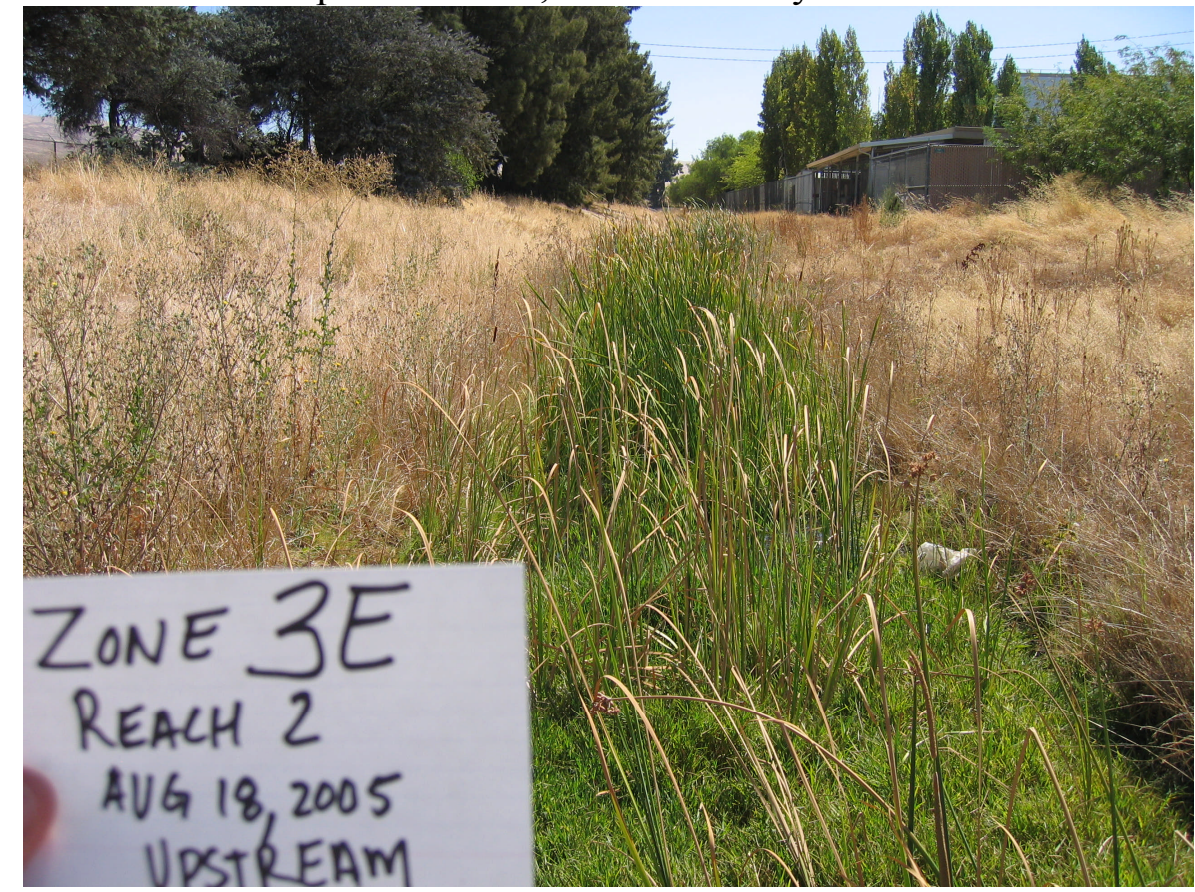

Figure 35. Zone 3E showed substantial cattail growth from previous years. 


\section{0: Zone 3F, Reach 2}

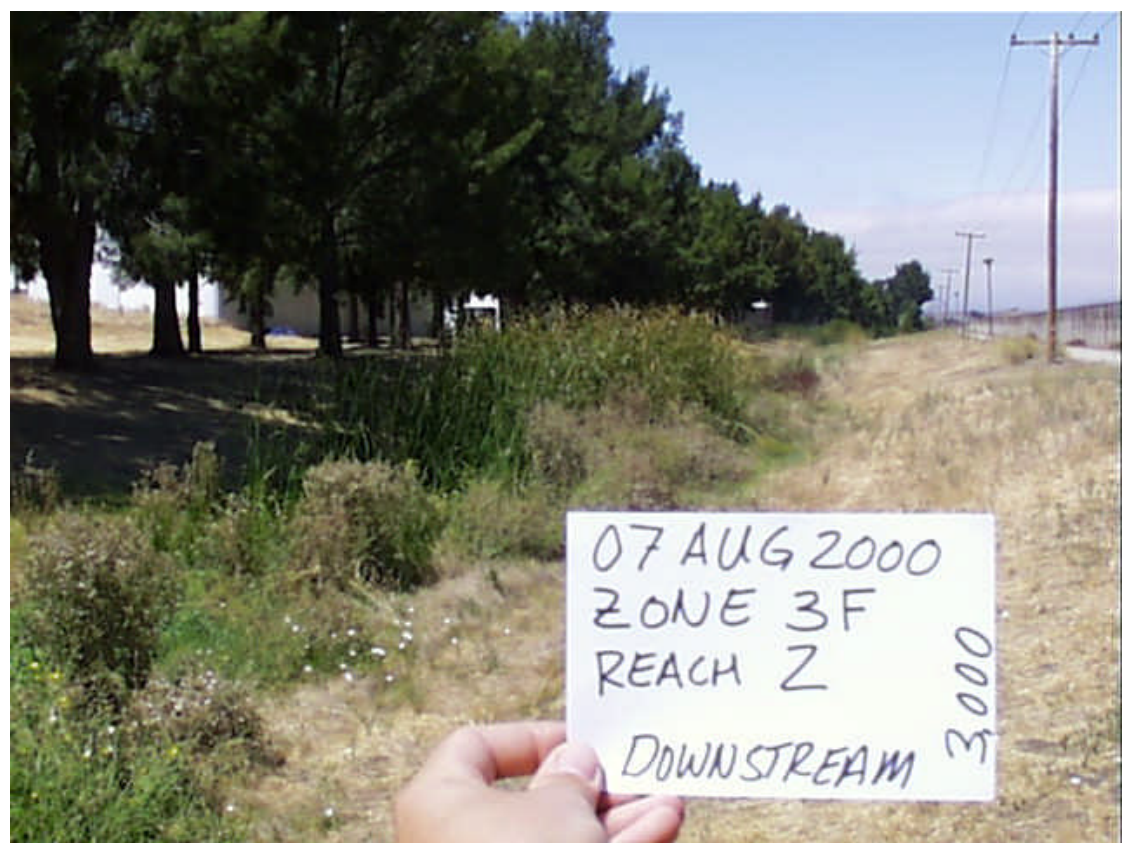

Figure 36. Photograph showing the top of Zone 3F with mature wetland vegetation (downstream view) prior to dredging in 2000. Note large defined patches of cattails and robust herbaceous growth, including spiny sowthistle and tall flatsedge in the foreground. No open water habitat existed in this zone prior to dredging activities.

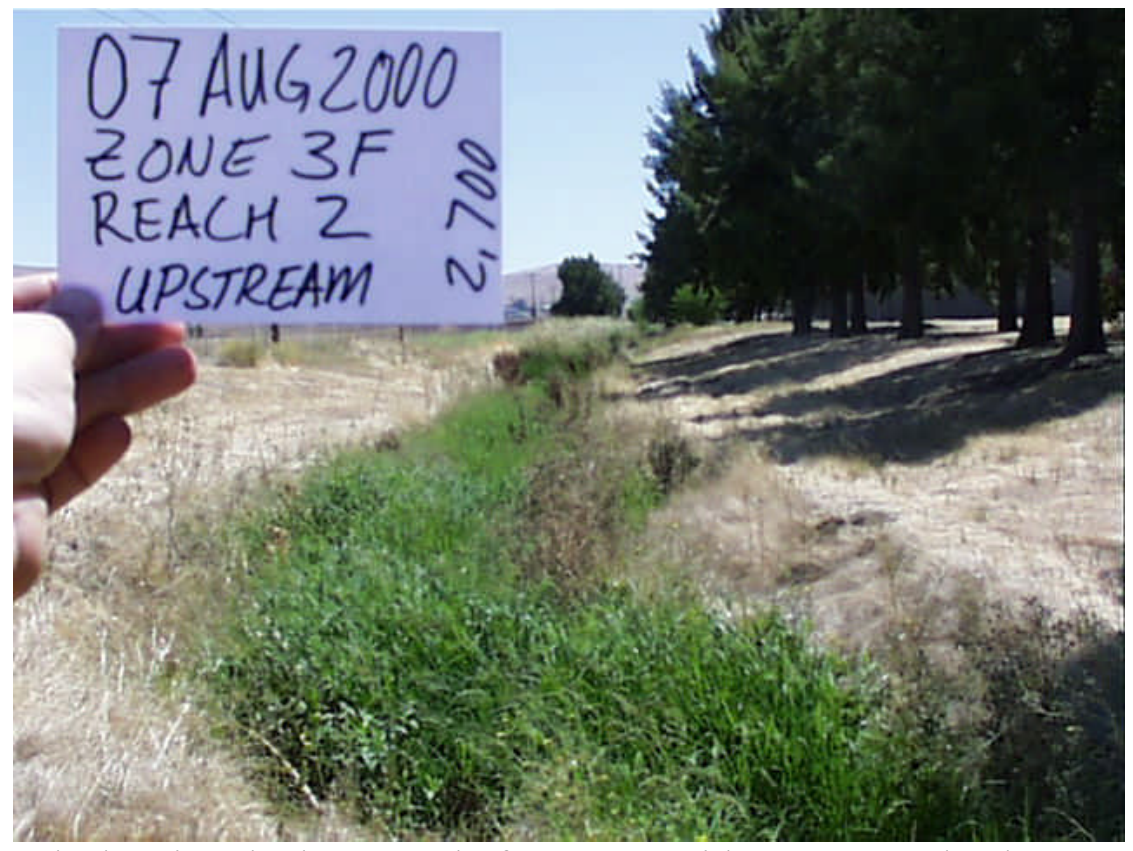

Figure 37. Photograph showing the lower end of Zone 3F with mature wetland vegetation (upstream view) prior to dredging in 2000. Pale smartweed, perennial grasses, and tall flatsedge dominated the lower portion of Zone 3F. No open water habitat occurred in this zone prior to dredging. 
Arroyo Las Positas Maintenance Impact Study

Table 4. Plants found within the wetted portion of the Zone 3F channel prior to dredging in 2000. Dominant species are in bold.

\begin{tabular}{|l|l|}
\hline \multicolumn{1}{|c|}{ COMMON NAME } & \multicolumn{1}{c|}{ SCIENTIFIC NAME } \\
\hline Watercress & Rorippa nasturtium aquaticum \\
\hline Broad-leaved cattail & Typha latifolia \\
\hline Narrow-leaved cattail & Typha angustifolia \\
\hline Spiny sowthistle & Sonchus asper \\
\hline Rabbit's foot grass & Polypogon monspeliensis \\
\hline Alkali bullrush & Scirpus bobustus \\
\hline Dallisgrass & Paspalum dilatatum \\
\hline Tall flatsedge & Cyperus eragrostis \\
\hline
\end{tabular}




\section{1: Zone 3F, Reach 2}

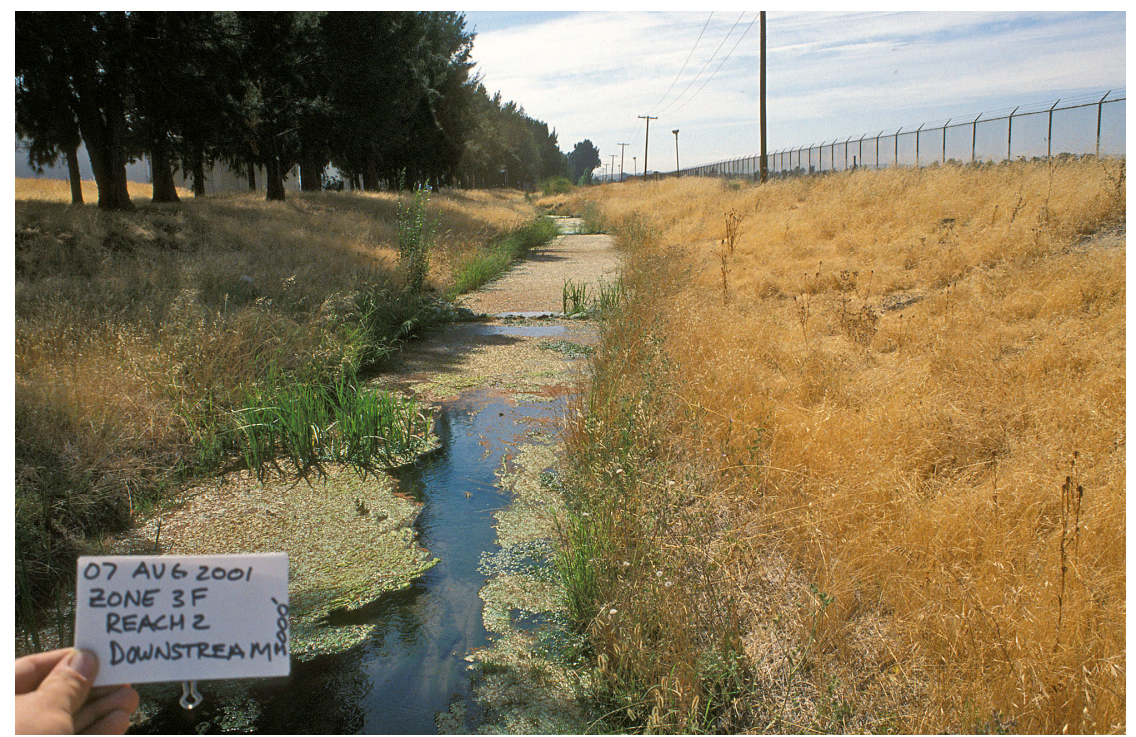

Figure 38. Photograph showing the top of Zone 3F with mature wetland vegetation (downstream view) prior to dredging in 2000. Note large defined patches of cattails and robust herbaceous growth, including spiny sowthistle and tall flatsedge in the foreground. No open water habitat existed in this zone prior to dredging activities.

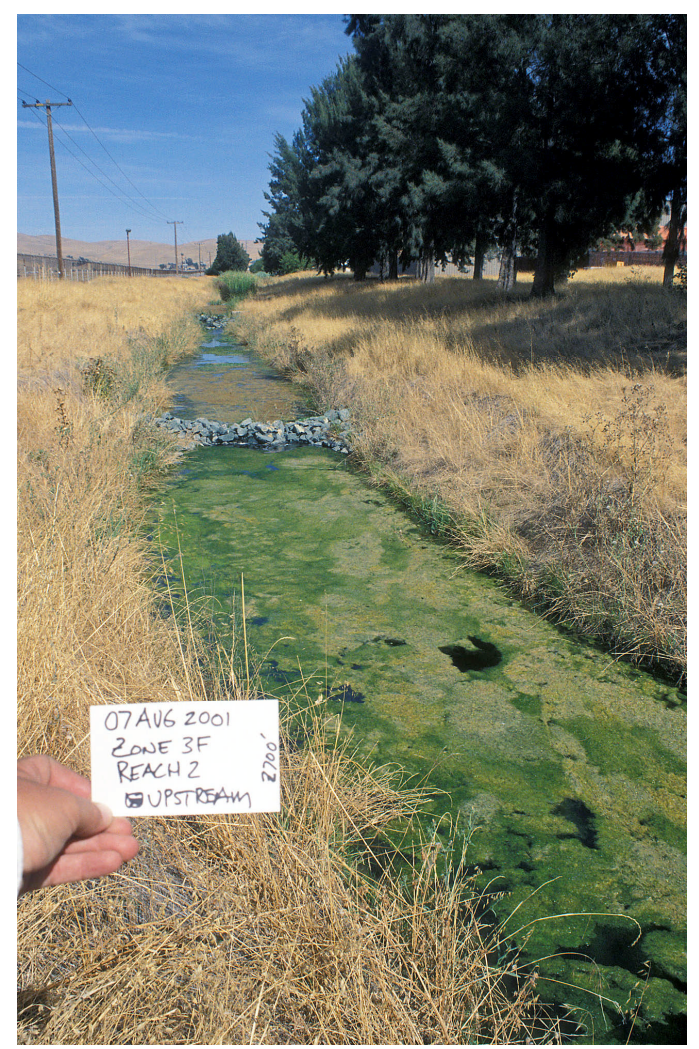

Figure 39. Photograph showing the lower end of Zone 3F (upstream view) with early succession annual and perennial grasses (upstream view). Open water habitat with significant algal growth was the dominant feature in 2001. Note rock weirs used for grade adjustment. 


\section{2: Zone 3F, Reach 2}

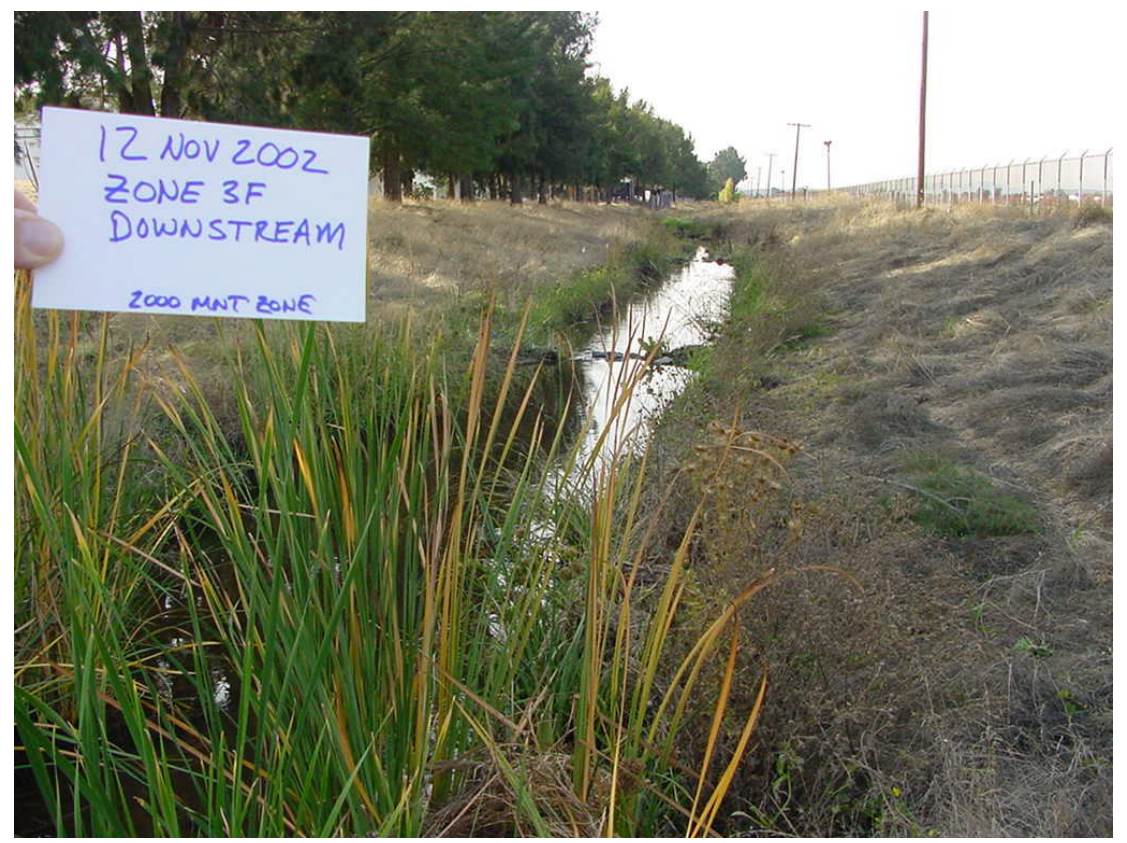

Figure 40. Photograph showing the top of Zone 3F (downstream view) with wetland vegetation reestablishing throughout the littoral zone.

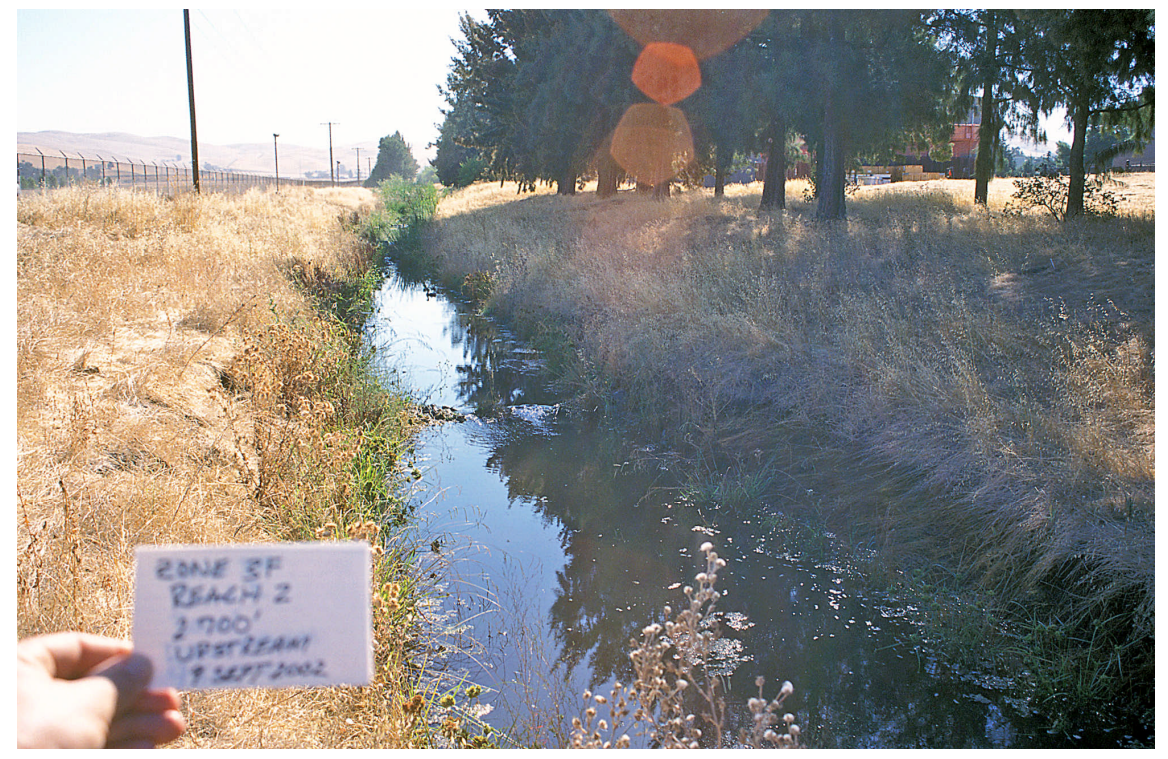

Figure 41. Wetland plants such as tall flatsedge increased in 2002, but remained in a mosaic of annual grasses and spiny sowthistle in the lower portion of 3F. Open water habitat remained prevalent in this portion of the zone. 


\section{3: Zone 3F, Reach 2}

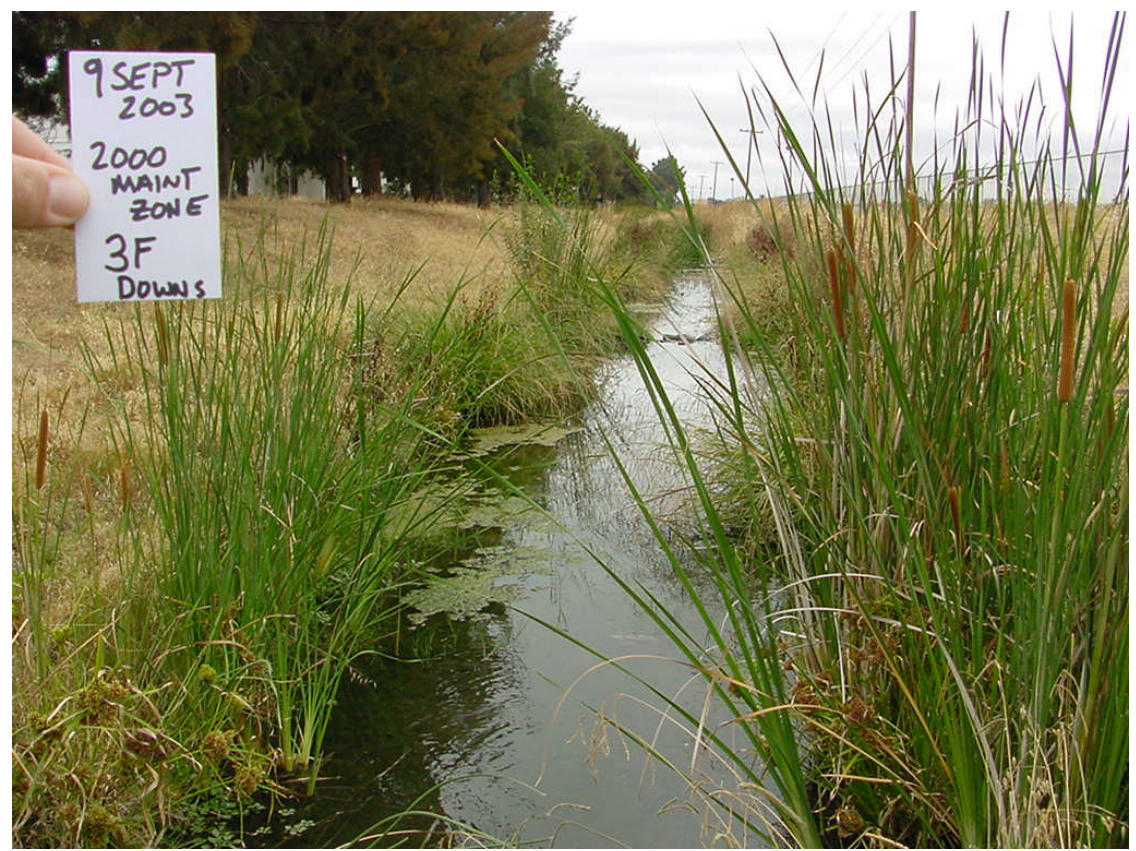

Figure 42. Photograph showing the top of Zone 3F (downstream view) with wetland vegetation established. Important wetland plants such as tall flatsedge were dominant by 2003.

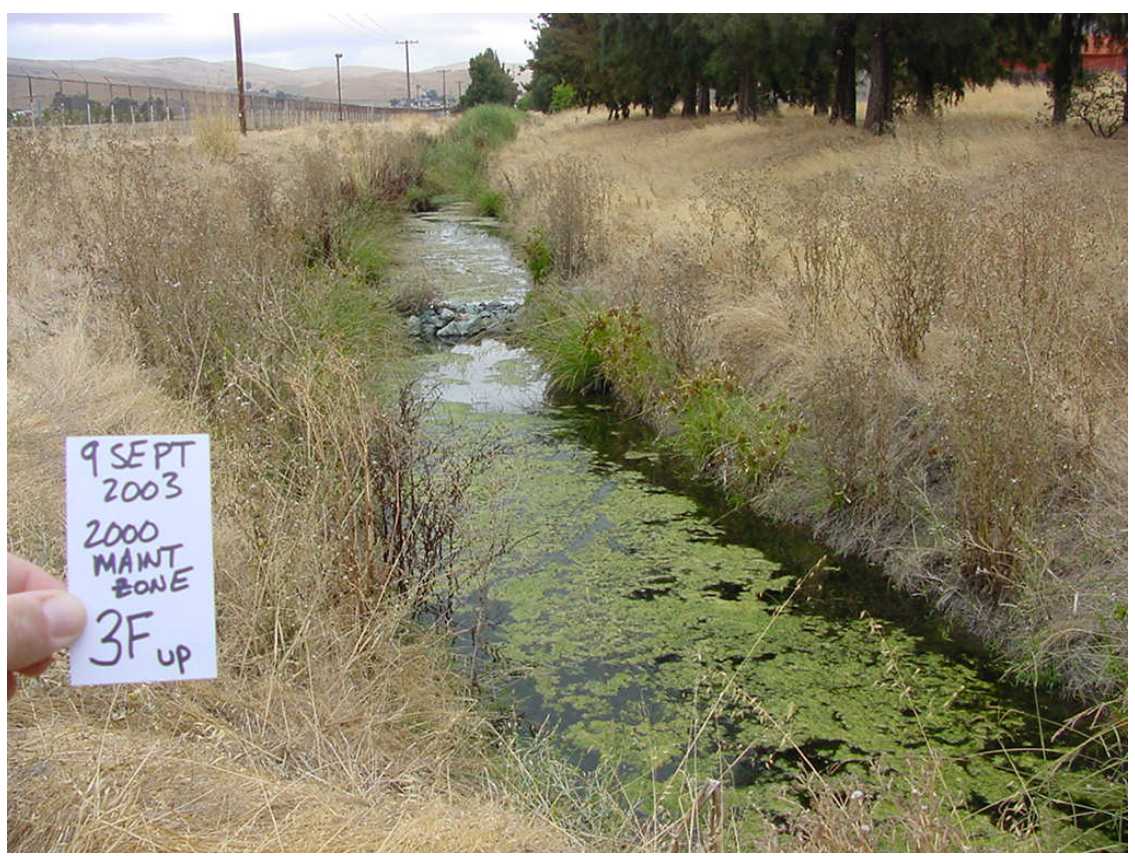

Figure 43. Wetland plants such as tall flatsedge increased by 2003, but still remained patchy as annual grasses and spiny sowthistle were dominant in the lower portion of 3F. Open water habitat remained prevalent in this portion of the zone. 
2004: Zone 3F, Reach 2

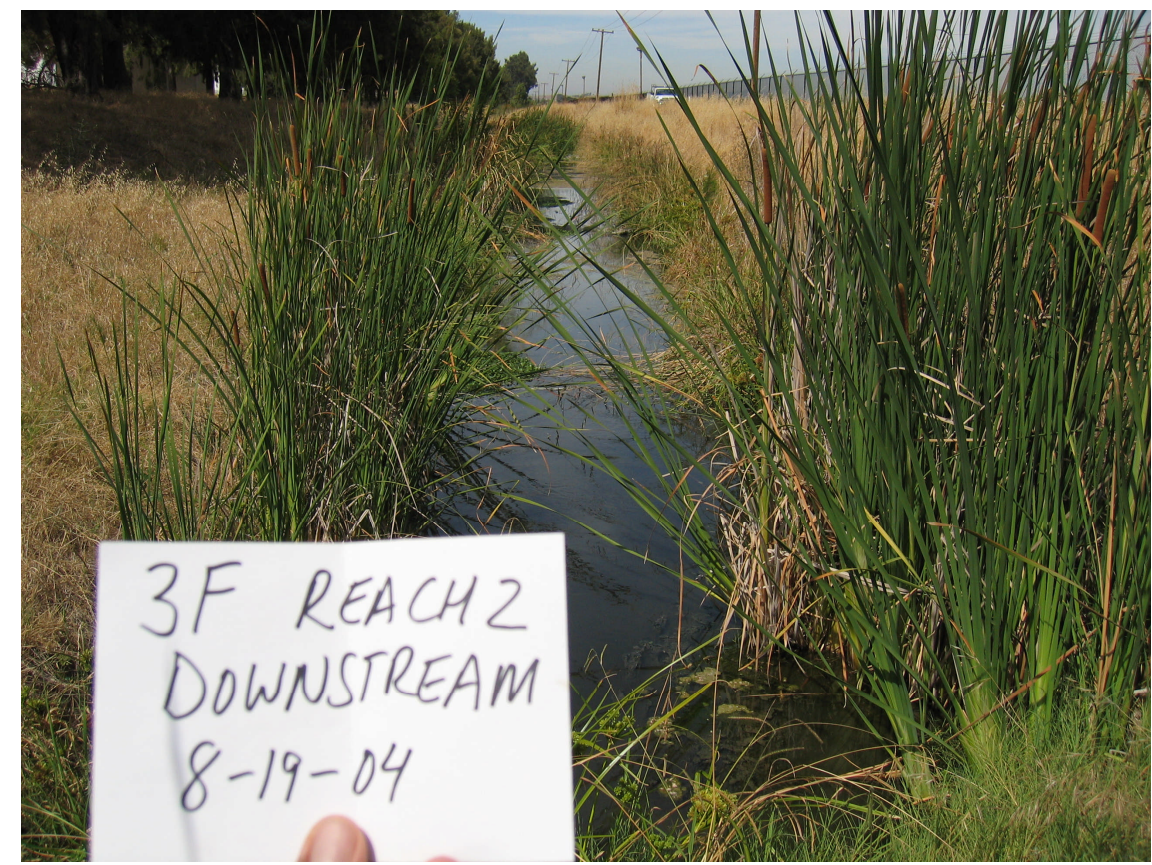

Figure 44. Photograph showing the top of Zone 3F (downstream view) with wetland vegetation established and mature. Important wetland plants such as tall flatsedge were dominant by 2003. Cattails increased in density through this period.

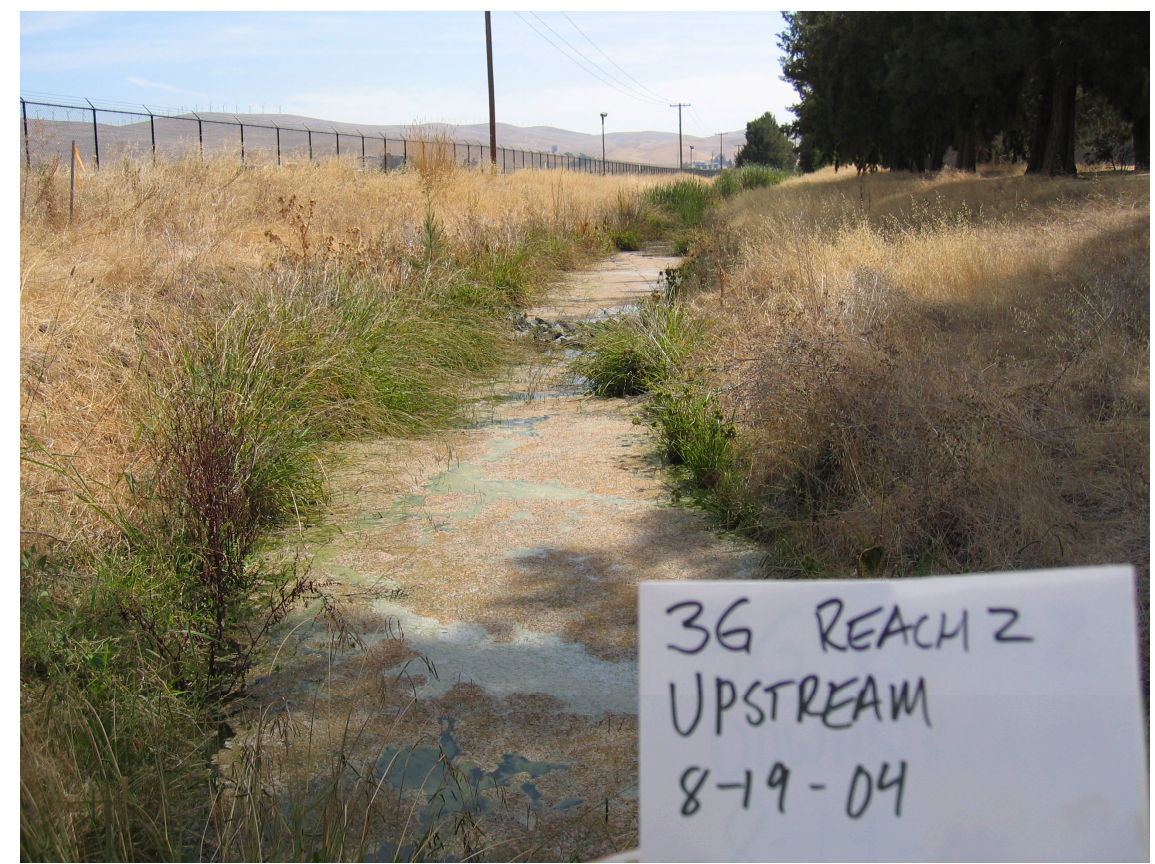

Figure 45. Wetland plants such as tall flatsedge increased by 2004 from 2003, although annual grasses were still prevalent. (Note: Note card is mislabeled as 3G). 
2005: Zone 3F, Reach 2

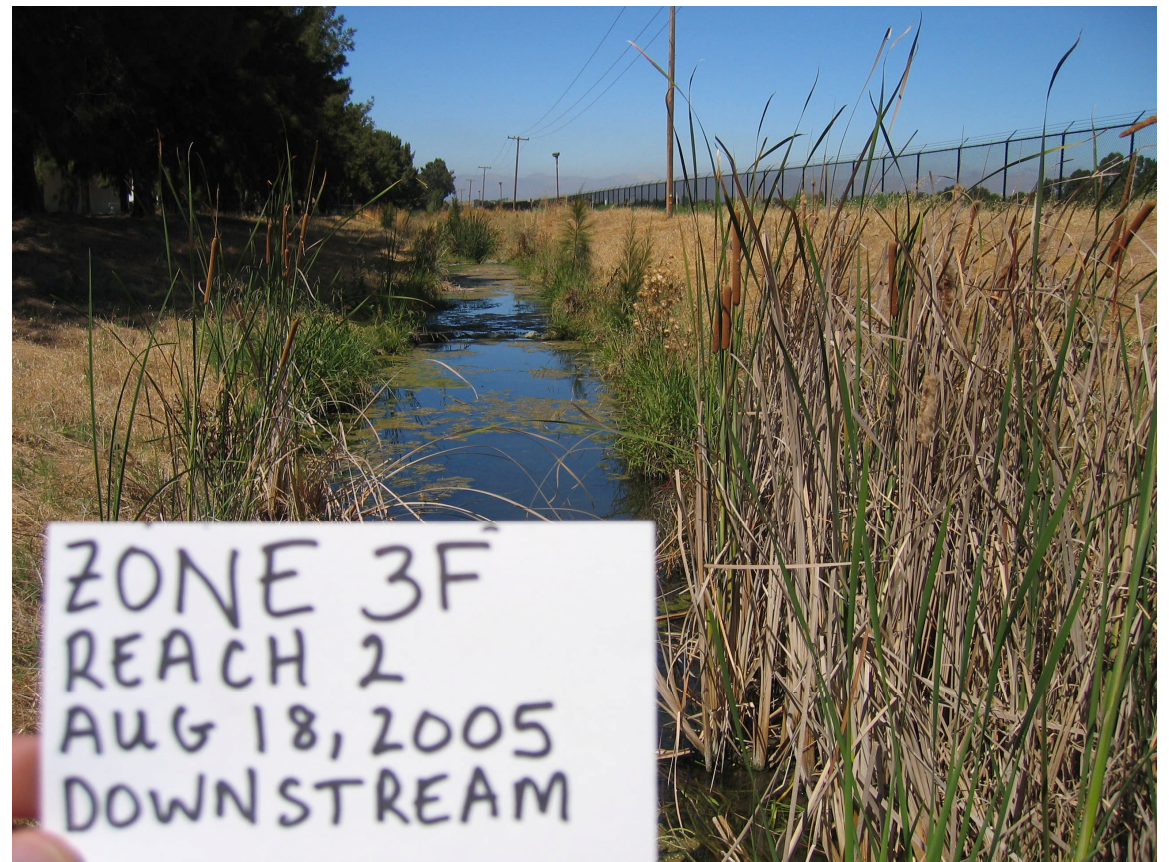

Figure 46. Photograph showing the top of Zone 3F (downstream view) with wetland vegetation established and mature. Wetland features remain essentially unchanged since 2004, with significant open water habitat.

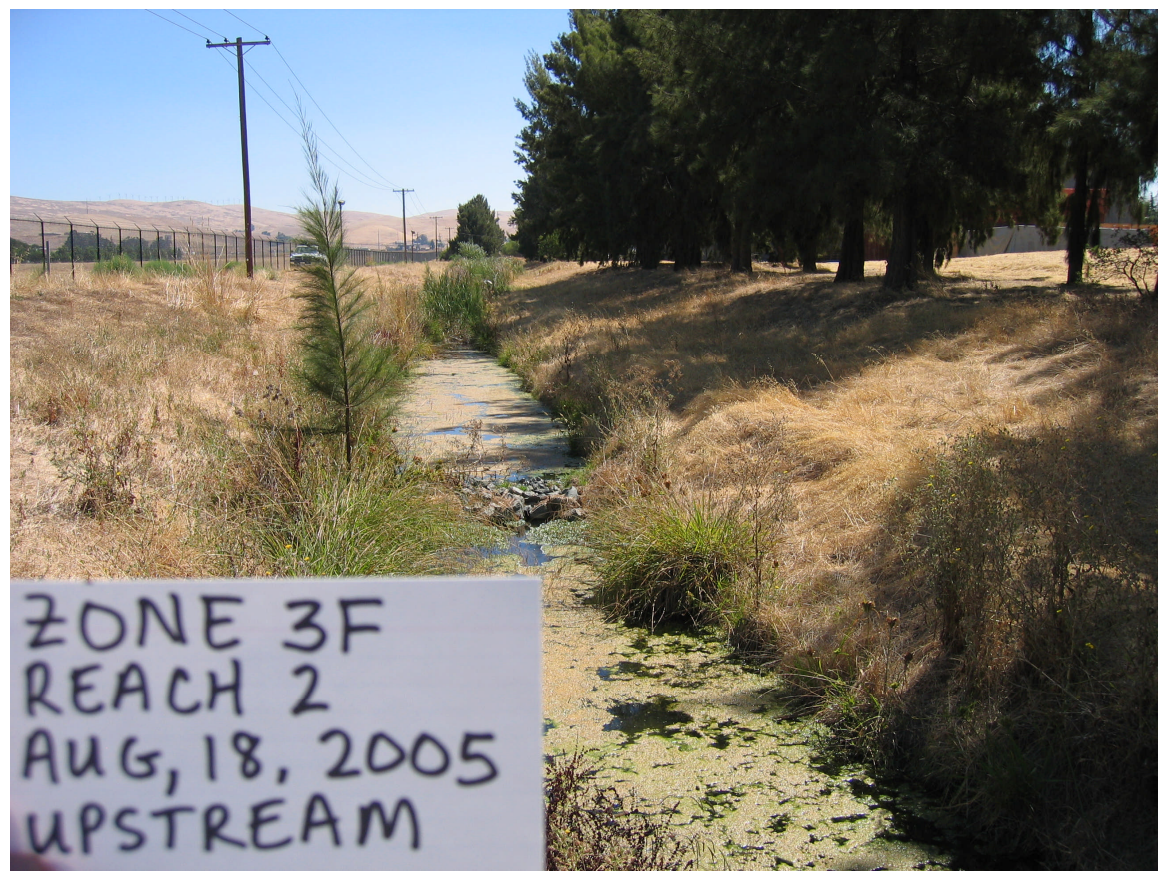

Figure 47. Photograph showing the lower portion of $3 \mathrm{~F}$ (upstream view), essentially unchanged from previous years. 


\section{0: Zone 3G, Reach 2}

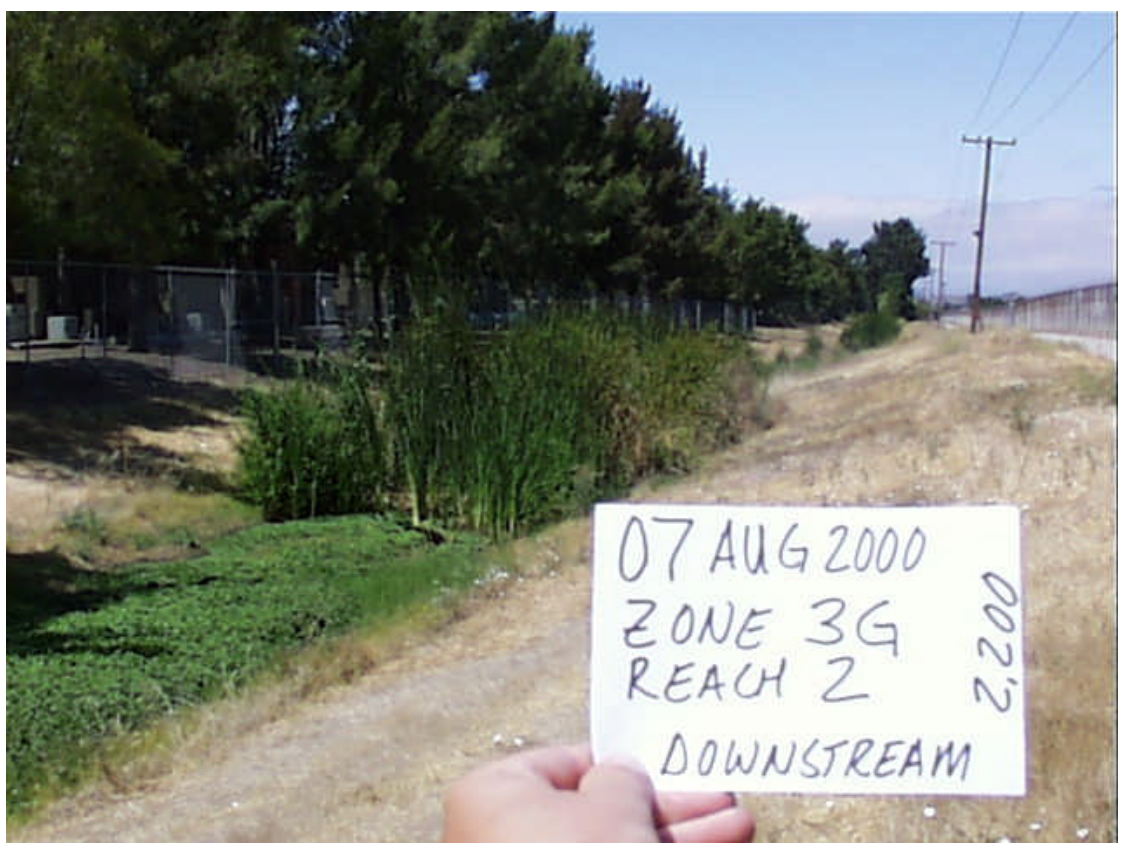

Figure 48. Photograph showing the top of Zone $3 \mathrm{G}$ with mature wetland vegetation (downstream view) prior to dredging in 2000. Note large defined patches of watercress and cattails, and mowed upper banks with no open water habitat.

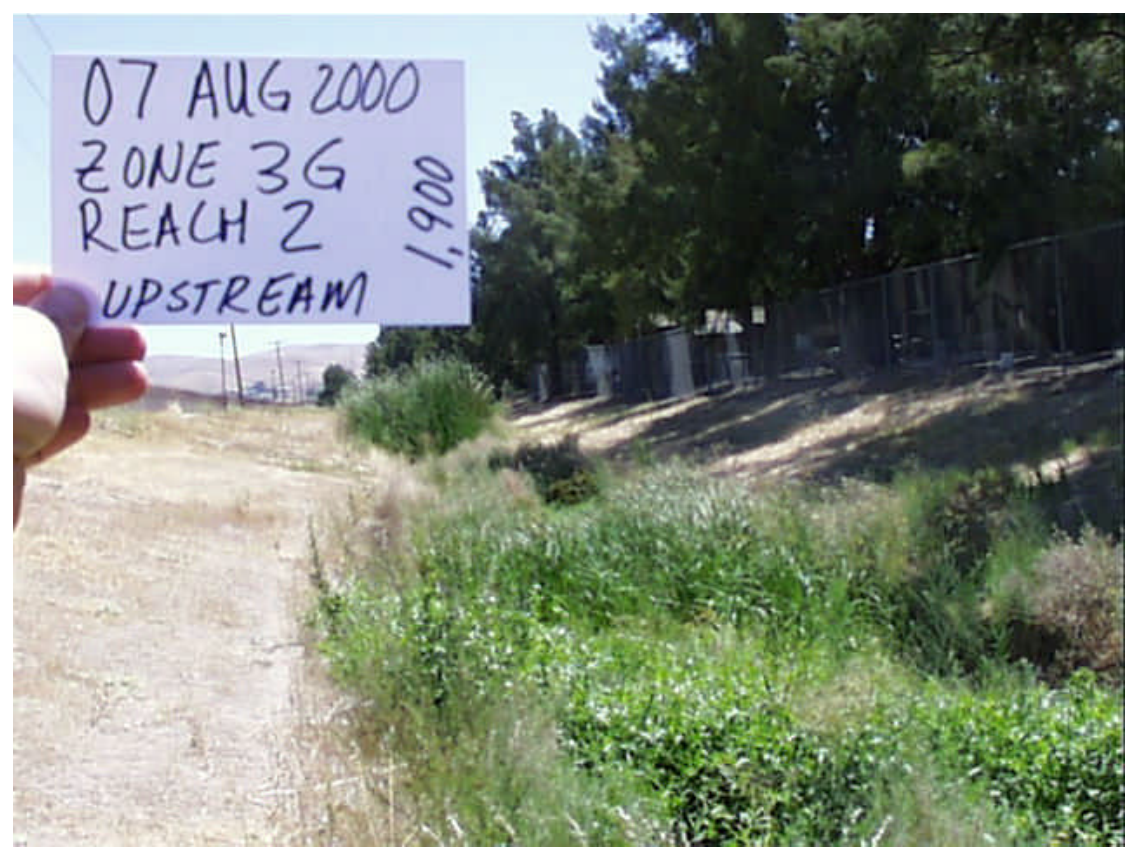

Figure 49. Photograph showing the lower end of Zone $3 \mathrm{G}$ with mature wetland vegetation (downstream view) prior to dredging in 2000. Pale smartweed and watercress in addition to perennial grasses and tall flatsedge (Table 5) dominated the lower portion of Zone 3G. No open water habitat occurred in this zone prior to dredging. 
Table 5. Plants found within the wetted portion of the Zone $3 \mathrm{G}$ channel prior to dredging in 2000. Dominant species are in bold.

\begin{tabular}{|l|l|}
\hline \multicolumn{1}{|c|}{ COMMON NAME } & \multicolumn{1}{c|}{ SCIENTIFIC NAME } \\
\hline Horseweed & Conyza canadensis \\
\hline Broad-leaved cattail & Typha latifolia \\
\hline Alkali bullrush & Scirpus bobustus \\
\hline Watercress & Rorippa nasturtium aquaticum \\
\hline Dallisgrass & Paspalum dilatatum \\
\hline Broad-leaved cattail & Typha latifolia \\
\hline Curly dock & Rumex crispus \\
\hline Clustered dock & Rumex conglomeratus \\
\hline Pale smartweed & Polygonum lapathifolium \\
\hline Saltbush & Atriplex triangularis \\
\hline Tall flatsedge & Cyperus eragrostis \\
\hline Spiny sowthistle & Sonchus asper \\
\hline Barnyard grass & Echinochloa crus-galli \\
\hline Mosquito fern & Azolla filiculoides \\
\hline Rabbit's-foot grass & Polypogon monspeliensis \\
\hline Alkali bulrush & Scirpus robustus \\
\hline Hairy vetch & Vicia villosa \\
\hline Black mustard & Brassica nigra \\
\hline Wild oats & Avena fatua \\
\hline Saltgrass & Distichilis spicata \\
\hline Turkey mullein & Eremocarpus setigerus \\
\hline Field binweed & Convolvulus arvensis \\
\hline
\end{tabular}

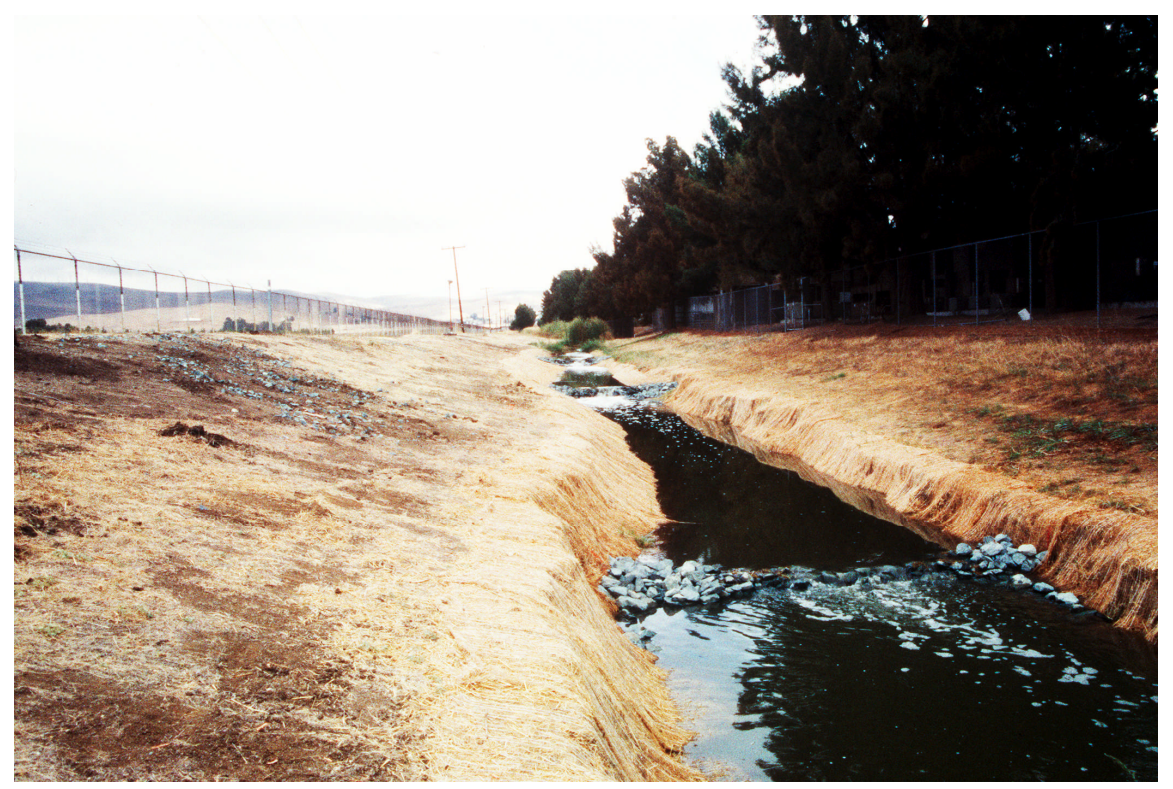

Figure 50. Photograph of $3 \mathrm{G}$ after dredging activity during initial precipitation of the year. Note erosion control blankets used for bank stabilization and rock weirs used for grade adjustment. 


\section{1: Zone 3G, Reach 2}

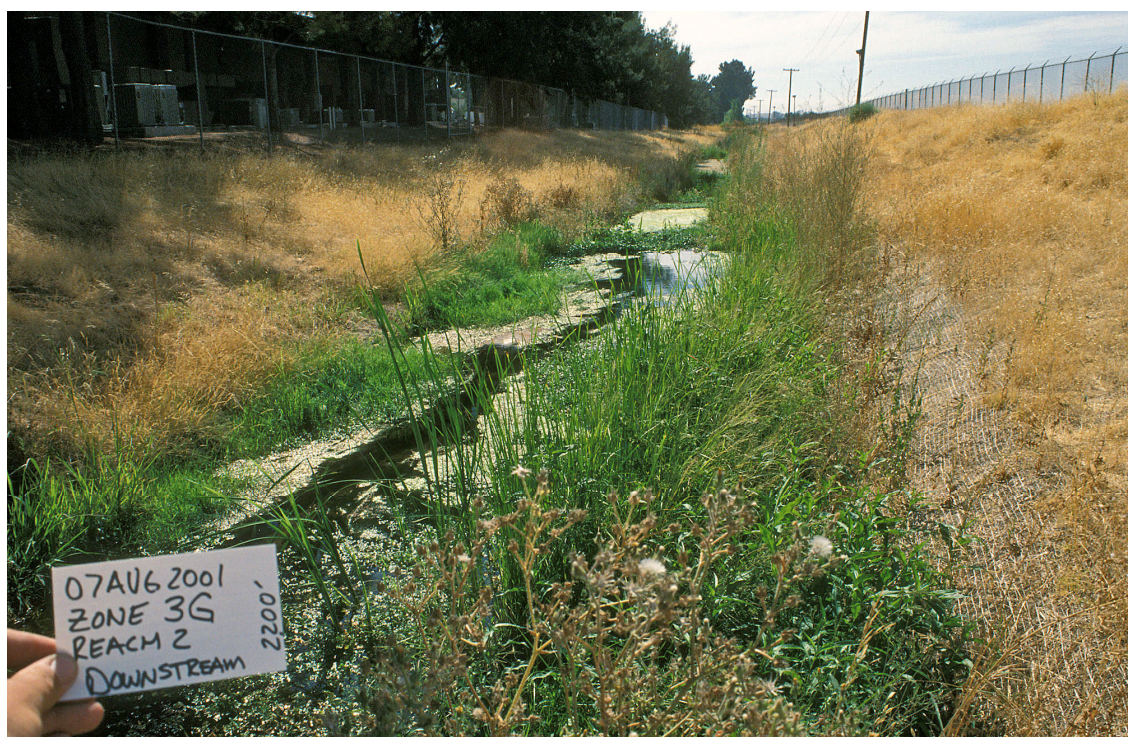

Figure 51. Photograph showing the upper end of Zone 3G (downstream view) a year after dredging with hydrophytes re-colonizing and well established. As expected, hydrophyte diversity was similar, but less robust post dredging (early succession stage), and open water habitat was created.

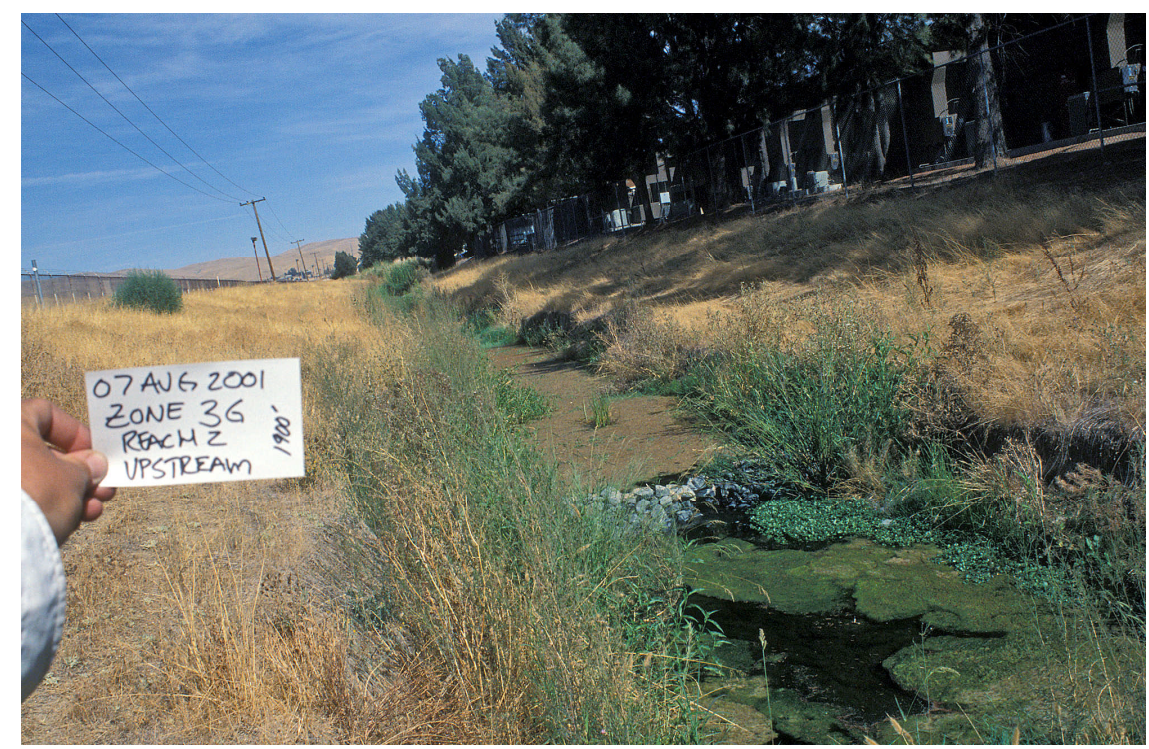

Figure 52. Photograph showing the lower end of Zone 3G (upstream view) a year after dredging with hydrophytes re-colonizing and well established. As expected, hydrophyte diversity was similar, but less robust post dredging (early succession stage), and open water habitat was created. 


\section{2: Zone 3G, Reach 2}

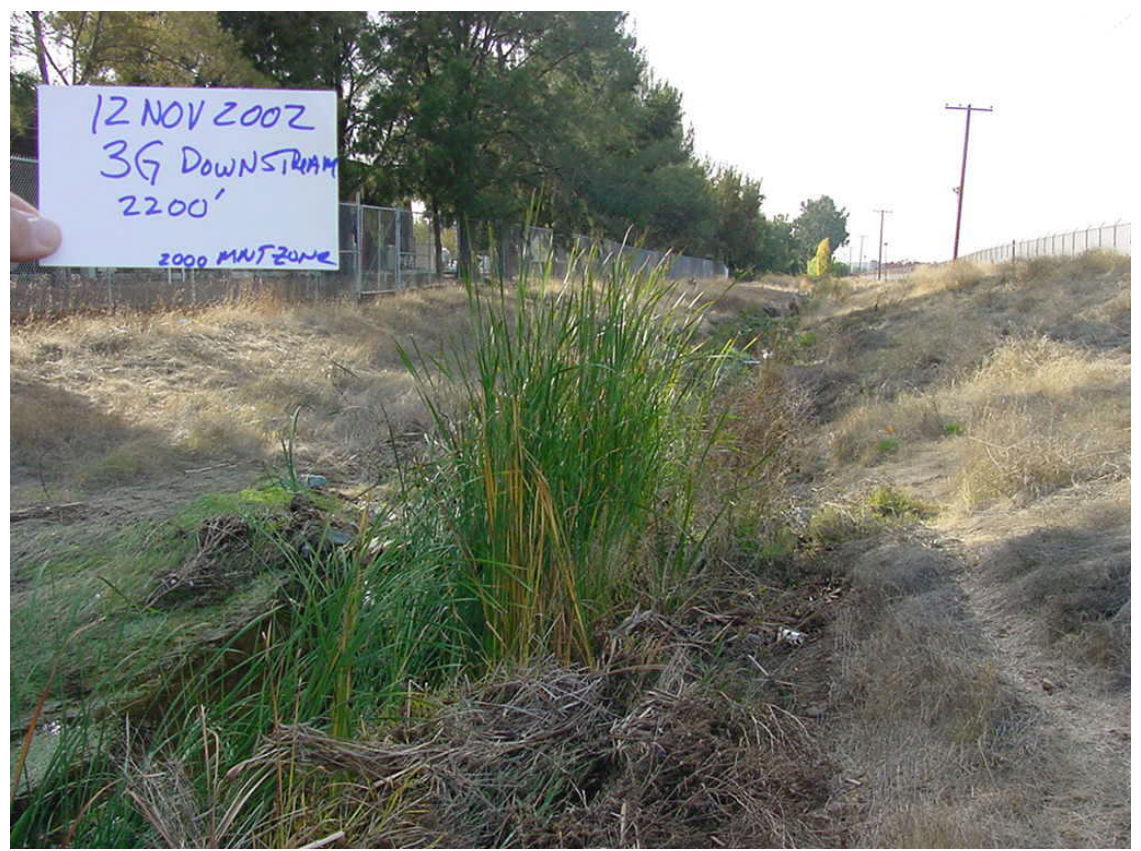

Figure 53. Photograph showing the upper end of Zone $3 \mathrm{G}$ (downstream view) two years after dredging with hydrophytes re-colonizing and well established. The only visible vegetative change during this period was the re-establishment of cattails.

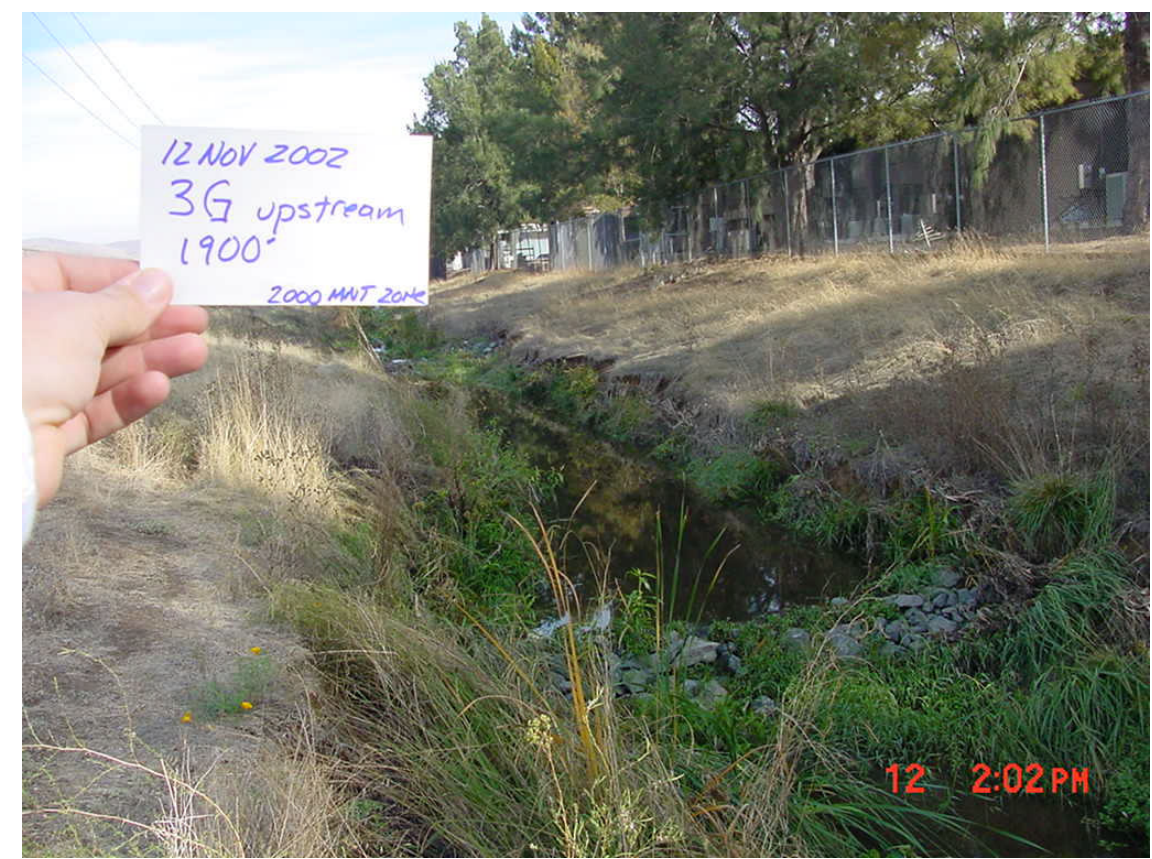

Figure 54. Photograph showing the lower end of Zone 3G (upstream view) two years after dredging with hydrophytes re-colonizing and well established. As expected, hydrophyte diversity was similar, but less robust post dredging (early succession stage), and open water habitat was created. 


\section{3: Zone 3G, Reach 2}

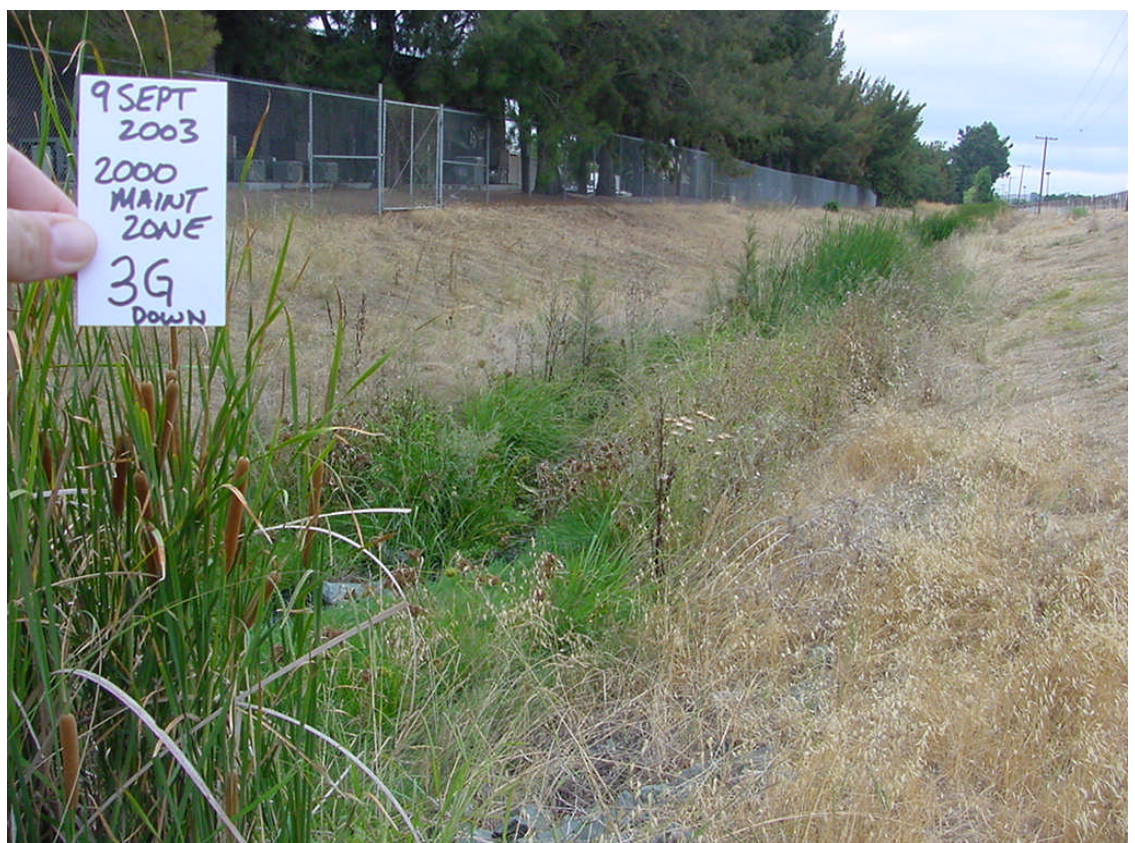

Figure 55. Photograph showing the upper end of Zone 3G (downstream view) three years after dredging with hydrophytes well established. Cattail establishment continued during this period.

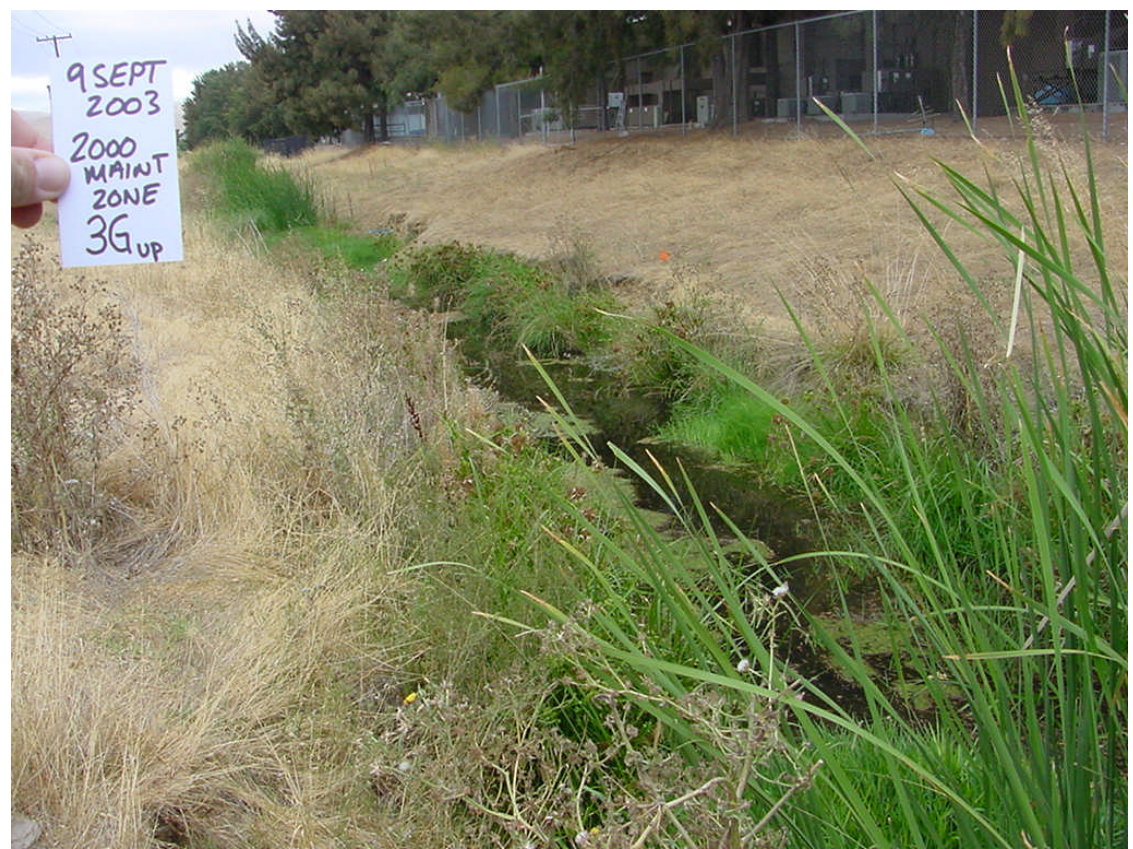

Figure 56. Photograph showing the lower end of Zone 3G (upstream view) three years after dredging with hydrophytes established and closing in on open water habitat. 


\section{4: Zone 3G, Reach 2}

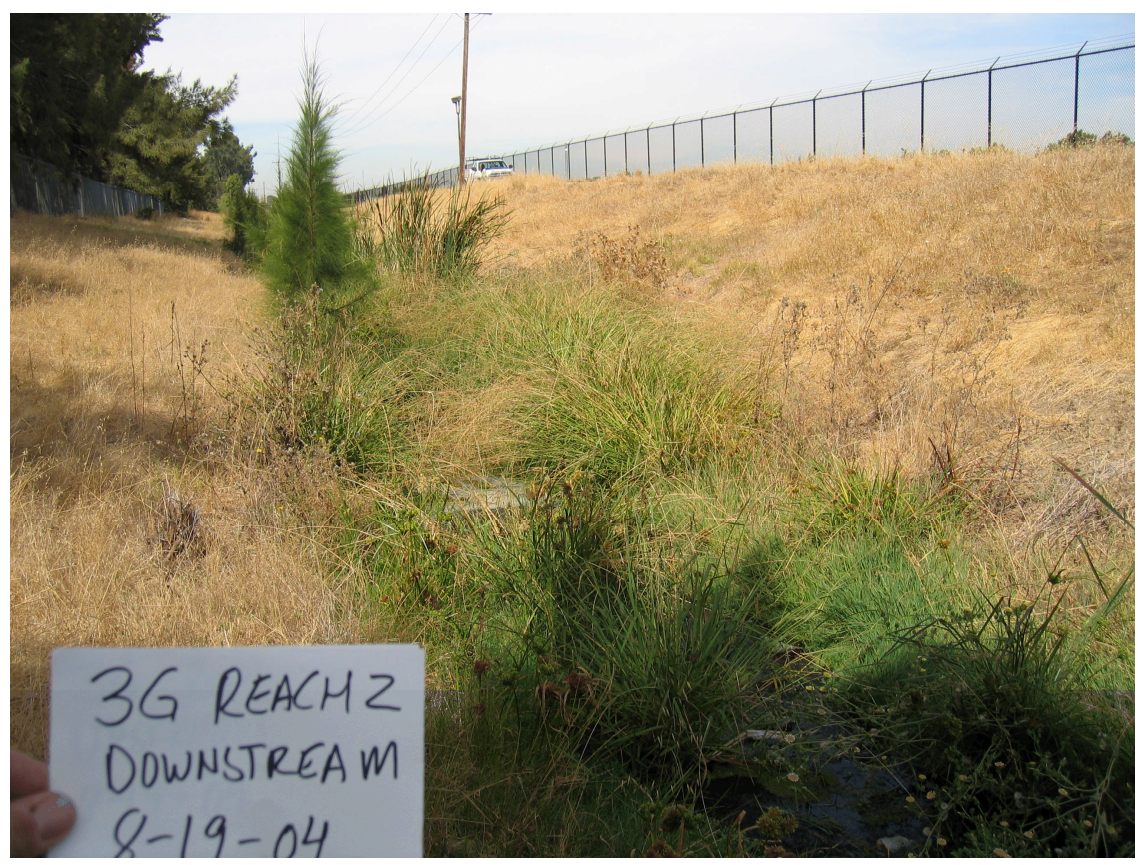

Figure 57. Photograph showing the upper end of Zone 3G (downstream view) four years after dredging with hydrophytes well established with less open water habitat. Note the establishment of volunteer Australian pines (Cassaurina sp.) from the adjacent tree line.

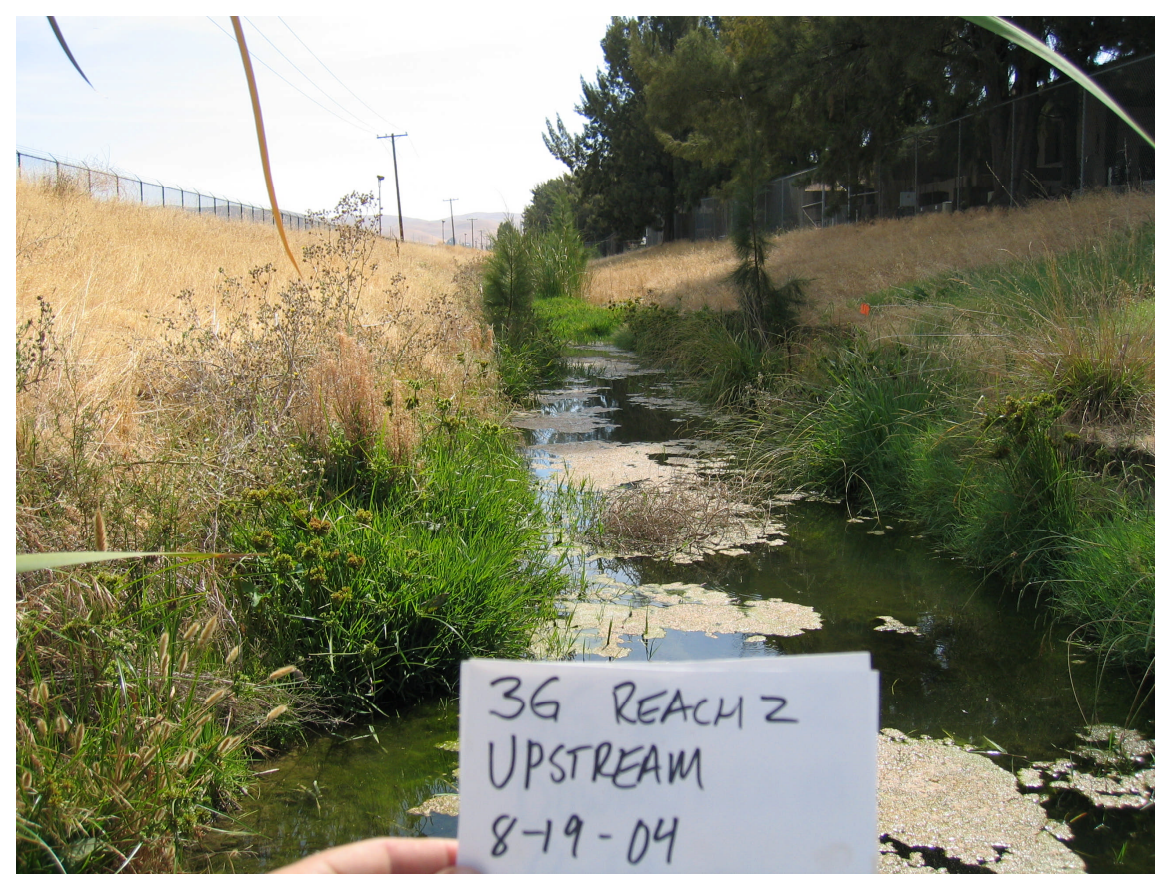

Figure 58. Photograph showing the lower end of Zone 3G (upstream view) three years after dredging with hydrophytes established. Important plants such as tall flatsedge dominate the open water littoral zone of the lower reach. Additionally, red swamp crayfish (Procambarus clarkii) became established in the ALP during 2004 and now may be a contributing factor to the openness of Zone 3G. 


\section{5: Zone 3G, Reach 2}

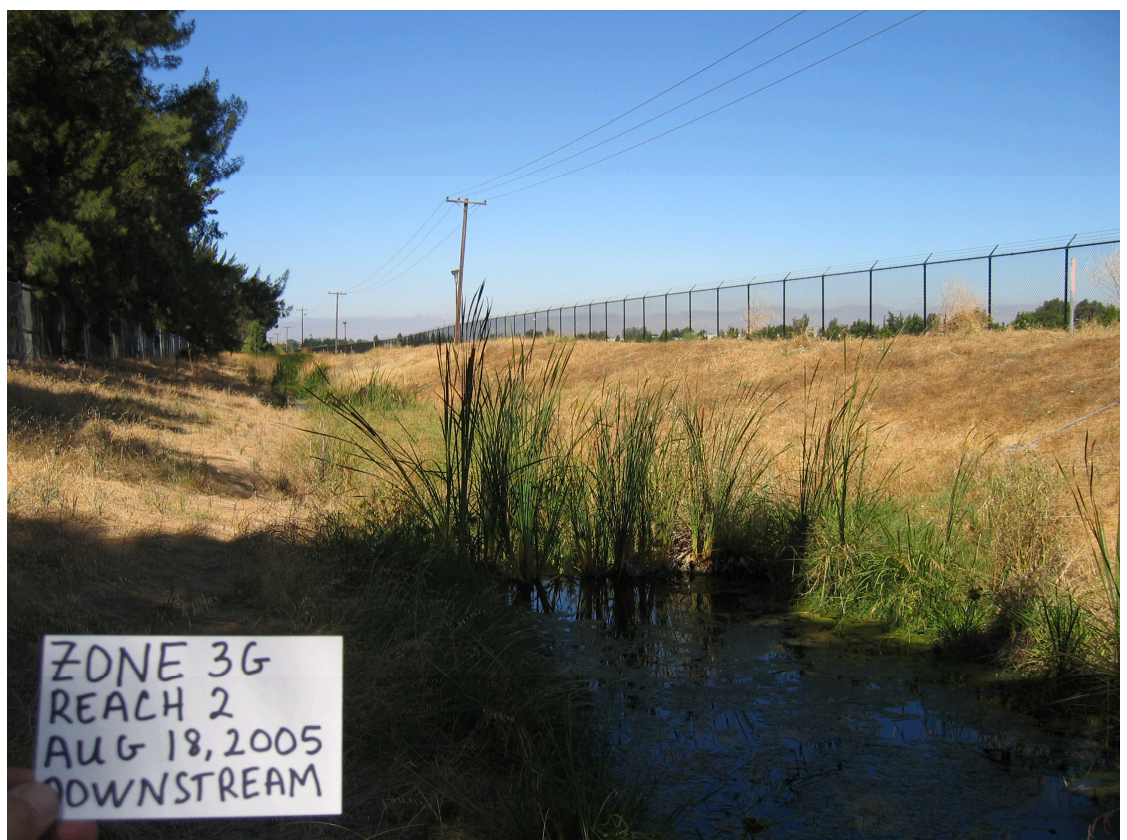

Figure 59. Photograph showing the upper end of Zone 3G (downstream view) five years after dredging with hydrophytes well established.

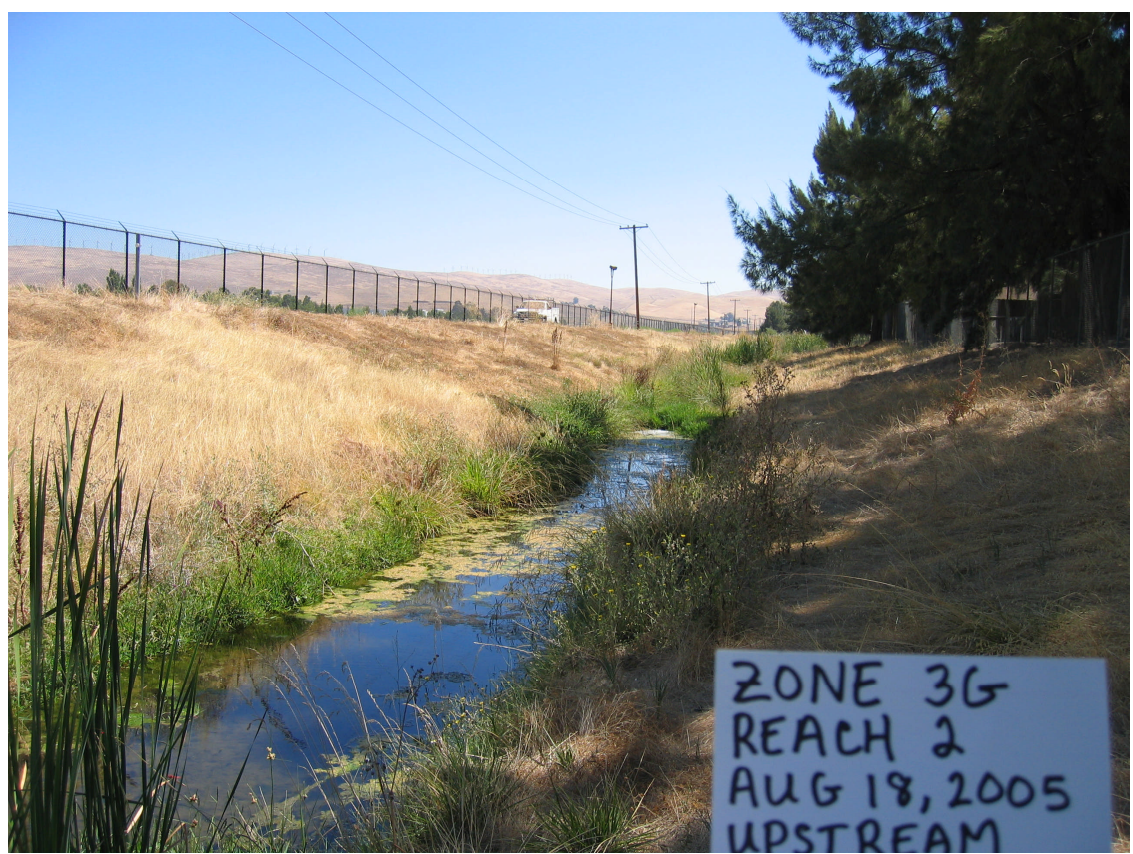

Figure 60. Photograph showing the lower end of Zone 3G (upstream view) five years after dredging with hydrophytes established. 


\section{Discussion}

\section{R. a. draytonii Population Monitoring}

Vegetation sampling showed that the egg masses found in Arroyo Las Positas occur in areas with less than $20 \%$ cover of emergent wetland species, adjacent to stream banks dominated by a vegetation of annual grasses and forbs. One small reach of Arroyo Las Positas did have an overstory of riparian trees, but $94 \%$ of egg masses were found in areas of no tree or shrub cover. Oviposition sites were shallow (22.86 \pm 9.40 depth at egg mass), close to shore, and near the surface. Urban lotic systems can vary in suitability and sustainability based on biotic, abiotic, and anthropogenic factors. Nevertheless, $R$. $a$. draytonii are capable of breeding successfully in shallow, dynamic, and historically disturbed aquatic systems. The results from this study are of importance to regional conservation planning efforts such as defining and implementing critical habitat criteria.

The distribution of egg masses in the Arroyo Las Positas showed changes over the monitoring period that appears to be a result of dredging activities. Dredging in 2002 allowed water to freely drain out of Reach 1 resulting in less ponded water for shorter durations than previous years. As a result, the number of egg masses in Reach 1 dropped sharply in 2003 and 2004. Alternatively, dredging enhanced breeding pools in Reach 2. Despite changes in the location of breeding habitat, the number of egg masses in the entire LLNL reach of Arroyo Las Positas remained similar in 2001, 2002, and 2003. The total number of egg masses in the entire LLNL reach of Arroyo Las Positas dropped sharply in 2004 from previous years. This decrease is most likely the result of factors other than dredging conducted in the Arroyo Las Positas because no dredging was conducted for two years prior to the 2004 breeding season, although dredging had occurred the summer before each of the other breeding seasons included in this study.

\section{Macro-Invertebrate Monitoring}

Macro-invertebrate abundance in the control site (Zone 1H) decreased in October 2000 from baseline levels measured in June and July of 2000. Abundance rose gradually in subsequent years at the control site. Zones $3 \mathrm{~F}$ and $3 \mathrm{G}$ showed a similar trend in macro-invertebrate abundance despite dredging conducted in the summer of 2000. The pattern of abundance of macro-invertebrates in Zone 3E differed from the control site in that abundance rose slightly in October 2000 immediately following dredging, then declined sharply in October of 2001, and increased again in following years. Although no statistical comparison of abundance in the control versus the dredged zones were conducted, the trend of macro-invertebrate abundance does not appear to have been changed as a result of dredging.

The number of families present in the control site increased in October 2000, decreased to pre-project levels in October 2001, and gradually increased in following years. Zone 3G showed a similar trend as the control, but the number of macro-invertebrate families decreased in Zones 3E and 3F immediately after dredging, followed by an increase in the number of families in later years to pre-project levels or greater. Although the number of families in Zones 3E and 3F decreased immediately following dredging, the diversity in families increased to pre-dredging levels in the subsequent years. 


\section{Vegetation Re-establishment}

In 2000, Zone 3C (including 1D, 2A, and 1C) was a uniform, contiguous stand of cattails. The vegetation within this zone presented a significant flow restriction to the Arroyo Las Positas as it entered the Livermore Site. The stand of cattails likely took many years to form since this section of the Arroyo Las Positas is not augmented by CERCLA effluent and therefore is highly ephemeral. A contributing factor to the formation of this stand was likely the above-average precipitation levels associated with El Niño in 1998.

As shown in the 2003 photographs, some level of water management occurs where the Arroyo Las Positas enters the Livermore Site in Reach 1. This zone was hydrated in 2003, but in subsequent years was dry.

Diversity in $3 \mathrm{E}$ was historically low and more representative of what the Arroyo Las Positas would look like without CERCLA effluent (i.e., discharge occurs downstream of Zone 3E). Zone 3E is mostly ephemeral with natural flow only occurring during annual precipitation events. With the exception of stormwater drain discharge, Zone $3 \mathrm{E}$ would likely only contain exotic annual grasses. The wetland plant diversity found in 2000 prior to dredging was probably a function of post 1998 El Niño hydration, where flow and saturation occurred for a prolonged period to allow establishment of species such as alkali bulrush, rabbitfoot polypogon, clustered dock, and cattail in the lower portion of the zone.

Wetland diversity pre-and post dredging was similar throughout the monitoring period. As would be expected, plant communities changed through natural succession as rapidly colonizing species such as annual forbs and grasses rapidly became established while sedges were slower initially, but ultimately became established and currently dominate the littoral make up of Zone 3F. Although 3F is perennially wet like $3 \mathrm{G}, 3 \mathrm{~F}$ was slower to reestablish dense foliage and remains relatively open, which is beneficial to both California red-legged frogs and flow passage.

Between 2003 and 2004, the amount of open water habitat in $3 \mathrm{G}$ increased. A contributing variable that represents a significant change to perennial zones is the spread and establishment of red swamp crayfish. Crayfish are primarily herbivores, but opportunistically scavenge and prey upon fish and early life stages of amphibians. Theoretically, crayfish foraging may drive the resurgence of open water characteristics seen around the later monitoring periods. 
Arroyo Las Positas Maintenance Impact Study

\section{APPENDIX A}




\section{MAINTENANCE IMPACT STUDY PLAN \\ WDR 99-086}

\section{Summary}

This plan identifies certain sub-elements of the permit provision \#19 commitment related to monitoring wildlife and habitat changes relative to the Arroyo Las Positas Maintenance Project. These elements specify additional detail for these activities as noted in Provision 19 of WDR 99-086. Documentation will record the status of three biological variables during the next five years of maintenance activities: California red-legged frog (Rana aurora draytonii) (R. a. draytonii) population, macro-invertebrate community, and wetland vegetation.

Outlined below is the more detailed methodology.

\section{Background}

Provision 19 of the Waste Discharge Requirement (WDR) states:

"The Discharger shall submit a Final Plan, acceptable to the Executive Officer, for the Maintenance Impact Study (Study) no later than June 1, 2000. The Plan shall include a detailed description of the proposed annual monitoring, including: assessments of $R$. a. draytonii presence and distribution; macroinvertebrate species richness; and vegetation colonization and establishment. At a minimum, the plan shall include provisions for:

d. R. a. draytonii monitoring, including seasonal nocturnal surveys;

e. Macro-invertebrate monitoring, including pre- and post-activity sampling in each of the areas desilted and in a control location; and,

f. Wetland vegetation establishment, including a comparison of annual growth and species diversity."

The requirements of Provision II (a) are addressed in item 1. The requirements of Provision II (b) are addressed in item 2. The requirements of Provision II (c) are addressed in item 3.

\section{R. a. draytonii Population Monitoring}

Adult $R$. a. draytonii breeding presence (distribution) and activity levels in the LLNL Livermore site portion of the Arroyo Las Positas will be collected during the breeding period (generally March of any given year). Attention would be given to compare $R$. $a$. draytonii breeding sites and their spatial relationship to the most recently maintained or repaired portion of the habitat.

\section{Macro-Invertebrate Monitoring}

Qualified biologist(s) will collect macro-invertebrate species presence data through D-frame dip-net point sampling in each of the "Section-3-designated" areas starting in the Year 2000 and ending in the Year 2004. These dip-net samples would be taken within 30 days prior to maintenance activities, and between thirty and sixty days after the maintenance activity. Subsequent macro-invertebrate sampling would occur annually in late spring. A control location would be determined by choosing a particular 
section of the Arroyo Las Positas for sampling that would not be disturbed until the final (fifth) year. All macro-invertebrates would be collected, identified to family or genus, and mapped to the specific sampling locations.

\section{Vegetation Re-establishment:}

Wetland vegetation within the Arroyo Las Positas channel would be identified to genus and/or species in each of the "Section-3-designated" areas and section photographs would be taken prior to and after the initial maintenance activity. Vegetative colonization in the Section-3-repaired areas will be photographed annually in late spring from the same vantage point for the following 4 years and identified to genus and/or species. 
Arroyo Las Positas Maintenance Impact Study

\section{APPENDIX B}


Arroyo Las Positas Maintenance Impact Study Invertebrates Found

\begin{tabular}{|c|c|c|c|c|c|c|c|}
\hline Family & Site & & & & & & \\
\hline & $\begin{array}{l}\text { Zone 3E, } \\
\text { 15June00 }\end{array}$ & $\begin{array}{l}\text { Zone 3E, } \\
\text { 31July00 }\end{array}$ & $\begin{array}{l}\text { Zone 3E, } \\
2 \text { Oct } 00\end{array}$ & $\begin{array}{l}\text { Zone 3E, } \\
\text { 14June01 }\end{array}$ & $\begin{array}{l}\text { Zone 3E, } \\
19 \text { Oct } 01\end{array}$ & $\begin{array}{l}\text { Zone 3E, } \\
28 \mathrm{Aug} 03\end{array}$ & $\begin{array}{l}\text { Zone 3E, } \\
\text { 18Aug05 }\end{array}$ \\
\hline Aeshnidae & & & & no sample & 3 & & \\
\hline Astacidae & & & & & & & 35 \\
\hline Belostomatidae & 5 & & & & & & 1 \\
\hline Blephaceridae & & 1 & & & & & \\
\hline Chaoboridae & & 11 & & & & & 51 \\
\hline Coenagrionidae & 9 & & & & & 152 & \\
\hline Corixidae & 4 & & & & 3 & 60 & \\
\hline Daphniidae & & & & & & & \\
\hline Ditiscidae & 5 & & & & & 20 & \\
\hline Gammaridae & 6 & & & & & 52 & \\
\hline Gomphidae & & & & & & 12 & \\
\hline Haliplidae & 1 & & & & & & \\
\hline Hydrophilidae & 3 & & & & & 16 & \\
\hline Hydropsychidae & & & & & & & \\
\hline Libellulidae & & & & & 6 & & \\
\hline Lynceidae & & 59 & 100 & & & & \\
\hline Physidae & 5 & 7 & & & & & \\
\hline Planorbidae & 17 & & & & & & \\
\hline Ptychopteridae & & 17 & & & & & \\
\hline Simulidae & 3 & & & & & & \\
\hline Trichorithidae & 4 & & 1 & & & & \\
\hline
\end{tabular}


Arroyo Las Positas Maintenance Impact Study Invertebrates Found

\begin{tabular}{|c|c|c|c|c|c|c|c|}
\hline & $\begin{array}{l}\text { Zone 3F, } \\
\text { 15June00 }\end{array}$ & $\begin{array}{l}\text { Zone 3F, } \\
\text { 31July00 }\end{array}$ & $\begin{array}{l}\text { Zone } \\
3 \mathrm{~F}, 20 \text { Oct00 }\end{array}$ & $\begin{array}{l}\text { Zone 3F } \\
\text {,14June 01 }\end{array}$ & $\begin{array}{l}\text { Zone 3F } \\
\text {,19Oct01 }\end{array}$ & $\begin{array}{l}\text { Zone 3F } \\
\text { 28Aug03 }\end{array}$ & $\begin{array}{l}\text { Zone 3F } \\
\text { 18Aug05 }\end{array}$ \\
\hline \multicolumn{8}{|l|}{ Aeshnidae } \\
\hline Belostomatidae & 3 & & & & & 1 & \\
\hline \multicolumn{8}{|l|}{ Blephaceridae } \\
\hline \multicolumn{8}{|l|}{ Chaoboridae } \\
\hline Chironomidae & & & & & & & 18 \\
\hline Coenagrionidae & 4 & & 2 & 9 & & & 5 \\
\hline Corixidae & 2 & 3 & & & 5 & 4 & \\
\hline \multicolumn{8}{|l|}{ Daphniidae } \\
\hline Ditiscidae & 1 & 4 & & 1 & 1 & 12 & \\
\hline Gammaridae & 21 & 2 & & 2 & & & 29 \\
\hline Gomphidae & 6 & 2 & & & & 1 & 4 \\
\hline \multicolumn{8}{|l|}{ Haliplidae } \\
\hline Hydrophilidae & & 1 & & & & & \\
\hline Hydropsychidae & & 1 & 2 & & & 2 & \\
\hline \multicolumn{8}{|l|}{ Libellulidae } \\
\hline Lynceidae & & & 30 & & & & \\
\hline Physidae & & 2 & 15 & 10 & 25 & 31 & 18 \\
\hline Planorbidae & 1 & 7 & 6 & 1 & & 8 & 25 \\
\hline \multicolumn{8}{|l|}{ Ptychopteridae } \\
\hline \multicolumn{8}{|l|}{ Simulidae } \\
\hline Sminthuridae & 1 & & & & & & \\
\hline Trichorithidae & 15 & 50 & 2 & 4 & & 43 & \\
\hline
\end{tabular}


Arroyo Las Positas Maintenance Impact Study Invertebrates Found

\begin{tabular}{|c|c|c|c|c|c|c|c|}
\hline & $\begin{array}{l}\text { Zone 3G, } \\
\text { 15June00 }\end{array}$ & $\begin{array}{l}\text { Zone 3G, } \\
\text { 31 July00 }\end{array}$ & $\begin{array}{l}\text { Zone } 3 \mathrm{G}, \\
20 \operatorname{Oct} 00\end{array}$ & $\begin{array}{l}\text { Zone 3G, } \\
\text { 14June01 }\end{array}$ & $\begin{array}{l}\text { Zone } 3 \mathrm{G}, \\
190 \mathrm{ct} 01\end{array}$ & $\begin{array}{l}\text { Zone 3G, } \\
\text { 28Aug03 }\end{array}$ & $\begin{array}{l}\text { Zone 3G, } \\
\text { 18Aug05 }\end{array}$ \\
\hline Aeshnidae & & & & & 2 & & 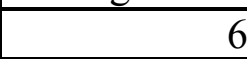 \\
\hline Belostomatidae & & & 6 & & 5 & 7 & \\
\hline Blephaceridae & 11 & & & 11 & & & \\
\hline Canacidae & & & & 1 & & 2 & \\
\hline Chaoboridae & 2 & & & & & & \\
\hline Coenagrionidae & 2 & 3 & 6 & 13 & 7 & & \\
\hline Corixidae & & & & & & 7 & \\
\hline Chrysomelidae & & & 1 & & & & \\
\hline Daphniidae & & 1 & & & & & \\
\hline Ditiscidae & 11 & & 2 & 2 & & 21 & \\
\hline Gammaridae & 40 & 3 & 8 & & & & \\
\hline Gomphidae & & & & & & 4 & 12 \\
\hline \multicolumn{8}{|l|}{ Haliplidae } \\
\hline Hydrophilidae & & & & & 6 & & 21 \\
\hline \multicolumn{2}{|l|}{ Hydrophantoidea } & & 1 & & & & \\
\hline Hydropsychidae & & & 1 & & & & 7 \\
\hline Libellulidae & & & & 4 & 13 & 21 & \\
\hline Lynceidae & & 95 & 10 & & 15 & 3 & 67 \\
\hline Physidae & 10 & 13 & 5 & 19 & 20 & 10 & 15 \\
\hline Planorbidae & & 3 & 12 & 11 & 12 & & 9 \\
\hline \multicolumn{8}{|l|}{ Ptychopteridae } \\
\hline \multicolumn{8}{|l|}{ Simulidae } \\
\hline Stratiomyidae & & & & 1 & & 8 & \\
\hline Trichorithidae & 7 & 1 & 3 & 10 & 4 & 11 & \\
\hline
\end{tabular}


Arroyo Las Positas Maintenance Impact Study Invertebrates Found

\begin{tabular}{|c|c|c|c|c|c|c|c|}
\hline & $\begin{array}{l}\text { Zone } 3 \mathrm{H}, \\
\text { 15June00 }\end{array}$ & $\begin{array}{l}\text { Zone 3H, } \\
\text { 31July00 }\end{array}$ & $\begin{array}{l}\text { Zone } 3 \mathrm{H}, \\
20 \mathrm{Oct} 00\end{array}$ & $\begin{array}{l}\text { Zone } 3 \mathrm{H}, \\
\text { 14June01 }\end{array}$ & $\begin{array}{l}\text { Zone 3H, } \\
19 \text { Oct } 01\end{array}$ & $\begin{array}{l}\text { Zone } 3 \mathrm{H}, \\
28 \mathrm{Aug} 03\end{array}$ & $\begin{array}{l}\text { Zone 3H, } \\
18 \mathrm{Aug} 05\end{array}$ \\
\hline Aeshnidae & & & & 2 & no sample & no sample & \\
\hline Astacidae & & & & & & & 6 \\
\hline Belostomatidae & 1 & & 2 & & & & \\
\hline Blephaceridae & & & 2 & 15 & & & \\
\hline Chaoboridae & & & 3 & & & & \\
\hline \multicolumn{8}{|l|}{ Chironomidae } \\
\hline Coenagrionidae & 8 & & 2 & 49 & & & 91 \\
\hline Corixidae & & & & 1 & & & \\
\hline \multicolumn{8}{|l|}{ Daphniidae } \\
\hline Ditiscidae & & & & 2 & & & \\
\hline Gammaridae & 7 & 5 & 32 & 3 & & & 53 \\
\hline Gomphidae & 1 & 2 & & & & & 3 \\
\hline \multicolumn{8}{|l|}{ Haliplidae } \\
\hline Hydrophilidae & 1 & 1 & & & & & 1 \\
\hline Hydropsychidae & & & & & & & 5 \\
\hline Libellulidae & & & & 2 & & & 44 \\
\hline Lynceidae & & 56 & & & & & \\
\hline Physidae & 3 & 3 & 2 & 8 & & & 9 \\
\hline Planorbidae & 18 & 5 & 13 & 4 & & & 2 \\
\hline \multicolumn{8}{|l|}{ Ptychopteridae } \\
\hline \multicolumn{8}{|l|}{ Simulidae } \\
\hline Trichorithidae & & & 1 & 16 & & & 12 \\
\hline
\end{tabular}


Arroyo Las Positas Maintenance Impact Study Invertebrates Found

\begin{tabular}{|c|c|c|c|c|c|c|c|}
\hline & $\begin{array}{l}\text { Zone IH, } 15 \\
\text { June } 00\end{array}$ & $\begin{array}{l}\text { Zone IH, } 31 \\
\text { July } 00\end{array}$ & $\begin{array}{l}\text { Zone IH, } 2 \\
\text { Oct } 00\end{array}$ & $\begin{array}{l}\text { Zone IH, } \\
\text { 14june } 01\end{array}$ & $\begin{array}{l}\text { Zone IH, } \\
19 \text { Oct01 }\end{array}$ & $\begin{array}{l}\text { Zone IH, } \\
28 \text { Aug03 }\end{array}$ & $\begin{array}{l}\text { Zone IH, } \\
\text { 18Aug05 }\end{array}$ \\
\hline Aeshnidae & & & & 2 & & & \\
\hline Belostomatidae & 5 & & 2 & & & & 1 \\
\hline Blephaceridae & & & & 6 & & & \\
\hline Chaoboridae & & 3 & 3 & & & 16 & \\
\hline Chironomidae & & & & & & & 9 \\
\hline Coenagrionidae & 22 & 3 & 3 & 11 & 4 & 9 & 1 \\
\hline \multicolumn{8}{|l|}{ Corixidae } \\
\hline \multicolumn{8}{|l|}{ Daphniidae } \\
\hline Ditiscidae & 4 & & & 5 & 10 & 2 & \\
\hline Gammaridae & 2 & 4 & 2 & 35 & 29 & 12 & 91 \\
\hline \multicolumn{8}{|l|}{ Gomphidae } \\
\hline Haliplidae & 6 & & & & & & \\
\hline Hydrophilidae & & & & 3 & 6 & 2 & 4 \\
\hline Hydropsychidae & & & & & & & 11 \\
\hline Libellulidae & & & & 6 & 1 & & 2 \\
\hline Lynceidae & & 35 & & & & 51 & \\
\hline Physidae & & 3 & 1 & 11 & & 11 & \\
\hline Planorbidae & 13 & 2 & 2 & 3 & 7 & 2 & \\
\hline \multicolumn{8}{|l|}{ Ptychopteridae } \\
\hline \multicolumn{8}{|l|}{ Simulidae } \\
\hline Trichorithidae & 3 & 2 & 3 & 5 & 2 & 5 & 2 \\
\hline
\end{tabular}




\begin{tabular}{|c|c|c|c|c|c|c|c|}
\hline \multicolumn{8}{|c|}{$\begin{array}{l}\text { Number of Families } \\
\text { Represented by Zone }\end{array}$} \\
\hline & 15-Jun-00 & 31-Jul-00 & $2-O c t-00$ & 14-Jun-01 & 19-Oct-01 & 28-Aug-03 & 18-Aug-05 \\
\hline Zone IH & 7 & 7 & 7 & 10 & 7 & 9 & 8 \\
\hline Zone 3E & 11 & 5 & 2 & & 3 & 6 & 3 \\
\hline Zone 3F & 9 & 9 & 6 & 6 & 3 & 8 & 6 \\
\hline Zone 3G & 7 & 7 & 11 & 9 & 9 & 10 & 7 \\
\hline Zone 3H & 7 & 6 & 8 & 10 & & & 10 \\
\hline & & & & & & & \\
\hline \multicolumn{8}{|c|}{ Abundance by Zone } \\
\hline & 15-Jun-00 & 31-Jul-00 & 2-Oct-00 & 14-Jun-01 & 19-Oct-01 & 28-Aug-03 & 18-Aug-05 \\
\hline Zone IH & 55 & 52 & 16 & 87 & 59 & 110 & 121 \\
\hline Zone 3E & 62 & 95 & 101 & & 12 & 312 & 87 \\
\hline Zone 3F & 54 & 72 & 57 & 27 & 31 & 102 & 99 \\
\hline Zone 3G & 83 & 119 & 55 & 72 & 84 & 94 & 137 \\
\hline Zone 3H & 39 & 72 & 57 & 102 & & & 226 \\
\hline
\end{tabular}


Complete list of Aquatic Invertebrates sampled in both control and dredged sites. (Updated October 2005.)

Order-Amphipoda

Family-Gammaridae Genus-Gammarus

Order-Branchiopoda

Family-Lynceidae Genus-Lynceus

Order-Cladocera

Family-Daphniidae Genus-Daphnia

Order- Collembola

Family-Sminthuridae

Order-Coleoptera

Family-Ditiscidae

Family-Haliplidae

Family-Hydrophilidae

Family-Chrysomellidae

Order-Decapoda

Family-Astacidae

Order-Diptera

Family-Blephaceridae

Family-Chaoboridae

Family-Ptychopteridae

Family-Simulidae

Family-Chironomidae

Family-Stratiomyidae

Order-Ephemeroptera

Family-Tricorythidae

Order-Gastropoda

Family-Planorbidae

Family-Physidae

Order-Hemiptera

Sub-Order-Heteroptera

Family-Corixidae

Family-Belostomatidae 
Order-Odonata

Sub-order-Anisoptera

Family-Gomphidae

Family-Aeshnidae

Family-Libellulidae

Sub-order-Zygoptera

Family-Coenagrionidae

Order-Trichoptera

Family-Hydropsychidae 